\title{
EVALUASI POTENSI FUNGSI TANAMAN SEBAGAI PENYERAP POLUTAN GAS CO2 PADA LANSKAP JALAN REGIONAL RING ROAD KOTA BOGOR
}

\section{DITYA ANGGORO AJI}

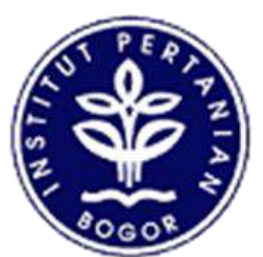

\author{
DEPARTEMEN ARSITEKTUR LANSKAP \\ FAKULTAS PERTANIAN \\ INSTITUT PERTANIAN BOGOR \\ BOGOR \\ 2018
}





\section{PERNYATAAN MENGENAI SKRIPSI DAN SUMBER INFORMASI SERTA PELIMPAHAN HAK CIPTA*}

Dengan ini saya menyatakan bahwa skripsi berjudul evaluasi potensi fungsi tanaman sebagai penyerap polutan gas pada lanskap jalan Regional Ring Road Kota Bogor adalah benar karya saya dengan arahan dari komisi pembimbing dan belum diajukan dalam bentuk apa pun kepada perguruan tinggi mana pun. Sumber informasi yang berasal atau dikutip dari karya yang diterbitkan maupun tidak diterbitkan dari penulis lain telah disebutkan dalam teks dan dicantumkan dalam Daftar Pustaka di bagian akhir skripsi ini.

Dengan ini saya melimpahkan hak cipta dari karya tulis saya kepada Institut Pertanian Bogor.

Bogor September 2018

Ditya Anggoro Aji

NIM A44120087 


\begin{abstract}
ABSTRAK
DITYA ANGGORO AJI. Evaluasi potensi Fungsi Tanaman Sebagai Penyerap Polutan Gas CO2 pada Lanskap Regional Ring Road Kota Bogor. Dibimbing oleh BAMBANG SULISTYANTARA.

Lanskap jalan merupakan fasilitas penunjang untuk para pengendara motor. Aktifitas pada lanskap jalan tidak lepas dari penggunaan kendaraan. Pembakaran bahan bakar pada kendaraan menyebabkan terjadinya pencemaran udara karena menghasilkan zat pencemar udara salah satunya yaitu karbon monoksida (Wardhana, 2001). Emisi CO2 yang tidak terkontrol oleh vegetasi dapat mengakibat suhu permukaan bumi meningkat atau disebut pemanasan global. Vegetasi diketahui dapat menyerap polutan gas CO2. Jalan R3 Kota Bogor sudah ditanam vegetasi sepanjang jalan dan memiliki potensi sebagai vegetasi penyerap polutan gas CO2. Dari hasil analisis yang telah dilakukan, sisa emisi CO2 yang terhitung di sepanjang jalan R3 sebesar 3642,413 kg/ha/jam. Dapat disimpulkan bahwa untuk saat ini vegetasi yang tertanam pada jalan R3 bekum cukup untuk mereduksi emisi CO2 yang dihasilkan oleh kendaraan. Sehingga jalan R3 membutuhkan penanaman jenis pohon dengan kemampuan serapan CO2 yang tinggi dan juga memanfaatkan ruang tanam yang ada di sepanjang jalan R3 Kota Bogor.
\end{abstract}

Kata kunci: Emisi CO2, Polusi udara, Potensi menyerap CO2, Lanskap jalan, Vegetasi

\title{
ABSTRACT
}

DITYA ANGGORO AJI. Potential Evaluation of Plant Function as CO2 Pollutan Absorbtion at Regional Ring Road Bogor City Streetscape. Supervised by BAMBANG SULISTYANTARA.

Streetscape is a support system for both vehicles and pedestrians. Activities in the street cannot be separated with the use of vehicles. Burning fuel in the vehicles causing air pollution due to produce contaminants air one, of them is carbon monoxide (wardhana,2011). CO2 emissions that cannot be controlled by vegetation can making temperature in the surface increasing referred as global warming. R3 Road Bogor City has been planted and has the potential as a vegetation for $\mathrm{CO} 2$ pollutant gas absorption. From the analysis results, the remaining $\mathrm{CO} 2$ emissions calculated along R3 road are $3642,413 \mathrm{~kg} / \mathrm{ha} /$ hour. It can be concluded that for the time being the existing vegetation in $\mathrm{R} 3 \mathrm{road}$ is not enough to reduce $\mathrm{CO} 2$ emissions that produced by vehicles. So that $\mathrm{R} 3$ road need some tree species with high $\mathrm{CO} 2$ absorption capability and also utilizes the planting space along the R3 Road of Bogor City.

Keywords: Air pollution, CO2 emissions, Streetscape, Plant for absorbing gaseous pollutants, Vegetation 


\title{
EVALUASI POTENSI FUNGSI TANAMAN SEBAGAI PENYERAP POLUTAN GAS CO2 PADA LANSKAP JALAN REGIONAL RING ROAD KOTA BOGOR
}

\section{DITYA ANGGORO AJI}

\author{
Skripsi \\ sebagai salah satu syarat untuk memperoleh gelar \\ Sarjana Pertanian/Arsitektur Lanskap \\ pada \\ Departemen Arsitektur Lanskap
}

\author{
DEPARTEMEN ARSITEKTUR LANSKAP \\ FAKULTAS PERTANIAN \\ INSTITUT PERTANIAN BOGOR \\ BOGOR \\ 2018
}


(C) Hak Cipta Milik IPB, Tahun 2018

Hak Cipta Dilindungi Undang-Undang

Dilarang mengutip sebagian atau seluruh karya tulis ini tanpa mencatumkan atau menyebutkan sumbernya. Pengutipan hanya untuk kepentingan pendidikan, penelitian, penulisan karya tulis ilmiah, penyusunan laporan, penulisan kritik, atau tinjauan suatu masalah; dan pengutipan tersebut tidak merugikan kepentingan $I P B$.

Dilarang mengumumkan dan memperbannyak sebagian atau seluruh karya tulis ini dalam bentuk apapun tanpa izin IPB 
Judul Skripsi: Evaluasi Potensi Fungsi Tanaman Sebagai Penyerap Polutan Gas CO2 pada Lanskap Jalan Regional Ring Road Kota Bogor

Nama : Ditya Anggoro Aji

NIM : A44120087

Disetujui oleh

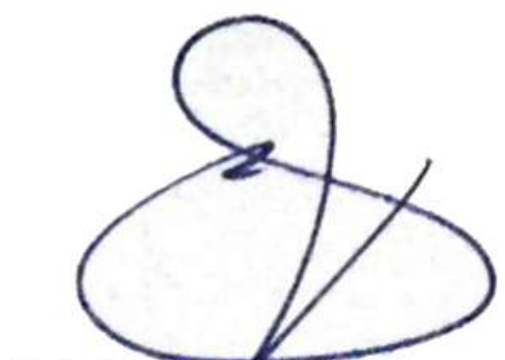

Dr.Ir.Bambang Sulistyantara, M.Agr

Pembimbing

Diketahui oleh

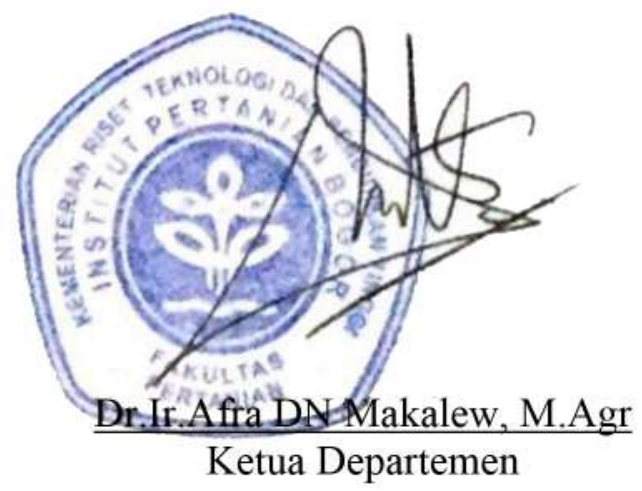

Tanggal Lulus: 07 SEP 2018 



\section{PRAKATA}

Puji syukur penulis panjatkan kehadirat Allah subhanahu wa ta'ala, karena atas karunia dan rahmat-NYA sehingga penelitian yang berjudul Evaluasi potensi fungsi tanaman sebagai penyerap polutan gas $\mathrm{CO} 2$ pada lanskap Jalan Regional Ring Road Kota Bogor dapat terselesaikan dengan baik.

Terima kasih penulis ucapkan kepada Bapak Dr.Ir.Bambang Sulistyantara, M.Agr selaku pembimbing skripsi yang telah memberikan arahan, saran, dorongan, serta nasehat kepada penulis untuk menyelesaikan penelitian. Penulis juga berterima kasih kepada keluarga yang telah memberikan dorongan serta nasehat dan semua teman-teman yang turut membantu dalam menyelesaikan penelitian ini.

Hasil penelitian diharapkan dapat dimanfaatkan menjadi masukan dan wawasan baru bagi arsitektur lanskap, pemertintah serta dinas-dinas terkait, dan masyarakat yang sadar akan pentingnya potensi tanaman sebagai penyerap polutan gas $\mathrm{CO} 2$. Penulis sadar bahwa penelitian ini masih banyak kekurangan dan belum sempurna. Oleh karena itu, penulis sangat mengharapkan masukan untuk menyempurnakan manfaat dari penelitian ini

Bogor, September 2018

Ditya Anggoro Aji 



\section{DAFTAR ISI}

DAFTAR TABEL

DAFTAR GAMBAR i

DAFTAR LAMPIRAN

PENDAHULUAN 1

Latar Belakang $\quad 1$

Tujuan Penelitian 2

Manfaat Penelitian 2

Kerangka Pikir Penelitian $\quad 2$

TINJAUAN PUSTAKA 3

Evaluasi $\quad 3$

Lanskap Jalan 3

Jalur Hijau

$\begin{array}{ll}\text { Pencemaran Udara } & 6\end{array}$

$\begin{array}{ll}\text { Polutan } \mathrm{CO} 2 & 7\end{array}$

Fungsi Ekologis Tanaman Dalam Lanskap $\quad 8$

Fungsi Tanaman Sebagai Penyerap Polutan Gas 8

$\begin{array}{lr}\text { METODOLOGI } & 10\end{array}$

$\begin{array}{ll}\text { Lokasi dan Waktu Penelitian } & 10\end{array}$

$\begin{array}{ll}\text { Alat dan Bahan } & 10\end{array}$

Metode Penelitisn 11

Tahap Persiapan 11

Tahap Inventarisasi 11

Tahap Analisis Spasial 12

Tahap Analisis Deskriptif 14

$\begin{array}{ll}\text { Tahap Sintesis } & 17\end{array}$

$\begin{array}{lr}\text { KONDISI UMUM } & 18\end{array}$

$\begin{array}{lr}\text { Sejarah Kawasan } & 18\end{array}$

Letak, Luas, dan Aksesbilitas 18

Topografi dan Kemiringan Lahan 19

Tata Guna Lahan $\quad 20$

Iklim 21

Tanah 22

Vegetasi 23

Jalan R3 Kota Bogor 24

Lokasi dan Dimensi $\quad 24$

Elemen Pembentuk Jalan $\quad 25$

Tata Hijau Jalan $\quad 25$

Jumlah Kendaraan $\quad 26$

PEMBAHASAN $\quad 27$

Lanskap jalan R3 Kota Bogor $\quad 27$

Identifikasi Karakteristik Jalur Hijau Jalan 28

Jalur Tanaman Tepi Jalan $\quad 29$

Median Jalan $\quad 29$

$\begin{array}{ll}\text { Traffic Islands (pulau jalan) } & 30\end{array}$

Identifikasi Vegetasi Jalur Hijau Jalan $\quad 31$ 
Jenis Pohon di Jalan R3 Kota Bogor

Fungsi Ekologis Pohon Sebagai Penyerap Polutan 49

Analisis Emisi CO2 Jalur Hijau Jalan 49

Jumlah Kendaraan $\quad 49$

Emisi CO2 $\quad 50$

Vegetasi Sebagai Penyerap CO2 51

Sisa Emisi CO2 di Jalan R3 Kota Bogor 52

Evaluasi Fungsi Ekologis Penyerap Polutan Gas 53

Rekomendasi $\quad 58$

Segmen Terbaik $\quad 58$

Vegetasi Sebagai Penyerap Polutan Gas Pada Jalan R3 59

Rekomendasi Jenis Tanaman $\quad 61$

Rekomendasi Penanaman 63

SIMPULAN DAN SARAN

$\begin{array}{ll}\text { Simpulan } & 79\end{array}$

$\begin{array}{ll}\text { Saran } & 79\end{array}$

DAFTAR PUSTAKA $\quad 80$

LAMPIRAN $\quad 82$

RIWAYAT HIDUP 


\section{DAFTAR TABEL}

Tabel 1 Toksisitas Relatif Polutan Udara 6

Tabel 2 Baku Mutu Udara Ambien $\quad 7$

Tabel 3 Jenis, Parameter, Bentuk dan Sumber Data 11

Tabel 4 Faktor Emisi Kendaraan Bermotor Bersadarkan Tipe Bahan Bakar 11

Tabel 5 Konsumsi Energi Spesifik Kendaraan Bermotor 13

Tabel 6 Kriteria Penilaian Fungsi Ekologis 14

Tabel 7 Pengelompokan Persentase Pembobotan Aspek Fungsi Jalur Hijau Jalan 15

Tabel 8 Evaluasi Menggunakan Metode KPI (Key Performance Index) 15

Tabel 9 Ketinggian Lahan di Kelurahan-Kelurahan Sepanjang Jalan R3

Kota Bogor

Tabel 10 Kemiringin Lahan di Kelurahan-Kelurahan Sepanjang Jalan R3

Kota Bogor 20

Tabel 11 Data Iklim Kota Bogor Tahun $2016 \quad 21$

Tabel 12 Kepekaan Tanah Terhadap Erosi di Kelurahan Sepanjang Jalan R3

Kota Bogor $\quad 22$

Tabel 13 Tekstur Tanah di Kelurahan Sepanjang Jalan R3 Kota Bogor 23

Tabel 14 Jumlah Kendaraan di Kota Bogor 26

Tabel 15 Jenis dan Letak Pohon Pada Segmen 1 Jalur Hijau Jalan R3 Kota Bogor 32

Tabel 16 Jenis dan Letak Pohon Pada Segmen 2 Jalur Hijau Jalan R3 Kota Bogor 34

Tabel 17 Jenis dan Letak Pohon Pada Segmen 3 Jalur Hijau Jalan R3 Kota Bogor 36

Tabel 18 Jenis dan Letak Pohon Pada Segmen 4 Jalur Hijau Jalan R3 Kota Bogor 38

Tabel 19 Jenis dan Letak Pohon Pada Segmen 5 Jalur Hijau Jalan R3 Kota Bogor 40

Tabel 20 Jenis dan Letak Pohon Pada Segmen 6 Jalur Hijau Jalan R3 Kota Bogor 42

Tabel 21 Jenis dan Letak Pohon Pada Segmen 7 Jalur Hijau Jalan R3 Kota Bogor 44

Tabel 22 Jenis dan Letak Pohon Pada Segmen 8 Jalur Hijau Jalan R3 Kota Bogor 46

Tabel 23 Jenis dan Letak Pohon Pada Segmen 9 Jalur Hijau Jalan R3 Kota Bogor 46

Tabel 24 Tingkat Serapan Karbon Dioksida (CO2) Beberapa Pohon di Jalan R3

Kota Bogor 49

Tabel 25 Jumlah Maks dan Min Kendaraan per Jam di Jalan R3 Kota Bogor $\quad 50$

Tabel 26 Luas Tutupan Vegetasi per Segmen $\quad 52$

Tabel 27 Evaluasi Fungsi Tanaman Menyerap Polutan Gas 54

Tabel 28 Hasil Evaluasi Kesesuaian Pohon Sebagai Penyerap Polutan Gas 57

Tabel 29 Jenis Pohon Kategori Sangat Sesuai dan Sesuai pada Segmen $6 \quad 61$

Tabel 30 Nilai Serapan CO2 pada Segmen $6 \quad 62$

Tabel 31 Perlakuan Vegetasi pada Median Segmen 6

\section{DAFTAR GAMBAR}

Gambar 1 Kerangka Pemikiran Evaluasi Fungsi Ekologis pada Lanskap Jalan R3 Kota Bogor

Gambar 2 Tata Letak Tanaman pada Jalur Hijau

Gambar 3 Tanaman Menjernihkan Udara

Gambar 4 Peta Kota Bogor \& Peta Jalan R3 Kota Bogor 
Gambar 5 Ilustrasi Persentase Total Cahaya yang Diblokir Oleh Pepohonan 15

Gambar 6 Kombinasi Penanaman Vegetasi pada Median Jalan 16

Gambar 7 Kelurahan-Kelurahan yang Dilewati Jalan R3 Kota Bogor 19

Gambar 8 Ilustrasi Dimensi Jalan R3 Kota Bogor Dengan Lebar Median 1m 24

Gambar 9 Ilustrasi Dimensi Jalan R3 Kota Bogor Dengan Lebar Median 12m 24

Gambar 10 Ilustrasi Dimensi Jalan R3 Kota Bogor Dengan Lebar Median 3m 24

Gambar 11 (a) Lampu jalan, dan (b) Perkerasan 25

Gambar 12 Tata Hijau Jalan R3 Kota Bogor 25

Gambar 13 Pola Penanaman Groundcover di Median Jalan 26

Gambar 14 Kondisi Lalu Lintas Padat Menuju Perempatan Jambu Dua 27

Gambar 15 (a) Penanaman Vegetasi Rapat, dan (b) Ruang Terbuka Hijau di

Salah Satu Median 28

Gambar 16 Pohon pada Tepi Jalan 29

Gambar 17 (a) Median Dengan Kombinasi Pohon, Perdu, Semak, Groundcover, dan Rumput, dan (b) Median dengan kombinasi Pohon, Perdu dan Rumput $\quad 30$

Gambar 18 Perkerasan Pada Median Jalan R3 Kota Bogor 30

Gambar 19 Pulau Jalan Pada Jalan R3 Kota Bogor 30

Gambar 20 Peta Sebaran Pohon Jalan R3 Kota Bogor (Segmen 1) 33

Gambar 21 Peta Sebaran Pohon Jalan R3 Kota Bogor (Segmen 2) 35

Gambar 22 Peta Sebaran Pohon Jalan R3 Kota Bogor (Segmen 3) 37

Gambar 23 Peta Sebaran Pohon Jalan R3 Kota Bogor (Segmen 4) 39

Gambar 24 Peta Sebaran Pohon Jalan R3 Kota Bogor (Segmen 5) 41

Gambar 25 Peta Sebaran Pohon Jalan R3 Kota Bogor (Segmen 6) 43

Gambar 26 Peta Sebaran Pohon Jalan R3 Kota Bogor (Segmen 7) 45

Gambar 27 Peta Sebaran Pohon Jalan R3 Kota Bogor (Segmen 8) 47

Gambar 28 Peta Sebaran Pohon Jalan R3 Kota Bogor (Segmen 9) 48

Gambar 29 Peta Emisi CO2 di Jalan R3 Kota Bogor $\quad 50$

Gambar 30 Peta Serapan CO2 di Jalan R3 Kota Bogor 51

Gambar 31 Peta Sisa Emisi CO2 di Jalan R3 Kota Bogor 52

Gambar 32 Evaluasi Fungsi Tanaman Sebagai Penyerap Polutan Gas pada Jalan

R3 Kota Bogor dengan Metode KPI 55

Gambar 33 Foto Kondisi Penanaman di Segmen $6 \quad 58$

Gambar 34 Jalur Hijau Jalan Untuk Menyerap Polusi Udara 61

Gambar 35 Peta Rekomendasi Segmen 6 (Bagian 1) 64

Gambar 36 Peta Rekomendasi Segmen 6 (Bagian 2) 65

Gambar 37 Peta Rekomendasi Segmen 6 (Bagian 3) 66

Gambar 38 Peta Rekomendasi Segmen 6 (Bagian 4) 67

Gambar 39 Peta Rekomendasi Segmen 6 (Bagian 5) 68

Gambar 40 Peta Rekomendasi Segmen 6 (Bagian 6) 69

Gambar 41 Peta Rekomendasi Segmen 6 (Bagian 7) 70

Gambar 42 Peta Rekomendasi Segmen 6 (Bagian 8) 71

Gambar 43 Peta Rekomendasi Segmen 6 (Bagian 9) 72

Gambar 44 Peta Rekomendasi Segmen 6 (Bagian 10) 73

Gambar 45 Peta Rekomendasi Segmen 6 (Bagian 11) $\quad 74$

Gambar 46 Peta Rekomendasi Segmen 6 (Bagian 12) 75

Gambar 47 Peta Rekomendasi Segmen 6 (Bagian 13) 76 
Gambar 48 Peta Rekomendasi Segmen 6 (Bagian 14) 77

Gambar 49 Peta Rekomendasi Segmen 6 (Bagian 15)

\section{DAFTAR LAMPIRAN}

Lampiran 1 Jenis, Letak, dan Jumlah Pohon pada Jalur Hijau Jalan R3 Kota Bogor

Lampiran 2 Peta Sebaran Pohon di Jalan R3 Kota Bogor

Lampiran 3 Elemen Tanaman pada Jalur Hijau Jalan R3 Kota Bogor

Lampiran 4 Jenis Tanaman yang Berpotensi Menyerap NO2

86

Lampiran 5 Daya Serap Pohon Terhadap Karbon Dioksida

90 



\section{PENDAHULUAN}

\section{Latar Belakang}

Lanskap jalan merupakan fasilitas penunjang untuk para pengendara motor serta pejalan kaki. Lanskap jalan adalah wajah dari karakter lahan atau tapak yang terbentuk pada lingkungan jalan, baik yang terbentuk dari elemen lanskap alam seperti bentuk topografi lahan maupun yang terbentuk dari elemen lanskap buatan manusia yang disesuaikan dengan kondisi lahannya (Direktorat Jenderal Bina Marga, 1996). Lanskap jalan berperan penting dalam membangun karakter lingkungan, spasial, dan visual agar dapat memberikan suatu identitas perkotaan (Simonds, 1983). Tanaman pada lanskap jalan berfungsi sebagai pengontrol pandangan, pembatas fisik, pengendali iklim, pencegah erosi, habitat satwa, dan estetika (Carpenter et al, 1975).

Kota Bogor merupakan kota yang dikenal sebagai kota wisata. Padatnya kota bogor dipengaruhi oleh jumlah kendaraan semakin bertambah akibat kunjungan masyarakat dari kota lain. Menurut Badan Pusat Statistik Kota Bogor jumlah kendaraan di Kota Bogor pada tahun 2017 naik 20\% dibandingkan tahun 2014. Salah satu sektor jalanan yang dominan padat di Kota Bogor adalah Jalan Raya Padjajaran. Sedangkan Jalan R3 Kota Bogor merupakan jalan yang membentang sejajar dengan Jalan Raya Padajajaran, sehingga banyak masyarakat menggunakan akses Jalan R3 Kota Bogor untuk jalan alternatif.

Semakin banyak jumlah kendaraan maka semakin banyak juga jumlah polusi yang dihasilkan oleh kendaraan bermotor. Karbon dioksida (CO2) merupakan salah satu hasil pembakaran bahan bakar pada kendaraan. Apabila emisi CO2 yang dihasilkan dari kendaraan ini tidak terkelola dengan baik dan melewati batas baku mutu udara ambien maka akan terjadi global warming. Vegetasi diketahui dapat menyerap emisi $\mathrm{CO} 2$ yang dihasilkan pembakaran kendaraan dan mampu menghasilkan okseigen $\left(\mathrm{O}_{2}\right)$, Sehingga dapat memaksilkan fungsi ekologis lanskap jalan terhadap hasil pembakaran kendaraan bermotor untuk meningkatkan kenyamanan pengguna jalan.

Jalan R3 Kota Bogor merupakan proyek jalan lingkar tembusan yang direncanakan oleh pemerintah untuk mengurangi kemacetan di Kota Bogor. Pembangunan Jalan R3 Kota Bogor atau bisa disebut proyek Regional Ring Road masih dalam proses pembangunan sejak tahun 2013. Sepanjang Jalan R3 Kota Bogor yang sudah terbangun pada saat ini sudah ditanam vegetasi di median jalan mapun tepi jalan. Jalan ini memiliki potensi bertambahnya jumlah kendaraan yang melintasi apabila proyek jalan sudah selesai, maka vegetasi yang terdapat di sepanjang jalan tersebut perlu dievaluasi apakah memiliki kemampuan sebagai vegetasi penyerap polutan $\mathrm{CO} 2$ akibat polusi dari pembakaran kendaraan bermotor.

\section{Tujuan Penelitian}

Tujuan dari penelitian ini adalah :

1. Mengidentifikasi jenis tanaman di sepanjang jalan R3 Kota Bogor,

2. Mencari potensi daya emisi polutan $\mathrm{CO} 2$ di lanskap Jalan R3 Kota Bogor,

3. Mengevaluasi tanaman di lanskap jalan R3 Kota Bogor sebagai fungsi penyerap polutan gas sesuai dengan standar, 
4. Memberikan rekomendasi penanaman lanskap jalan yang dapat digunakan sebagai contoh penanaman yang sesuai sebagai tanaman penyerap polutan gas $\mathrm{CO} 2$.

\section{Manfaat Penelitian}

Manfaat dari penelitian ini adalah sebagai rekomendasi bagi pemerintah daerah dalam menentukan kebijakan yang terkait dengan lanskap dalam mengoptimalkan fungsi tanaman sebagai penyerap polutan gas pada lanskap jalan untuk kenyamanan pengguna jalan.

\section{Kerangka Pikir Penelitian}

Kerangka pikir merupakan pemaparan pola pikir yang mendasari metode yang akan dilakukan di penelitian ini (Gambar 1). Pada pelaksanaannya dilakukan analisis secara spasial dan deskriptif. Analisis secara spasial dilakukan untuk mengetahui kondisi lapang serta sebaran pohon yang kemudian dibandingkan dengañ data litelatur Analisis secara deskriptif dilakukan dengan mengevaluasi jenis tanaman yang ada pada tapak yang terfokus sebagai kriteria tanaman sebagai penyerap polutan gas. Kemudiam, dari dua hasil analisis digabungkan serta diolah menjadi gambar ilustrasi jalan yang sesuai untuk menyerap polutan gas.

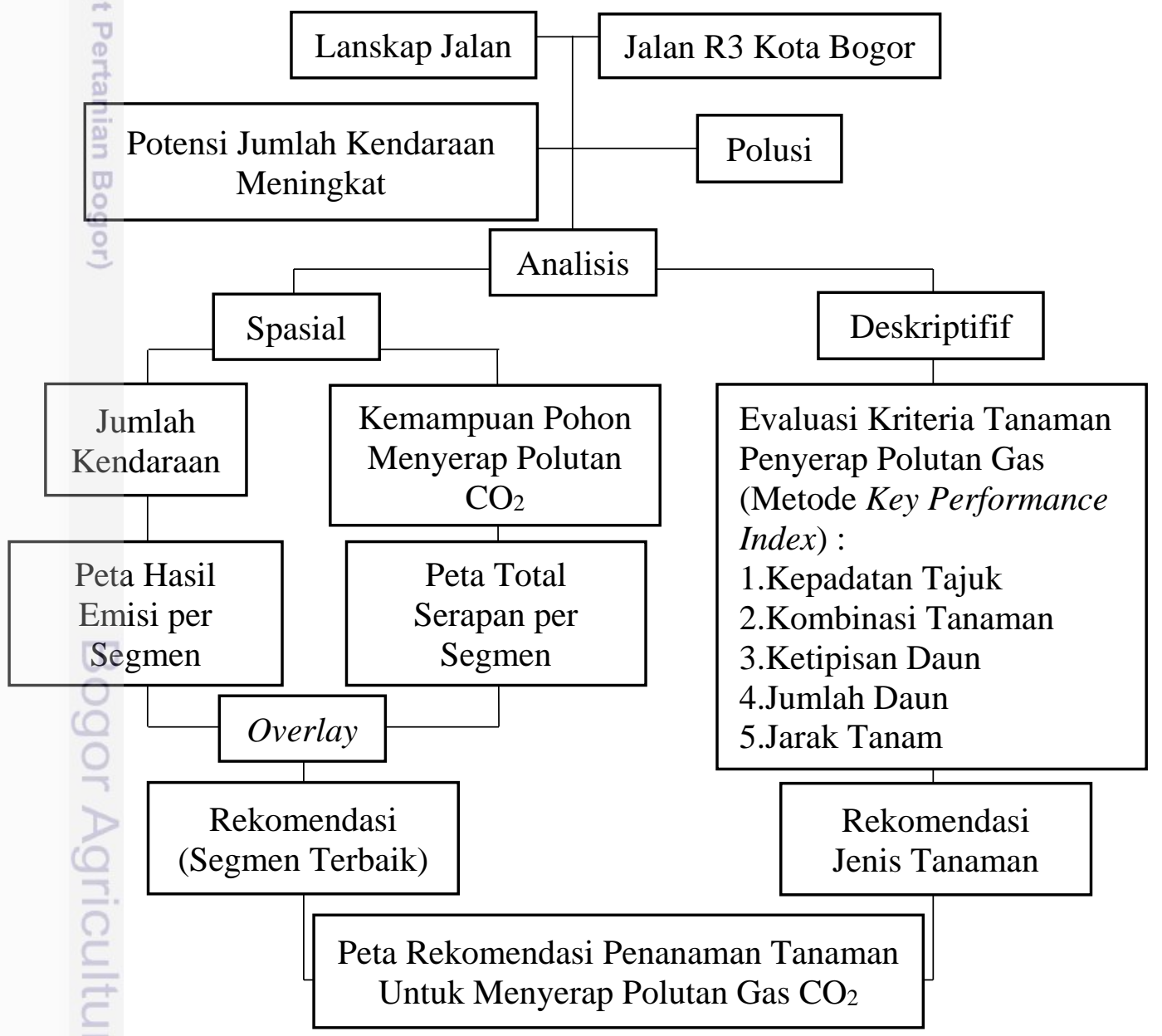

Gambar 1 Kerangka Pemikiran Studi Potensi Fungsi Ekologis pada Lanskap Jalan R3 Kota Bogor 


\section{TINJAUAN PUSTAKA}

\section{Evaluasi}

Evaluasi adalah kegiatan menilai, menaksir, dan mengkaji (Echols dan Shadily 1996). Menurut Eliza dalam Vitasari (2004), evaluasi adalah suatu tindakan yang digunakan atau dilakukan untuk menelaah atau menduga hal-hal yang sudah diputuskan untuk mengetahui kelemahan dan kelebihan keputusan tersebut untuk selanjutnya ditentukan langkah-langkah alternatif perbaikannya bagi kelemahan tersebut. Evaluasi perlu dilakukan untuk mengetahui apakah tujuan telah tercapai dan peningkatan yang perlu dilakukan.

Kegiatan evaluasi bertujuan menyeleksi dan menampilkan informasi yang diperlukan dalam mendukung pengambilan kesimpulan dan keputusan tentang suatu nilai serta nilainya (Anonim dalam Vitasari, 2004). Anonim dalam Vitasari 2004 juga menyatakan bahwa evaluasi dilakukan untuk menentukan keputusan apa akan melanjutkan suatu program yang dinilai sukses atau menghentikannya. Evaluasi dilakukan dengan menggunakan pembanding yaitu perbandingan hasil perencanaan dengan tujuan yang ditetapkan oleh desainer. Hasil evaluasi digunakan untuk membantu memutuskan apa suatu program akan dilanjutkan atau dihentikan dan bagaimana cara pengembangannya.

\section{Lanskap Jalan}

Menurut Undang-Undang Republik Indonesia Nomor 38 tahun 2004, jalan adalah suatu prasarana perhubungan darat yang meliputi segala bagian jalan, termasuk bangunan pelengkap dan perlengkapannya yang diperuntukkan bagi lalu lintas, yang berada pada permukaan tanah, di atas permukaan tanah, di bawah permukaan tanah, dan/atau air serta di atas permukaan air, kecuali jalan kereta api, jalan lori, dan jalan kabel. Harris dan Dines (1988) menjelaskan bahwa adanya jalan atau sirkulasi kendaraan di jalan raya mengakomodasikan tiga tujuan utama yaitu menyediakan akses untuk masuk ke suatu lahan dan bangunan, menghubungkan antar tata guna lahan yang ada, dan menyediakan jalur pergerakan untuk orang dan barang.

Berdasarkan peruntukannya, jalan dibedakan menjadi jalan umum dan jalan khusus (UU No. 38 tahun 2004). Jalan umum adalah jalan yang diperuntukkan bagi lalu lintas umum dan dikelompokkan menurut sistem, fungsi, status, dan kelas. Jalan khusus adalah jalan yang dibangun oleh instansi, badan usaha, perseorangan, atau kelompok masyarakat untuk kepentingan sendiri, diperuntukkan bukan bagi lalu lintas umum dalam rangka distribusi barang dan jasa yang diperlukan. Jalan khusus tidak diperuntukkan bagi lalu lintas umum. Termasuk ke dalamnya antara tain jalan inspeksi pengairan, jalan inspeksi saluran minyak atau gas, jalan perkebunan, jalan pertambangan, jalan kehutanan, jalan komplek bukan untuk umum dan jalan untuk keperluan pertahanan dan kemanan Negara.

Jalan umum dikelompokkan lebih lanjut menurut fungsi, status dan kelasnya. Jalan umum menurut statusnya dikelompokkan ke dalam jalan nasional, jalan provinsi, jalan kabupaten, jalan kota, dan jalan desa. Menurut fungsinya, jalan umum dikelompokkan menjadi jalan arteri, jalan kolektor, jalan lokal, dan jalan 


\section{lingkungan.}

1. Jalan arteri merupakan jalan umum yang berfungsi melayani angkutan utama dengan ciri perjalanan jarak jauh, kecepatan rata rata tinggi, dan jumlah jalan masuk dibatasi secara berdaya guna,

2. Jalan kolektor merupakan jalan umum yang berfungsi melayani angkutan pengumpul atau pembagi dengan ciri perjalanan jarak sedang, kecepatan ratarata sedang, dan jumlah jalan masuk dibatasi,

3. Jalan lokal merupakan jalan umum yang berfungsi melayani angkutan setempat dengan ciri perjalanan jarak dekat, kecepatan rata-rata rendah, dan jumlah jalan masuk tidak dibatasi,

4. Jalan lingkungan merupakan jalan umum yang berfungsi melayani angkutan lingkungan dengan ciri perjalanan jarak dekat, dan kecepatan rata-rata rendah.

Jalan memiliki beberapa bagian jalan. Bagian-bagian jalan tersebut meliputi ruang manfaat jalan, ruang milik jalan, dan ruang pengawasan jalan (UU RI No 38 tahun 2004; UU RI No 13 tahun 1980).

1. Daerah manfaat jalan adalah suatu daerah yang dimanfaatkan untuk konstruksi jalan terdiri dari badan jalan, saluran tepi jalan, dan ambang pengamannya,

2. Daerah milik jalan meliputi daerah manfaat jalan dan sejalur tanah tertentu, di luar daerah manfaat jalan. Daerah milik jalan dibatasi tanda batas daerah milik jalan,

3. Daerah pengawasan jalan merupakan sejalur tanah tertentu di luar daerah milik jalan yang ada di bawah pengawasan Pembina jalan. Adanya daerah pengawasan jalan dimaksudkan agar tidak mengganggu pandangan pengemudi dan konstruksi jalan, dalam hal tidak cukup luasnya daerah milik jalan.

Jalan selain dibedakan berdasarkan fungsi dan administrasi pemerintah, juga ada diklasifikasikan didasarkan pada faktor muatan sumbu atau dikenal dengan istilah jalan hirarki.

a. Jalan kelas I merupakan jalan arteri yang dapat dilewati kendaraan angkut berukuran lebar meksimal 2.500 milimeter $(2,5 \mathrm{~m})$, dan panjang masksimal adalah 1.800 milimeter $(1,8 \mathrm{~m})$. Sementara di Indonesia ini untuk muatan sumbu terberat yang diizinkan lebih dari 10 ton,

b. Jalan kelas II merupakan jalan arteri yang bias dilewati kendaraan bermotor dengan ukuran lebar maksimal adalah 2.500 milimeter $(2.5 \mathrm{~m})$, sementara untuk ukuran panjang maksimalnya adalah 18.000 milimeter $(18 \mathrm{~m})$. Untuk muatan sumbu terberat yang diizinkan adalah 10 ton, dimana jalan kelas ini biasanya merupakan jalan yang digunakan untuk angkutan peti kemas,

c. Jalan kelas III A merupakan jalan raya yang dapat dilalui angkatan berukuran lebar maksimal 2.500 milimeter $(2,5 \mathrm{~m})$, dan panjang maksimalnya adalah 18.000 milimeter $(18 \mathrm{~m})$. Sementara muatan sumbu terberat yang diizinkan adalah 8 ton,

d. Jalan kelas III B merupakan jalan kolektor yang dapat dilalui kendaraan bermotor termasuk muatan dengan ukurab lebar tidak melebihi 12.000 milimeter, dan muatan sumbuu terberat yang diizinkan 8 ton,

e. Jalan kelas III C merupakan jalan local dan jalan lingkungan yang bias dilewati kendaraan bermotor termasuk kendaraan angkut berukuran lebar maksimak 2.100 milimeter $(2,1 \mathrm{~m})$ dan panjangnya tidak boleh lebih dari 9.000 milimeter (9m). Sementara muatan sumbu maksimalnya adalah 8 ton.

Lanskap jalan mempunyai ciri khas karena harus disesuaikan dengan persyaratan 
geometrik jalan dan diperuntukkan terutama bagi pengguna jalan serta diusahakan untuk menciptakan lingkungan yang indah, nyaman, dan memenuhi fungsi keamanan (Direktorat Jenderal Bina Marga, 1996). Agar tercipta lingkungan jalan yang nyaman dan teduh, diperlukan tanaman peneduh pada jalan (Dahlan, 2004). Adanya tanaman pada jalan menurut Carpenter et al (1975) dapat memberi karakter dan melembutkan struktur jalan yang keras dan kaku.

Direktorat Jenderal Bina Marga (1996) menjelaskan bahwa persyaratan utama dalam memilih jenis tanaman lanskap jalan yaitu perakaran tidak merusak konstruksi jalan, mudah dalam perawatan, batang/percabangan tidak mudah patah, daun tidak mudah rontok/gugur. Selain itu, pemilihan tanaman jalan perlu mempertimbangkan faktor keamanan pemakai jalan.

\section{Jalur Hijau}

Jalur hijau jalan merupakan salah satu bentuk penyediaan ruang terbuka hijau pada kota. Berdasarkan Undang-Undang Republik Indonesia nomor 26 tahun 2007, RTH atau ruang terbuka hijau sendiri didefinisikan sebagai area memanjang, jalur, dan atau mengelompok, yang pengunaannya lebih bersifat terbuka, dan merupakan tempat tumbuh tanaman, baik yang tumbuh secara alami maupun sengaja ditanaman. Proporsi luas ruang terbuka hijau pada kota paling sedikit $30 \%$ luas wilayah kota. Proporsi ruang terbuka hijau 30\% tersebut merupakan ukuran minimal untuk menjamin keseimbangan ekosistem kota, meingkatkan ketersediaan üdara bersih bagi masyarakat dan juga meningkatkan nilai estetika kota.

Menurut Peraturan Menteri Pekerjaan Umum Nomor 5 tahun 2008, jalur hijau adalah jalur penempatan tanaman serta elemen lanskap lainnya yang terletak di dalam ruang milik jalan (RUMIJA) maupun di dalam ruang pengawasan (RUWASJA). Sering disebut jalur hijau karena dominasi elemen lanskapnya adalah tanaman yang pada umumnya berwarna hijau. Contoh tata letak tanaman jalur hijau jalan dapat dilihat di Gambar 2.

Fungsi utama ruang terbuka hijau yaitu fungsi ekologis menjamin system sirkulasi udara kota, pengatur, iklim mikro, peneduh, produsen oksigen, penyerapan air hujan, penyerapan polutan, habitat satwa, dan penahan angina. RTH selain memiliki fungsi ekologis juga memiliki fungsi social budaya dan fungsi ekonomi. RTH berfungsi untuk memperindah lingkungan kota dan menciptakan keseimbangan dan keserasian susasana pada area yanf terbangun maupun tidak terbangun. Manfaat RTH antara lain terbentuknya keindahan, kenyamanan, pembersih udara, menjamin ketersediaan air tanah, dan konservasi hayati.

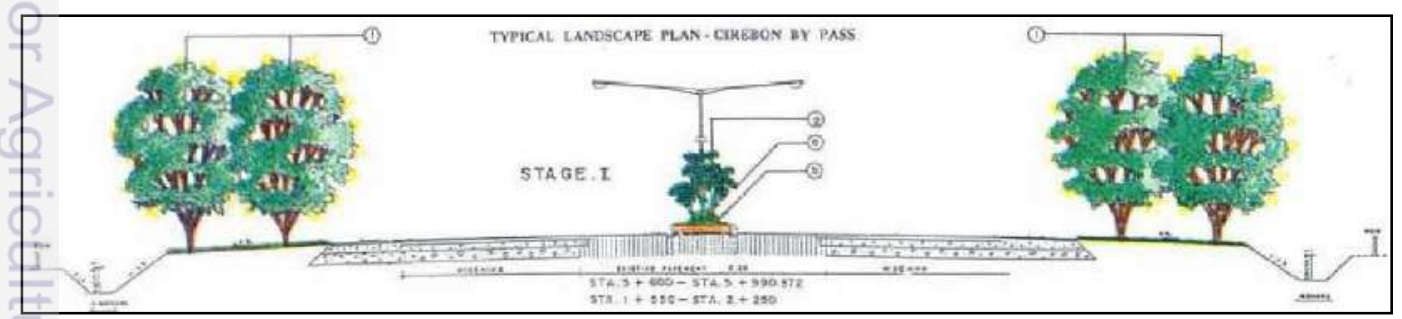

Gambar 2 Tata Letak Tanaman pada Jalur Hijau (DPU Dirjen Bina Marga, 1996) 


\section{Pencemaran Udara}

Simonds (1978) menjelaskan bahwa polusi terjadi ketika suatu aktivitas atau proses menghasilkan produk samping yang mengganggu dan mengakibatkan terganggunya susunan atau system alami atau buatan. Udara merupakan komponen penting dalam kehidupan manusia. Tanpa udara, tidak ditemukan adanya kehidupan. Manusia bernapas dengan udara. Tercemarnya udara akan menyulitkan pernapasan sehingga kualitas kehidupan menurun (Frick dan Suskiyanto, 2007). Komposisi udara mencakup $78 \%$ nitrogen, $21 \%$ oksigen dan sisanya terdiri dari karbon dioksida dan unsur-unsur lain.

Pencemaran udara adalah adanya bahan-bahan atau zat-zat asing di dalam udara yang menyebabkan perubahan susunan (komposisi) udara dari dalam keadaan normalnya (Wardhana, 2001). Kehadiran bahan atau zat asing ini pada jumlah tertentu dan waktu yang cukup lama akan dapat mengganggu kehidupan manusia, hewan, dan binatang.

Grey dan Deneke (1978) menyebutkan bahwa polutan udara dapat berbentuk gas maupun partikel. Komponen pencemar udara yang banyak berpengaruh pada pencemaran udara yaitu karbon monoksida $(\mathrm{CO})$, nitrogen oksida (NOx), belerang oksida (SOx), hidrokarbon (HC), partikel (particulate). Kelima kelompok pencemar udara primer ini memiliki dampak negatif bagi kesehatan manusia.

Tabel 1 Toksisitas Relatif Polutan Udara

\begin{tabular}{cccc}
\hline \multirow{2}{*}{ Polutan } & \multicolumn{2}{c}{ Level toleransi } & \multirow{2}{*}{ Toksisitas relatif } \\
\cline { 2 - 3 } & $\mathrm{Ppm}$ & $\mu \mathrm{g} / \mathrm{m}^{3}$ & 1,00 \\
ICO & 32,0 & 40,000 & 2,07 \\
IHC & & 19,300 & 28,00 \\
SOx & 0,50 & 1430 & 77,80 \\
NOx & 0,25 & 514 & 106,70 \\
Partikel & & 375 & \\
\hline
\end{tabular}

Sumber: Fardiaz, 1992

Jenis polutan yang paling berbahaya bagi kesehatan manusia, berdasarkan tingkat toksisitasnya, yaitu partikel, kemudian diikuti nitrogen oksida (NOx), belerang oksida (SOx), hidrokarbon (HC), dan yang terakhir karbon monoksida (Fardiaz, 1992). Karbon monoksida merupakan kelompok polutan yang paling rendah toksisitasnya, dapat dilihat di Tabel 1.

Simond (1978) menyebutkan bahwa sebagian besar polusi disebabkan oleh manusia, terutama dari pembakaran bahan bakar fosil di rumah, pabrik, dan kendaraan bermotor. Rute transportasi dan jalan raya terutama adalah sumber utama dari polusi udara dan suara. Sumber-sumber polusi lain yaitu pembakaran, proses industri, pembuangan limbah, dan lain-lain. Wardhana (2001) menjelaskan sebagian besar zat pencemar udara, yaitu sebanyak $75 \%$, berasal dari gas buangan hasil pembakaran bahan bakar fosil. Udara daerah perkotaan yang memiliki banyak kegiatan industri dan lalu lintas padat cenderung tidak bersih. Hajderi dan Bozo (2014) menjelaskan bahwa pencemaran udara akibat dari kendaraan bermotor dapat meningkatkan kemungkinan terjadinya kematian, pemendekan umur, penyakit pernapasan, tumor (kanker) dan penyakit hormon.

Untuk mencegah terjadinya pencemaran udara serta terjaganya mutu udara, 
maka pemerintah menentapkan Baku Mutu Udara Ambien Nasional yang terlampir dalam Peraturan Pemerintah Nomor 41 Tahun 1999. Nilai Baku Mutu Ambien tersebut dapat dilihat di Tabel 2.

Tabel 2 Baku Mutu Udara Ambien

\begin{tabular}{|c|c|c|c|c|}
\hline Parameter & $\begin{array}{l}\text { Waktu } \\
\text { Pengukuran }\end{array}$ & Baku Mutu & $\begin{array}{l}\text { Metode } \\
\text { Analisis }\end{array}$ & Peralatan \\
\hline $\begin{array}{l}\mathrm{SO}_{2} \\
\text { (Sulfur Dioksida) }\end{array}$ & $\begin{array}{l}\text { 1 Jam } \\
24 \text { Jam } \\
1 \text { Tahun }\end{array}$ & $\begin{array}{l}900 \mu \mathrm{g} / \mathrm{Nm}^{3} \\
365 \mu \mathrm{g} / \mathrm{Nm}^{3} \\
60 \mu \mathrm{g} / \mathrm{Nm}^{3}\end{array}$ & Pararosanilin & Spektrofotometer \\
\hline $\begin{array}{l}\mathrm{CO} \\
\text { (Karbon Monoksida) }\end{array}$ & $\begin{array}{l}1 \text { Jam } \\
24 \text { Jam } \\
1 \text { Tahun }\end{array}$ & $\begin{array}{l}30.000 \mu \mathrm{g} / \mathrm{Nm}^{3} \\
10.000 \mu \mathrm{g} / \mathrm{Nm}^{3}\end{array}$ & NDIR & NDIR Analyzer \\
\hline $\begin{array}{l}\mathrm{NO}_{2} \\
\text { (Nitrogen Dioksida) }\end{array}$ & $\begin{array}{l}1 \text { Jam } \\
24 \text { Jam } \\
1 \text { Tahun }\end{array}$ & $\begin{array}{l}400 \mu \mathrm{g} / \mathrm{Nm}^{3} \\
150 \mu \mathrm{g} / \mathrm{Nm}^{3} \\
100 \mu \mathrm{g} / \mathrm{Nm}^{3}\end{array}$ & Saltzman & Spektrofotometer \\
\hline $\begin{array}{l}\mathrm{O}_{3} \\
\text { (Oksida) }\end{array}$ & $\begin{array}{l}1 \text { Jam } \\
1 \text { Tahun }\end{array}$ & $\begin{array}{l}235 \mu \mathrm{g} / \mathrm{Nm}^{3} \\
50 \mu \mathrm{g} / \mathrm{Nm}^{3}\end{array}$ & $\begin{array}{l}\text { Chemi- } \\
\text { luminescent }\end{array}$ & Gas Chromatografi \\
\hline $\begin{array}{l}\text { HC } \\
\text { (Hidro Karbon) }\end{array}$ & 3 jam & $160 \mu \mathrm{g} / \mathrm{Nm}^{3}$ & $\begin{array}{l}\text { Flamed } \\
\text { Ionization }\end{array}$ & Hi-Vol \\
\hline $\begin{array}{l}\text { PM10 } \\
(\text { Partikel < } 10 \text { mm) }\end{array}$ & 24 jam & $\begin{array}{l}65 \mu \mathrm{g} / \mathrm{Nm}^{3} \\
15 \mu \mathrm{g} / \mathrm{Nm}^{3}\end{array}$ & Gravimetric & Hi-Vol \\
\hline $\begin{array}{l}\text { PM 2,5* } \\
(\text { Partikel < 2,5 mm) }\end{array}$ & $\begin{array}{l}24 \text { jam } \\
1 \text { tahun }\end{array}$ & $\begin{array}{l}230 \mu \mathrm{g} / \mathrm{Nm}^{3} \\
90 \mu \mathrm{g} / \mathrm{Nm}^{3}\end{array}$ & Gravimetric & Hi-vol \\
\hline $\mathrm{Pb}($ Timah Hitam) & $\begin{array}{l}24 \text { jam } \\
1 \text { tahun }\end{array}$ & $\begin{array}{l}3 \mu \mathrm{g} / \mathrm{Nm}^{3} \\
0,5 \mu \mathrm{g} / \mathrm{Nm}^{\mathrm{c}}\end{array}$ & $\begin{array}{l}\text { Gravimetric } \\
\text { Ekstraktif } \\
\text { Pengabuan }\end{array}$ & $\begin{array}{l}\text { Hi-vol } \\
\text { AAS }\end{array}$ \\
\hline Dustfall (Debu Jatuh) & 30 hari & $\begin{array}{l}10 \text { ton } / \mathrm{km}^{2} / \mathrm{bln} \\
\text { (pemukiman) } \\
10 \text { ton } / \mathrm{km}^{2} / \mathrm{bln}\end{array}$ & Gravimetric & Cannister \\
\hline Total Flourides (as F) & $\begin{array}{l}24 \text { jam } \\
90 \text { hari }\end{array}$ & $\begin{array}{l}3 \mu \mathrm{g} / \mathrm{Nm}^{3} \\
0.5 \mu \mathrm{g} / \mathrm{Nm}^{3} \\
40 \mu \mathrm{g} / 100 \mathrm{~cm}^{2}\end{array}$ & $\begin{array}{l}\text { Specific Ion } \\
\text { Electrode }\end{array}$ & $\begin{array}{l}\text { Impigner atau } \\
\text { Continous analyzer }\end{array}$ \\
\hline Flour Indeks & 30 hari & $\begin{array}{l}\text { dari Kertas } \\
\text { Limed Filter }\end{array}$ & Colorimetric & Limed Filter Paper \\
\hline $\begin{array}{l}\text { Khlorine \& Khlorine } \\
\text { Dioksida }\end{array}$ & 24 jam & $150 \mu \mathrm{g} / \mathrm{Nm}^{3}$ & $\begin{array}{l}\text { Specific ion } \\
\text { electrode }\end{array}$ & $\begin{array}{l}\text { Impigner atau } \\
\text { Continous Analyzer }\end{array}$ \\
\hline Sulphat Indeks & 30 hari & $\begin{array}{l}1 \mathrm{mg} \mathrm{SO} / \mathrm{cm}^{3} \\
\text { dari Lead } \\
\text { Peroksida }\end{array}$ & Colorimetric & $\begin{array}{l}\text { Lead Peroxide } \\
\text { Candle }\end{array}$ \\
\hline
\end{tabular}

Sumber: PPRI No. 41 Tahun 1999

Catatan: *PM 2,5 mulai berlaku tahun 2002

\section{Polutan CO2}

Gas karbon dioksida (CO2) berasal dari hasil pembakaran hutan, industri, pesawat terbang, pesawat luar angkasa, kapal dan mesin-mesin seperti motor, mobil, serta kereta api. Hasil pembakaran tersebut akan meningkatkan kadar CO2, sehingga udara tercemar. Apabila kadar $\mathrm{CO} 2$ di udara terus meningkat dan melebihi batas tolerasi yaitu melebihi $0,0035 \%$ serta tidak segera diubah oleh vegetasi menjadi oksigen, maka dapat menyebabkan terbentuknya gas rumah kaca yang efeknya akan meningkatkan pemanasan global suhu bumi (global warming). Hal tersebut terjadi karena sebagian sinar matahari yang masuk ke bumi dipantulkan ke 
luar angkasa. Karena tertahan oleh adanya rumah kaca, maka sinar tersebut tetap berada di permukaan bumi dan akan meningkatkan suhu bumi (pemanasan global).

Pemanasan global ini dapat mengakibatkan bahaya kekeringan yang hebat yang mengganggu kehidupan manusia dan mencairnya lapisan es di daerah kutub. Gas karbon dioksida ini berasal dari asap pabrik, pembakaran sampah, kebakaran hutan, dan asap kendaraan bermotor. Selain itu, efek dari gas rumah kaca juga dipicu oleh hasil pembakaran fosil (batu bara dan minyak bumi) yang berupa hasil buangan bentuk $\mathrm{CO} 2$ dan sulfur belerang.

Jumlah emisi CO2 pada suatu Kawasan dapat dihitung secara matematika sederhana. Menurut Adiastari (2010) data jumlah kendaraan serta luas tutupan vegetasi pada suatu kawasan dapat di konversi dan dijadikan data parameter jumlah total emisi tersisa pada suatu jalan atau kawasan.

\section{Fungsi Ekologis Tanaman Dalam Lanskap}

Ekologi berasal dari bahasa Yunani yaiut oikos yang berarti rumah atau tempat untuk tinggal. Secara umum, ekologi didefinisikan sebagai studi tentang hubungan dari organisme atau kelompok dengan lingkungannya atau ilmu tentang hubungan timbal balik antara makhluk hidup dan lingkungannya (Odum, 1959). Tumbuhan turut berperan dalam menjaga keseimbangan ekologis pada lingkungan. Ekologi merupakan ilmu yang dapat meningkatkan berbagai pengetahuan karena melibtakan pemahaman hubungan antara semua organisme kehidupan termasuk manusia dan lingkungannya (Steiner, 2016)

Jrwan (2008) menjelaskan bahwa vegetasi dalam ekosistem berperan sebagai produsen utama yang mengubah energy surya menjadi energy potensial. Energy yang dihasilkan oleh vegetasi merupakan sumber hara mineral dan perubah terbesar lingkungan yang dapat meningkatkan kualitas lingkungan. Benson dan Roe (2000) menyebutkan bahwa vegetasi penting dalam berfungsi secara ekologis dan merupakan salah satu faktor penting dalam menciptakan eberlanjutan lingkungan. Beberapa fungsi ekologis tanaman dan vegetasi antara lain control polusi, meningkatkan kualitas udara, ameliorasi iklim, mereduksi bising, menyimpan karbon dan sebagai keanekaragaman hayati.

\section{Fungsi Tanaman Sebagai Penyerap Polutan Gas}

Tanaman dapat mengurangi polutan udara melalui proses oksigenasi, yaitu proses pelepasan oksigen ke atmosfer, dan dilusi, yaitu pencampuran udara tercemar dengan udara bersih. Ketika udara yang tercemar mengalir di dalam dan sekitar tanaman dan melewati udara bersih dan beroksigen, terjadi pencampuran antara udara yang tercemar dengan udara bersih sehingga konsentrasi zat pencemar udara berkurang, dapat dilihat Gambar 3 (Carpenter et al., 1975). Selain vegetasi, pergerakan angin juga dapat mempengaruhi penyebaran polusi udara. Karena itu, untuk mengurangi polusi udara, penanaman vegetasi dapat dilakukan tegak lurus dengan arah angin (Grey dan Deneke, 1978). Selain itu, penanaman juga ditempatkan di sekitar sumber polusi dan juga dikombinasikan dengan barrier yang padat. Bennet dan Hill (1973) menyebutkan bahwa gas pencemaran udara seperti 
$\mathrm{HF}, \mathrm{SO}_{2}$, dan $\mathrm{NO}_{2}$ dapat direduksi dengan adanya pohon dengan kanopi yang lebat serta oleh vegetasi yang berada di permukaan tanah.

Tanaman menyerap karbondioksida dan melepaskan oksigen. Tanaman memiliki efek yang kecil pada tingkat karbon dioksida dan oksigen kota. Walaupun demikian, sedikit penurunan pada tingkat suplai oksigen dunia akan menghasilkan peningkatan yang cukup besar pada persentase karbon dioksida (Harris et al 1999). Schmid dalam Harris et al (1999) menemukan bahwa konsentrasi ozon berkurang dengan cepat pada siang hari dimana tanaman bertranspirasi dengan cepat dibandingkan pada malam hari. Transpirasi mendinginkan udara yang akan memperlambat pembentukan ozon. Nitrogen dioksida dihilangkan secara parsial oleh presipitasi.

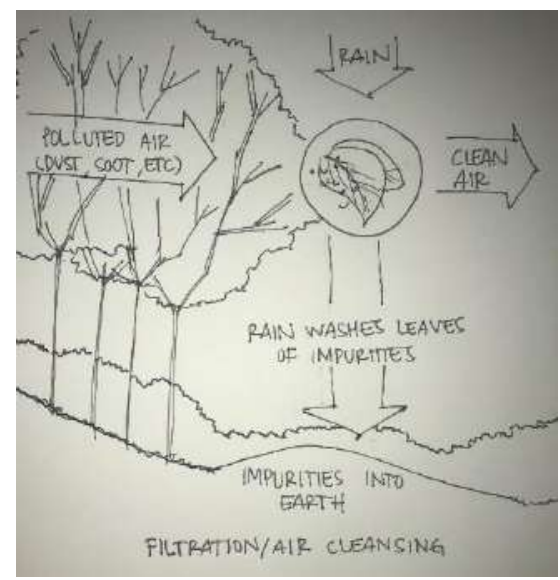

Gambar 3 Tanaman Menjernihkan Udara (Carpenter et al., 1975)

Polutan diserap oleh jaringan tanaman yang aktif, terutama di daun dan dijerap pada permukaan tanaman (Harris et al 1999). Tanaman dapat menjadi penyaring yang efektif dan dapat digunakan untuk pada area-area strategis untuk membersihkan udara. Tanaman dapat menyerap dan menjerap gas dan polutan padat sampai pada batas tertentu yang dapat ditoleransi oleh tanaman. Penggunaan tanaman yang peka terhadap polusi udara pada lingkungan yang tercemar berat dapat menyebabkan tumbuhan menderita bahkan mati. Dengan diketahuinya jenis tanaman yang tahan terhadap pencemar udara, tanaman akan dapat tumbuh dengan baik walaupun terkena paparan pencemar udara sedang sampai tinggi (Dahlan, 2004). Karena itu, pemilihan tanaman untuk daerah dengan tingkat pencemaran tinggi, misalnya jalan yang tercemar, perlu dilakukan dengan cermat.

Fakuara (1986) dalam Setiawati (2000) menjelaskan bahwa jenis tanaman yang dapat menyerap gas antara lain tanaman yang mempunyai banyak stomata, tahan terhadap gas tertentu dan tingkat pertumbuhan tanaman cepat. Kemampuan daun tanaman dalam menyerap gas beracun pencemar udara dipengaruhi beberapa faktor antara lain daya kelarutan polutan di dalam air/cairan sel, kelembaban lingkungan di sekitar daun, intensitas cahaya matahari, kedudukan daun, keadaaan saat penyerapan (gelap/terang) (Smith, 1981 dalam Dahlan, 2004). Selain vegetasi, pergerakan angin juga dapat mempengaruhi penyebaran polusi udara. Karena itu, untuk mengurangi polusi udara, penanaman vegetasi dapat dilakukan tegak lurus dengan arah angin (Grey dan Deneke, 1978). Selain itu, penanaman juga ditempatkan di sekitar sumber polusi. Penanaman yang terbuka sebaiknya juga dikombinasikan dengan barrier yang padat. 


\section{METODOLOGI}

\section{Lokasi dan Waktu Penelitian}

Lokasi penelitian akan dilakukan di Jalan R3, Kota Bogor, Jawa Barat (Gambar 4). Jangka waktu penelitian mulai dari Maret 2016 sampai Desember 2017.

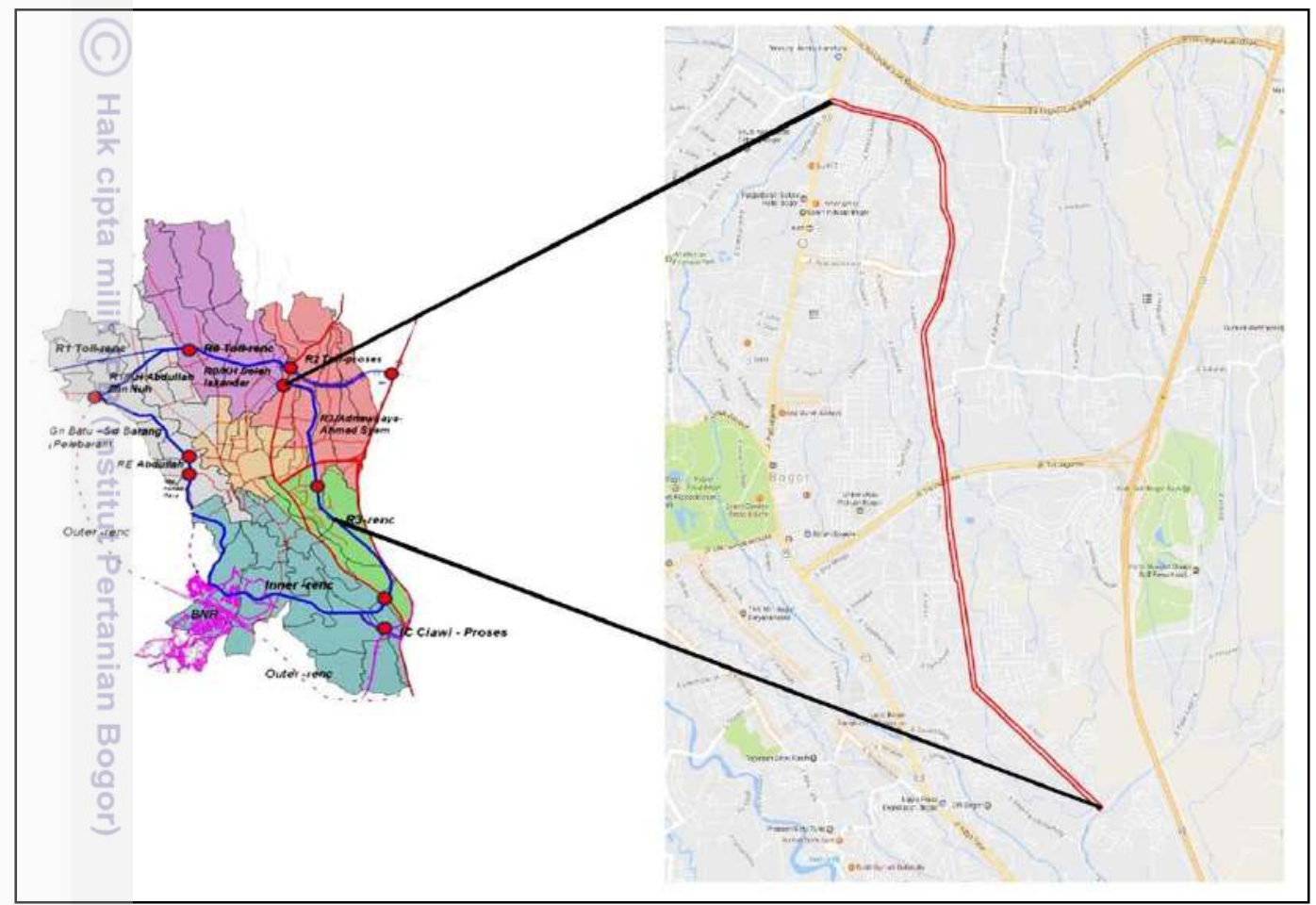

Gambar 4 Peta Kota Bogor \& Peta Jalan R3 Kota Bogor

\section{Alat dan Bahan}

Bahan-bahan yang digunakan dalam penelitian ini berupa data primer dan sekuder, yaitu:

1. Peta jalan R3 Kota Bogor,

2. data fisik dan biofisik,

3. data tataguna lahan,

4. data titik pohon,

5. data amdal,

6. studi pustaka.

Alat-alat yang digunakan untuk penelitian ini yaitu:

1. Alat tulis/catatan,

2. kamera digital/HP,

3. komputer,

4. software-software yang digunakan, anatara lain AutoCad 2017, Arcgis 9.3, Microsoft Power Point 2017, Microsoft Word 2017, Microsoft Excel 2017, dan Adobe Photoshop 2017. 


\section{Metode Penelitisn}

Metode yang digunakan pada penelitian ini adalah metode deskripsi dan analisis spasial. Metode deskripsi digunakan untuk menganalisis dan menjabarkan data yang ada serta fungsi ekologis yang akan diteliti, sedangkan analisis spasial digunakan untuk mengspasialkan hasil penelitian. Kegiatan penelitian ini dibagi menjadi berbagai tahapan yaitu, tahap persiapan, tahap inventarisasi, tahap analisis, tahap evaluasi, dan tahap sintesis (rekomendasi).

\section{Tahap Persiapan}

Pada tahap persiapan dilakukan berbagai hal untuk mempersiapkan pelaksanaan peneletian. Kegiatan-kegiatan yang dilakukan meliputi perumusan üsulan penelitian, pemilihan lokasi, dan studi pustaka dari berbagai litelatur. Studi pustaka yang dilakukan untuk mendapatkan standar dan kriteria lanskap jalan sebagai pembanding untuk peniliaian fungsi ekologis. Standar berupa karakteristik vegetasi yang dapat memenuhi fungsi ekologis sebagai pereduksi polutan. Jenis data yang dibutuhkan untuk penelitian ini dijabarkan pada Tabel 3.

Tabel 3 Jenis, Parameter, Bentuk dan Sumber Data

\begin{tabular}{|c|c|c|c|}
\hline Jenis Data & Parameter & Bentuk & Sumber \\
\hline Letak geografis & Batas, luas wilayah, akses & Data sekunder & $\begin{array}{l}\text { Survei lapang, } \\
\text { litelatur }\end{array}$ \\
\hline Tata guna lahan & Pola pengunaan lahan & $\begin{array}{l}\text { Data primer } \\
\text { dan sekunder }\end{array}$ & $\begin{array}{l}\text { Survei Lapang, BPS } \\
\text { Kota Bogor }\end{array}$ \\
\hline Iklim & $\begin{array}{l}\text { Suhu, curah hujan, } \\
\text { kelembaban }\end{array}$ & Data sekunder & BMKG \\
\hline Tanah & Jenis Tanah & Data sekunder & BPS Kota Bogor \\
\hline Vegetasi & $\begin{array}{l}\text { Jenis pohon, jumlah, luas, } \\
\text { letak, kondisi lapang }\end{array}$ & $\begin{array}{l}\text { Data primer } \\
\text { dan sekunder }\end{array}$ & Survei Lapang, \\
\hline Kualitas udara & $\begin{array}{l}\text { Jenis dan jumlah zat } \\
\text { pencemar }\end{array}$ & Data sekunder & DLH Kota Bogor \\
\hline $\begin{array}{l}\text { Standar fungsi } \\
\text { ekologis lanskap } \\
\text { jalan }\end{array}$ & $\begin{array}{l}\text { Karakteristik tanaman } \\
\text { untuk menyerap polusi }\end{array}$ & Data sekunder & Litelatur \\
\hline Jalan & Lokasi, dimensi, tata hijau & $\begin{array}{l}\text { Data primer } \\
\text { dan sekunder }\end{array}$ & $\begin{array}{l}\text { Survei Lapang, } \\
\text { Data PU }\end{array}$ \\
\hline Volume & Jumlah Kendraan & Data primer & Survei Lapang \\
\hline
\end{tabular}

\section{Tahap Inventarisasi}

Tahap inventarisasi dilakukan untuk memperoleh gambaran lengkap kondisi tapak serta pengumpulan data-data yang digunakan di penilitian. Data-data penelitian di dapatkan dari dinas terkait dan juga di dapat dengan cara survei langsung ke tapak penelitian. Data-data terebut juga dilihat dari referensinya sehingga data tersebut dapat di pertanggung jawabkan. 


\section{Tahap Analisis Spasial}

Analsis dilakukan secara spasial dan deskriptif dari data-data yang didapat dari inventarisasi. Analisis secara spasial dilakukan untuk mengetahui kondisi lapang serta sebaran pohon yang kemudian dibandingkan dengan data litelatur. Data spasial yang dicari berupa jumlah kendaraan yang di dapat dengan survei langsung ke lapang dan data kemampuan serapan polusi pada vegetasi yang tersebar di sepanjang jalan R3. Pada penelitian ini jenis polusi co2 lebih difokuskan, hal itu karena $\mathrm{CO} 2$ merupakan hasil emisi tertinggi yang dihasilkan kendraan bermotor.

\section{Sebaran dan Jumlah Pohon}

Perhitungan sebaran dan jumlah pohon pada Jalan R3 Kota Bogor dilakukan dengan cara survei langsung ke lapang. Untuk memudahkan perhitungan jumlah dan sebaran, maka dilakukan pendataan di setiap median dan tepi jalan yang terdapầt di lokasi penelitian. Kemudian dari data tersebut diolah dengan menggunkan aplikasi autocad untuk dijadikan peta sebaran sebaran pohon pada Jalan R3 Kota Bogor. Peta tersebut kemudian dibagi menjadi 9 segmen untuk memperjelas sebaran dan jumlah pohon.

\section{Jumlah Kendaraan}

Perhitungan jumlah dan jenis kendaraan yang melintas di Jalan R3 Kota Bogor dilakukan di 9 segmen yang sudah ditentukan pada pembuatan peta sebaran pohon. Perhitungan dilakukan selama satu jam dan diulang sebanyak 4 kali agar mendapat data yang akurat. Waktu pendataan dilakukan pada jam 08:00, jam 12:00, jam 16:00 dan jam 20:00. Perhitungan jumlah kendaraan dilakukan dengan cara manual atau dengan alat penghitung mekanik.

\section{Daya Serap CO2}

Menurut Adiastari (2010), untuk menghitung kemampuan serapan jalur hijau adalah dengan cara mengkalikan luas tutupan vegetasi jalur hijau dengan laju serapan CO2 yang telah dikemukakan dalam Tinambunan (2006) yaitu 129,92 $\mathrm{kg} / \mathrm{ha} / \mathrm{jam}$ atau setara dengan 569,07 ton/ha/tahun

\section{Daya Serap CO2 = Luas penutupan vegetasi $x$ Laju serapan CO2}

Volume kendaraan dari tiap segmen yang diamati adalah volume kendaraan yang paling tinggi pada waktu pengamatan yang telah dilakukan, agar volume kendaraan yang diperoleh merupakan volume kendaraan maksimum sehingga emisi yang dihasilkan merupakan beban emisi maksimum. Perhitungan emisi akan dihitung dengan rumus berikut.

Keterangan :

$Q=\operatorname{Ni} \times$ Fei $\times$ Ki $\times L$

$\mathrm{Q}=$ Jumlah emisi (gr/jam)

$\mathrm{Ni}=$ Jumlah kendaraan bermotor tipe-i (kendaraan/jam)

Fei $=$ Faktor emisi kendaraan bermotor tipe-i (gr/liter)

$\mathrm{Ki}=$ Konsumsi bahan bakar kendaraan bermotor tipe-I (liter/100km)

$\mathrm{L}=$ Panjang Jalan $(\mathrm{km})$

Nilai faktor emisi dengan tipe bahan bakar dan jenis kendaraan dapat dilihat pada Tabel 4. Sedangkan untuk konsumsi bahan bakar yang telah disesuaikan dengan jenis kendarannya dapat dilihat pada Tabel 5. 
Tabel 4 Faktor Emisi Kendaraan Bermotor Berdasarkan Tipe Bahan Bakar

\begin{tabular}{lcccc}
\hline \multirow{2}{*}{$\begin{array}{c}\text { Tipe kendaraan/bahan } \\
\text { bakar }\end{array}$} & \multicolumn{4}{c}{ Faktor emisi (gr/liter) } \\
\cline { 2 - 5 } & $\mathrm{CH} 4$ & $\mathrm{CO}$ & $\mathrm{N} 2 \mathrm{O}$ & $\mathrm{CO} 2$ \\
\hline Bensin & & & & \\
Kendaraan/Penumpang & 0.71 & 462.63 & 0.04 & 2597.86 \\
Kendaraan niaga kecil & 0.71 & 295.37 & 0.04 & 2597.86 \\
Kendaraan niaga besar & 0.71 & 281.14 & 0.04 & 2597.86 \\
Sepeda motor & 3.56 & 427.05 & 0.04 & 2597.86 \\
\hline Diesel & & & & \\
Kendaraan/Penumpang & 0.08 & 11.86 & 0.16 & 2924.90 \\
Kendaraan niaga kecil & 0.04 & 15.81 & 0.16 & 2924.90 \\
Kendaraan niaga besar & 0.24 & 35.57 & 0.12 & 2924.90 \\
Lokomotif & 0.24 & 24.11 & 0.08 & 2924.90 \\
\hline
\end{tabular}

Sumber : IPCC dalam Jinca (2009)

Tabel 5 Konsumsi Energi Spesifik Kendaraan Bermotor

\begin{tabular}{lc} 
Jenis kendaraan & $\begin{array}{c}\text { Konsumsi energi spesifik kendaraan bermotor } \\
(\text { liter/100 km) }\end{array}$ \\
Mobil penumpang & 11.79 \\
- Bensin & 11.36 \\
- Diesel/solar & \\
- Bensin & 23.15 \\
- Diesel/solar & 16.89 \\
Bus sedang & 13.04 \\
Bus kecil & \\
- Bensin & 11.35 \\
- Diesel/solar & 11.35 \\
Bemo/Bajaj & 10.99 \\
Taksi & \\
- Bensin & 10.88 \\
- Diesel/solar & 6.25 \\
Truk besar & 15.82 \\
Truk sedang & 15.15 \\
Truk kecil & \\
- Bensin & 8.11 \\
- Diesel/solar & 10.64 \\
Sepeda motor & 2.66 \\
\hline
\end{tabular}

Sumber : BPPT dalam Jinca (2009)

Emisi karbon total merupakan penjumlahan dari nilai emisi karbon tiap jenis kendaraan di sepanjang Jalan R3 Kota Bogor. Dengan melakukan pendekatan matematis, secara sederhana debit emisi dapat direduksi oleh RTH berupa penutupan tajuk pohon di sepanjang jalan R3 Kota Bogor. 
Dari hasil analisis spasial tersebut dapat dihasilkan peta daya serap $\mathrm{CO} 2$ dan peta hasil emisi $\mathrm{CO} 2$, yang kemudian dua peta tersebut di overlay sehingga mendapatkan titik segmen terbaik pada jalan R3 Kota Bogor. Segmen terbaik tersebut akan dijadikan rekomendasi jalur hijau jalan.

\section{Tahap Analisis Deskriptif}

Selain analisis spasial juga dilakukan analisis deskriptif. Analisis tersebut dilakukan untuk membandingkan kondisi lapang dengan standar untuk mengetahui kelebihan dan kekurangan lanskap jalan. Jenis vegetasi dianalisis untuk mengetahui toleransi tanaman terhadap polusi udara. Analisis dilakukan dengan cara mengevaluasi jenis vegetasi yang ada pada Jalan R3 kota bogor dengan kriteria vegetasi sebagai penyerap polutan gas

Evaluasi dilakukan dengan penilaian fungsi ekologis tanaman sebagai penyerap polutan gas. Fungsi menyerap polutan gas dibedakan berdasarkan mekanisme tanaman dalam mengruangi zar pencemar tersebut. Penilaian dilakukan terhadap kondisi lapang dengan perbandingan standar idealnya yang didapat dari litelatur. Penilaian dilakukan dengan cara membandingkan ciri fisik serta kondisi lapang vegetasi dengan kriteria vegetasi sebagai penyerap polutan gas yang didapat dari litelatur, dapat dilihat di Tabel 6. Teknik penilaian fungsi tanaman sebagai penyerap polutan menggunakan rumus Key Perfomance Index (KPI) untuk memberi nilai sesuai dengan kriteria yang ada (Hidayat 2008).

Tabel 6 Kriteria Penilaian Fungsi Ekologis

\begin{tabular}{ll}
\hline Aspek Fungsi Pohon & Kriteria penilaian \\
\hline & 1. Kepadatan tajuk \\
& 2. Kombinasi tanaman \\
Penyerap polutan gas & 3. Ketipisan daun \\
& 4. Jumlah daun ${ }^{* 4}$ \\
& 5. Jarak tanam ${ }^{* 5}$ \\
\hline
\end{tabular}

Sumber : ${ }^{* 1}$ Carpenter et al (1975), ${ }^{* 1}$ Grey dan Deneke $(1978),{ }^{* 2 * 5}$ DPU Diirjen Bina Marga (1996), ${ }^{* 3}$ Patra et al (2004), ${ }^{* 4}$ Nasrullah et al (2000) dalam skripsi Anita Desianti (2011)

Teknik penilaian fungsi tanaman sebagai penyerap polutan menggunakan rumus Key Perfomance Index (KPI) untuk memberi nilai sesuai dengan kriteria yang ada (Hidayat 2008). Tata cara evaluasi menggunakan rumus KPI dapat dilihat pada Tabel 8. Penilaian dilakukan untuk tiap jenis pohon. Tiap jenis pohon akan dipilih satu perwakilan untuk di evaluasi. Untuk masing-masing kriteria, diberikan penilaian dengan nilai antara 1 hingga 4 berdasarkan kesesuaian ciri fisik dan kondisi lapang pohon dengan kriteria penilaian, dimana nilai 1 berarti tidak sesuai, 2 berarti kurang sesuai, 3 berarti sesuai, dan 4 berarti sangat sesuai dengan kriteria penilaian. Nilai maksimal atau nilai ideal untuk tiap kriteria adalah 4. Nilai yang didapat dari setiap kriteria dijumlahkan kemudian dibandingkan dengan jumlah ideal atau nilai maksimum dari tiap kriteria penilaian. Hasil perbandingan kemudian diubah ke dalam bentuk persen untuk mendapatkan persentase nilai evaluasi.

$$
\text { Nilai Evaluasi }=\frac{\text { Jumlah total kriteria penilaian }}{\text { Jumlah total nilai ideal kriteria penilaian }} \times 100 \%
$$


Dari penilaian tersebut didapatkan hasil penilaian dalam bentuk persentase. Hasil penilaian tersebut kemudian dikelompokkan dalam empat kategori penilaian yaitu sangat sesuai, sesuai, kurang sesuai, tidak sesuai. Pengelompokkan hasil penilaian menggunakan 4 selang dimana nilai bobot sempurna yaitu $100 \%$ dibagi menjadi 4 selang sama besar, sebesar $20 \%$. Untuk penelitian ini, selang $40 \%$ terendah dikelompokkan dalam satu kategori tidak sesuai. Pembobotan $40 \%$ terendah untuk kategori tidak sesuai ditujukan untuk meningkatkan standar penilaian, dapat dilihat di Tabel 7 (Hidayat, 2008).

Tabel 7 Pengelompokan Persentase Pembobotan Aspek Fungsi Jalur Hijau Jalan

\begin{tabular}{ccll}
\hline & Nilai & Kelompok & Keterangan \\
\hline & 4 & Sangat sesuai & $>80 \%$ kriteria terpenuhi \\
3 & Sesuai & $61-80 \%$ kriteria terpenuhi \\
& 2 & Kurang sesuai & $41-60 \%$ kriteria terpenuhi \\
1 & Tidak sesuai & $\leq 40 \%$ kriteria terpenuhi
\end{tabular}

Sumber : Hidayat, 2008

Tabel 8 Evaluasi Menggunakan Metode KPI (Key Performance Index)

\begin{tabular}{|c|c|c|c|c|c|c|c|}
\hline No & Nama latin & $\begin{array}{l}\text { Nama } \\
\text { lokal }\end{array}$ & $\begin{array}{l}\text { K K K K K } \\
\begin{array}{llll}1 & 234\end{array}\end{array}$ & $\begin{array}{l}\mathrm{K} \\
\text { Nilai } \\
5 \text { aktual }\end{array}$ & $\begin{array}{l}\text { Nilai } \\
\text { standar }\end{array}$ & $\begin{array}{c}\text { Nilai } \\
\text { evaluasi } \\
(\%)\end{array}$ & Kesesuaian \\
\hline 1 & $\begin{array}{l}\text { Erythrina } \\
\text { cristagalli }\end{array}$ & $\begin{array}{l}\text { Dadap } \\
\text { Merah }\end{array}$ & $\begin{array}{lllll}3 & 4 & 4 & 3 & 4\end{array}$ & 18 & 20 & 90 & $\begin{array}{l}\text { Sangat } \\
\text { Sesuai }\end{array}$ \\
\hline 2 & $\begin{array}{l}\text { Ficus } \\
\text { benjamina }\end{array}$ & Beringin & $\begin{array}{lllll}4 & 2 & 3 & 4 & 2\end{array}$ & 15 & 20 & 75 & Sesuai \\
\hline 3 & Ficus lyrata & $\begin{array}{l}\text { Biola } \\
\text { Cantik }\end{array}$ & 44344 & 19 & 20 & 95 & $\begin{array}{l}\text { Sangat } \\
\text { Sesuai }\end{array}$ \\
\hline 4 & $\begin{array}{l}\text { Leucaena } \\
\text { leucocephala }\end{array}$ & Pete cina & 24334 & 16 & 20 & 80 & Sesuai \\
\hline
\end{tabular}

Keterangan : K1 "Kepadatan tajuk", K2 "Kombinasi tanaman", K3 "Ketipisan daun", K4 "Jumlah daun", K5 "Jarak tanam"

\section{Kepadatan Tajuk}

Kepadatan tajuk pohon mempengaruhi keefektifan penyaringan zat pencemar udara. Tajuk yang rapat dapat menyerap polusi lebih baik dibanding tajuk yang terbuka. Kepadatan tajuk diukur persentase dari total cahaya yang diblokir oleh pepohonan, dapat dilihat di Gambar 5 (Departemen Kehutanan, 2005).

Gambar 5 Ilustrasi Persentase Total Cahaya yang Diblokir Oleh Pepohonan Klasifikasi kerapatan tajuk pohon:

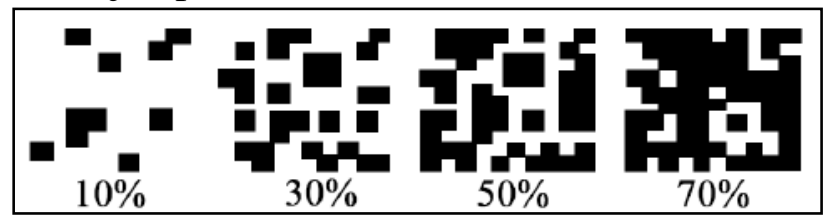

Nilai 1 : Sangat jarang 0-10\%,

Nilai 2 : Jarang $11-40 \%$,

Nilai 3 : Sedang $41-70 \%$,

Nilai 4 : Lebat 71-100\%. 


\section{Kombinasi Tanaman}

Vegetasi dengan ketinggian elemen tanaman yang bervariasi dapat menghalangi menyebarnya polutan. Kombinasi pohon dengan perdu, semak, dan groundcover memiliki luas permukaan yang lebih tinggi dan dapat menghalangi dan memperlambat penyebaran polutan, dapat dilihat di Gambar 6. Selain itu, untuk mendapatkan hasil reduksi yang maksimal, diperlukan tanaman penyangga dengan ketebalan yang cukup. Penanaman beberapa lapis pohon akan lebih efektif dalam mereduksi polusi.

Gambar 6 Kombinasi Penanaman Vegetasi pada Median Jalan (DPU Dirjen Bina

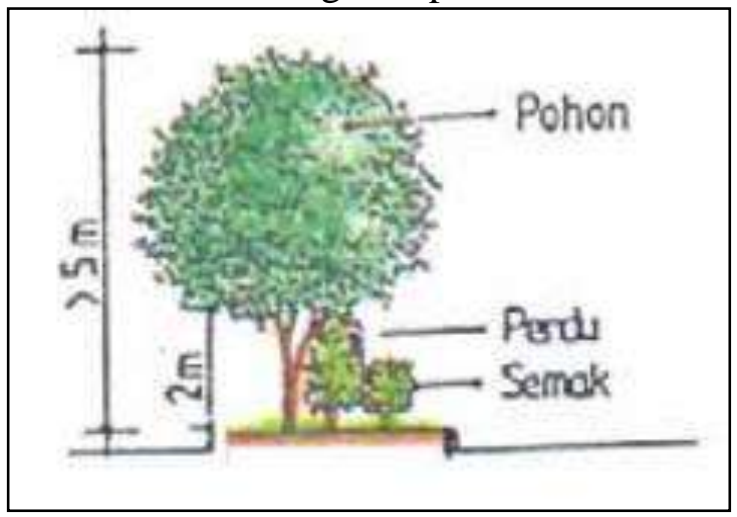

Marga, 1996)

Klasifikasi kombinasi tanaman:

Nilai 1: Hanya terdiri dari pohon,

Nilai 2: Terdiri atas beberapa lapis tanaman yang memilki kombinasi pohon dan perdu,

Nilai 3: Terdiri atas beberapa lapis tanaman yang memilki kombinasi pohon, perdu dan semak,

Nilai 4: Terdiri atas beberapa lapis tanaman yang memilki kombinasi pohon, perdu, semak dan groundcover.

\section{Ketipisan Daun}

Ketebalan daun mempengaruhi penyerapan gas. Daun yang tipis akan lebih mudah menyerap gas dan lebih baik untuk mereduksi zat pencemar udara. Penyerapan $\mathrm{NO}_{2}$ dipengaruhi oleh kerapatan stomata, tebal daun dan berat jenis daun. Semakin tinggi kerapatan stomata, semakin tipis ketebalan daun dan semakin kecil berat jenis daun maka semakin tinggi kemampuan dalam menyerap gas $\mathrm{NO}_{2}$ (Astra et al, 2004). Tebal dan tipisnya daun dipengaruhi oleh bentuk daging daun. Daging daun merupakan isi dari daun. Daging daun dibedakan menjadi tipis seperti selaput, tipis seperti kertas, tipis lunak, tipis perkamen/kaku, seperti kulit dan berdaging (Rosanti, 2012)

Klasifikasi jumlah daun:

Nilai 1: Seperti kulit (ex: daun nyamplung) dan Berdaging (ex: daun lidan buaya), Nilai 2: Tipis perkamen (ex: daun kelapa),

Nilai 3: Tipis lunak (ex: daun selada air),

Nilai 4: Tipis seperti selaput (ex: daun paku selaput) dan Tipis seperti kertas (ex: daun pisang). 


\section{Jumlah Daun}

Daun berperan penting dalam menyerap polutan udara. Jumlah daun pada suatu pohon dapat mempengaruhi penyerapan zat pencemar. Pohon dengan jumlah daun yang banyak lebih baik dalam penyerapan zat pencemar sehingga dapat mereduksi polusi dengan lebih baik. Metode estimasi jumlah daun hampir sama dengan cara metoda kepadatan tajuk, yang berbeda yaitu dilihat dari banyaknya cabang pada pohon tersebut. Menurut Departemen Kehutanan (2005) pohon dengan tajuk yang padat tentu akan memliki jumlah daun pohon yang banyak.

Klasifikasi jumlah daun pohon:

Nilai 1 : Sangat jarang 0-10\%,

Nilai 2 : Jarang $11-40 \%$,

Nilai 3 : Sedang $41-70 \%$,

Nilai 4 : Lebat $71-100 \%$.

\section{Jarak Tanam}

Jarak tanam yang rapat pada tanaman akan lebih baik untuk mereduksi polusi. Pohon yang ditanam rapat akan menjadi penghalang untuk penyebaran zat pencemar udara.

Klasifikasi jarak tanam rapat:

Nilai 1: jarak Vegetasi-Vegetasi berjauhan (tidak sesuai),

Nilai 2: jarak Vegetasi-Vegetasi tidak rapat (kurang sesuai),

Nilai 3: jarak Vegetasi-Vegetasi kurang rapat (sesuai),

Nilai 4: jarak Vegetasi-Vegetasi rapat (sangat sesuai).

Setelah dilakukan penilaian terhadap jalur hijau jalan, didapatkan nilai vegetasi jalan untuk fungsi fungsi sebagai tanaman penyerap polutan gas serta penentuan kelompok-kelompoknya seperti telah disebutkan sebelumnya. Hasil penilaian kemudian diolah menjadi sebuah pembahasan, Hasil pembahasan tersebut membahas jenis apa saja yang termasuk kedalam jenis vegetasi sebagai penyerap polutan gas, dimana vegetasi tersebut sesuai dengan kriteria yang telah diebutkan.

\section{Tahap Sintesis}

Tahap sintesis merupakan rekomendasi dari hasil studi potensi fungsi ekologis lanskap jalan lingkar Kota Bogor. Rekomendasi yang dihasilkan berupa spasial dan deskriptif. Rekomendasi spasial menunjukan peta hasil emisi CO2 di sepanjang jalan R3 Kota Bogor, sedangkan rekomendasi secara deskriptif menunjukan jenis vegetasi yang sesuai dengan kroteria penyerap polutan gas. Dari 2 hasil analisis tersebut, dihasilkan gambaran ilustrasi segmen lanskap jalur hijau terbaik yang dijadikan rekomendasi akhir. Rekomendasi yang diberikan terutama peningkatan kualitas lanskap jalan sebagai penyerap polutan gas di jalan R3 Kota Bogor yang digunakan sebagai contoh penanaman yang dapat diaplikasikan pada jalan lainnya. Rekomendasi diharapakan menjadi bahan masukan bagi pihak pemerintah Kota Bogor dalam pengembangan lanskap jalan di jalan R3 Kota Bogor. 


\section{KONDISI UMUM}

\section{Sejarah Kawasan}

Jalan R3 Kota Bogor merupakan jalan gabungan yang terdiri dari dua jalan sementara yaitu, Jalan Achmad Adnawijaya dan Jalan Kol. H. Ahmad Syam. Disebut jalan sementara karena jalan tersebut pembangunannya belum selesai. Jalan R3 Kota Bogor dbangun sejak tahun 2013 dan sampai dengan saat ini memiliki panjang $7.1 \mathrm{~km}$. Jalan ini direncanakan akan mencapai panjang 10,3 km dan berakhir di Jalan raya Tajur. Menurut UU RI no 13 tahun 2004, jalan R3 Kota Bogor dikategorikan sebagai jalan arteri sekunder dan diklasifikasi sebagai jenis jalan III C.

Jalan R3 Kota Bogor sementara ini melewati dua Kecamatan Kota Bogor, yaitu Kecamatan Bogor Utara dan Kecamatan Bogor Timur. Jalan ini awal mulanya direncānakan sebagai media pendukung untuk akses kendaraan karena banyaknya kawasān rumah tinggal di sepanjang jalan tersebut, namun karena banyaknya titik kemacetan di jalan-kalan besar di Kota Bogor, jalan ini juga difungsikan sebagai jalan alternatif untuk menghindari kemacetan. Jalan ini melintasi banyak cabang jalan yang menuju ke jalan-jalan besar lainnya di Kota Bogor, sehingga bukan hanya penduduk di sekitar Jalan R3 Kota Bogor saja yang melintasi namun juga banyak pemakai jalan yang sekedar melintas untuk memotong jalan. Jalan ini membentang dari daerah utara Kota Bogor hingga daerah timur Kota Bogor dan juga sejajar dengan jalan Raya Padjajaran.

Perkembangan Jalan R3 Kota Bogor cenderung menguat kearah usaha rumah makan, instansi, dan usaha-usaha lainnya setiap tahunnya. Jalan ini dianggap sebagai peluang usaha karena memiliki lokasi yang strategis dan banyaknya penduduk kota Bogor yang melintasi jalan tersebut. Pembangunan wilayah di sepajang jalan ini mencapai $13,27 \mathrm{~km}^{2}$ meliputi perumahan, perdangan, fasilitas komersial, serta saran dan prasarana (Kota Bogor dalam angka, 2016). Hasil penelitian dituliskan secara sistematis sesuai dengan data yang diperoleh dan analisis yang dilakukan. Bab Hasil dapat dibagi dalam beberapa subbab atau bahkan dalam beberapa bab dengan judul yang berbeda-beda sesuai dengan tujuan penelitian. Misal: dimulai dengan deskripsi daerah penelitian (setting) dan diikuti oleh beberapa bab untuk menjawab setiap tujuan penelitian. Hasil penelitian disajikan dengan jelas, terutama ketika memaparkan temuan penting.

\section{Letak, Luas, dan Aksesbilitas}

Jalan R3 Kota Bogor melewati dua Kecamatan Kota Bogor, yaitu Kecamatan Bogor Utara dan Bogor Timur. Jalan R3 Kota Bogor merupakan jalan lokal dengan tipe III C. Hal ini dikarenakan jalan tersebut memiliki ciri-ciri badan jalan Tebih dari 5 meter, kendaran yang melaju di jalan ini memiliki rata-rata kecepatan $40 \mathrm{~km} / \mathrm{jam}$ dan dalam klasifikasi kelas sumbu muatan kendaraan tidak lebih dari 8 ton.

Jalan R3 Kota Bogor melewati 5 kelurahan, dapat dilihat pada Gambar 7, yaitu Kelurahan Bantar Jati, Kelurahan Tegal Gundil, Kelurahan Tanah Baru, 
Kelurahan Baranang Siang dan Kelurahan Katulampa. Jalan ini juga dilalui aliran Sungai Ciparigi. Batas Jalan R3 Kota Bogor adalah sebagai berikut.

Batas utara : Kelurahan Bantar Jati

Batas timur : Kelurahan Tanah Baru, Kelurahan Katulampa, dan Tol Jagorawi

Batas selatan : Kelurahan Katulampa

Batas barat : Kelurahan Tegal Gundil, Kelurahan Baranang Siang dan Tol Jagorawi

Jalan R3 Kota Bogor merupakan jalan lokal yang srategis karena memiliki banyak akses langsung ke dalam jalan tersebut. Akses-akses tersebut meliputi, akses dari perempatan Jambu Dua, akses dari arah perumahan Bantar Jati, akses dari arah perumahan Bogor Baru, akses dari arah Kelurahan Cimahpar, akses dari jalan keluar alternatif Gerbang Tol Bogor dan dari arah Kelurahan Katulampa.

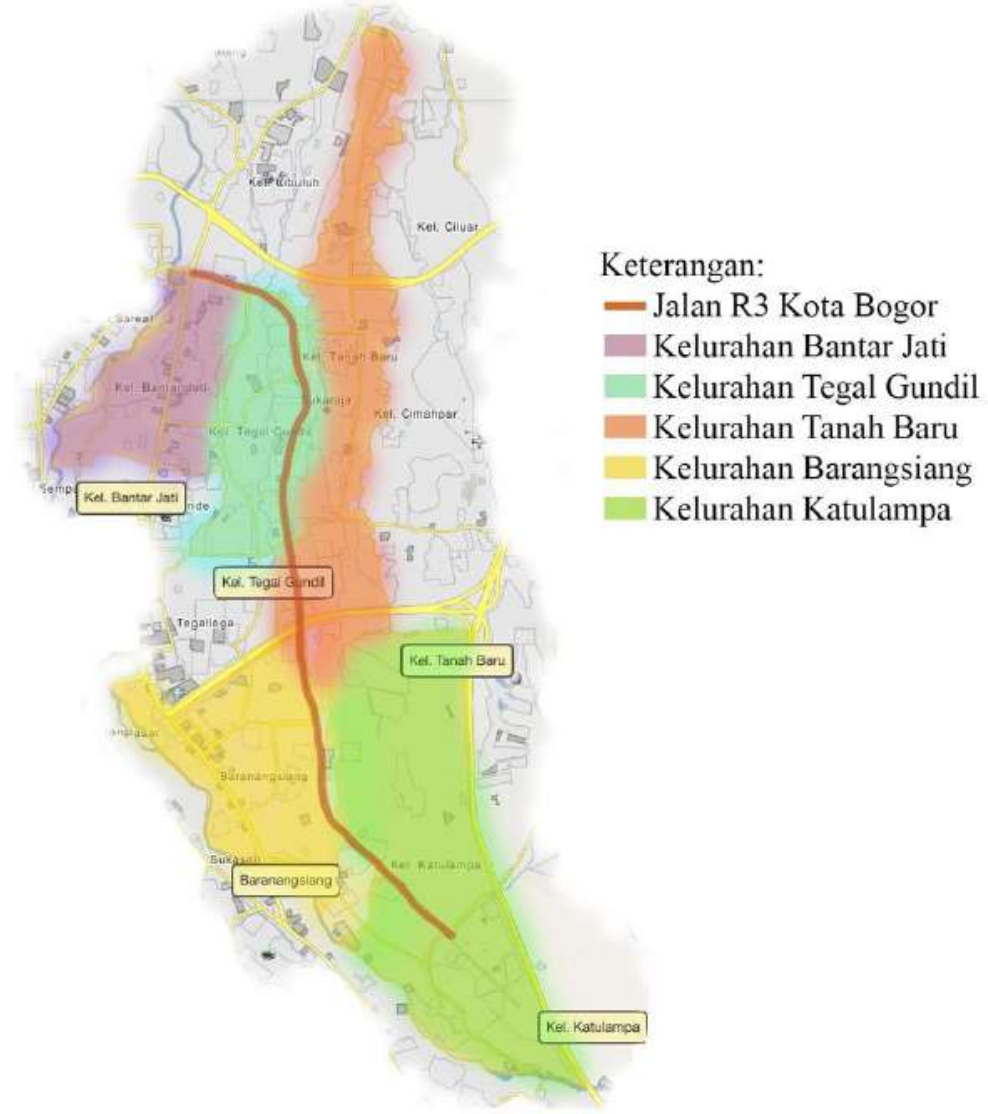

Gambar 7 Kelurahan-Kelurahan yang Dilewati Jalan R3 Kota Bogor

\section{Topografi dan Kemiringan Lahan}

Jalan R3 Kota Bogor berada di kawasan yang dikelilingi oleh pegununganpegunungan di Kota Bogor, Sehingga Jalan R3 Kota Bogor memiliki topografi jalan yang bergelombang. Menurut Badan Pusat Statistik (BPS) Kota Bogor, kelurahankelurahan di sepanjang jalan R3 Kota Bogor memiliki ketinggian topografi dan kemiringan lahan yang berbeda-beda. Hal itu disebabkan karena jalan R3 Kota Bogor berada di daerah perbukitan. Data-data ketinggian lahan dan kemiringan tahan dapat dilihat di Tabel 9 dan Tabel 10. 
Tabel 9 Ketinggian Lahan di Kelurahan-Kelurahan Sepanjang Jalan R3 Bogor

\begin{tabular}{|c|c|c|c|c|c|c|}
\hline \multirow{2}{*}{ No } & \multirow{2}{*}{ Kelurahan } & \multicolumn{4}{|c|}{ Ketinggian (mdpl) } & \multirow{2}{*}{$\begin{array}{c}\text { Jumlah } \\
\text { (ha) }\end{array}$} \\
\hline & & $0-200$ & $201-250$ & $251-300$ & $>300$ & \\
\hline \multicolumn{7}{|c|}{ Kecamatan Bogor Utara } \\
\hline 1 & antar Jati & 28,04 & 141,96 & 0,00 & 0,00 & 170,00 \\
\hline 2 & egal Gundil & 44,75 & 153,25 & 0,00 & 0,00 & 198,00 \\
\hline 3 & anah Baru & 80,88 & 141,38 & 10,74 & 0,00 & 233,00 \\
\hline \multicolumn{7}{|c|}{ Kecamatan Bogor Timur } \\
\hline & atulampa & 0,00 & 17,00 & 155,00 & 319,00 & 491,00 \\
\hline 2 & aranang Siang & 0,00 & 29,00 & 167,00 & 39,00 & 235,00 \\
\hline
\end{tabular}

Sumber: Kota Bogor Dalam Angka, 2016

Tabel 10 Kemiringin Lahan di Kelurahan-Kelurahan Sepanjang Jalan R3 Bogor

\begin{tabular}{|c|c|c|c|c|c|c|c|}
\hline \multirow[b]{2}{*}{ No $\frac{\overline{\bar{\lambda}}}{\overline{\bar{\sigma}}}$} & \multirow[b]{2}{*}{ Kelurahan } & \multicolumn{5}{|c|}{ Jenis Batuan (ha) } & \multirow[b]{2}{*}{$\begin{array}{l}\text { Jumlah } \\
\text { (ha) }\end{array}$} \\
\hline & & Datar & Landai & $\begin{array}{l}\text { Agak } \\
\text { curam }\end{array}$ & Curam & $\begin{array}{l}\text { Sangat } \\
\text { curam }\end{array}$ & \\
\hline \multicolumn{8}{|c|}{ Kecamatan Bogor Utara } \\
\hline $1 \mathrm{Ba}$ & ntar Jati & 36,00 & 111,00 & 0,00 & 22,50 & 0,50 & 170.00 \\
\hline $2 \mathrm{Te}$ & gal Gundil & 0,00 & 157,45 & 0,00 & 40,55 & 0,00 & 198.00 \\
\hline $3 \mathrm{Ta}$ & nah Baru & 0,00 & 231,25 & 0,00 & 1,75 & 0,00 & 233.00 \\
\hline \multicolumn{8}{|c|}{ Kecamatan Bogor Timur } \\
\hline $1 \mathrm{Ka}$ & tulampa & 81,45 & 399,35 & 0,00 & 10,20 & 0,00 & 491.00 \\
\hline $2 \mathrm{Ba}$ & rranang Siang & 50,10 & 153,55 & 0,00 & 27.90 & 3,45 & 235.00 \\
\hline
\end{tabular}

Sumber: Kota Bogor Dalam Angka, 2016

Jika dilihat dari Tabel 7 dan Tabel 8, Kelurahan-kelurahan di Kecamatan Bogor Utara memiliki ketinggian yang lebih rendah serta kemiringan lahan yang rata-rata landai. Sedangkankan Kelurahan-kelurahan di Kecamatan Bogor Timur yang cenderung lebih tinggi serta kemiringan lahan yang rata-rata juga landai. Ketinggian topografi di Kecamatan Bogor Utara memiliki dominan ketinggian 201 mdpl sampai 250 mdpl, sedangkan Kecamatan Bogor Timur memiliki dominan ketinggian 251mdpl sampai 300mdpl dan hingga lebih dari $300 \mathrm{mdpl}$. Angka-angka tersebut mengambarkan bahwa bentuk topografi di sepanjang Jalan R3 Kota Bogor memiliki permukaan lahan yang naik turun dan bergelombang.

\section{Tata Guna Lahan}

Tata guna lahan di sepanjang jalan R3 Kota Bogor terdiri atas beberapa macam pengguna lahan seperti perumahan, perdagangan, fasilitas komersial, serta sarana dan prasarana. Sarana dan prasarana dibagi menjadi beberapa jenis penggunaan lahan yaitu fasilitas khusus, jalan, interchange, fasilitas sosial dan fasilitas umum. Fasilitas yang bersifat pelayanan dibangun oleh pemerintah dan perusahaan swasta di beberapa tempat di sepanjang jalan sebagai sarana kegiatan sosial, rekreasi, dan olahraga.

Jalan R3 Kota Bogor merupakan jalan gabungan antara Jalan Achmad Adnawijaya dan Jalan Kol. Ahmad Syam. Wilayah di sekitar Jalan Achmad Adnawijaya merupakan wilayab yang umurnya lebih tua dibandingkan wilayah di 
sekitar Jalan Kol. Ahmad Syam. Jalan Achmad Adnawijaya sudah memiliki wilayah terbangun seperti perumahan, restoran/cafe, instantsi swasta, dan taman publik. Berbeda dengan wilayah terbangun di sepanjang Jalan Kol. Ahmad Syam, jalan ini lebih difokuskan untuk area perumahan dan pemerintah Kota Bogor mensentralasikan jalur di sepanjang jalan ini untuk area penjualan tanamantamanan hias serta jalur alternatif menuju wilayah Bogor Selatan apabila jalan utama yaitu Jalan Raya Padjajaran mengalami kemacetan.

Jika dilihat dari area terbangunnya, Jalan Achmad Adnawijaya cenderung lebih ramai dilewati masyarakat karena banyaknya area destinasi untuk dikunjungi. Jalan Kol. Ahmad Syam lebih dilalui masyarakat sebagai jalan alternatif karena banyaknya jalan cabang menuju daerah perkotaan di wilayah Bogor Selatan.

\section{Iklim}

Berdasarkan data iklim Badan Meteorologi, Geofisika dan Klimatologi (BMKG) Katulampa, jalan R3 Kota Bogor memiliki suhu, kelembaban, kondisi penyinaran matahari, dan angin kawasan yang berbeda-beda setiap bulannya. Data iklim tersebut dijabarkan pada Tabel 11.

Tabel 11 Data Iklim Kota Bogor Tahun 2016

\begin{tabular}{|c|c|c|c|c|c|}
\hline \multirow[b]{2}{*}{ Bulan } & \multirow{2}{*}{$\begin{array}{c}\text { Temperatur } \\
\text { Rata-rata } \\
\text { suhu } \\
\text { bulanan }\left({ }^{\circ} \mathrm{C}\right)\end{array}$} & \multirow{2}{*}{$\begin{array}{c}\text { Kelembaban } \\
\text { Rata-rata } \\
\text { kelembaban } \\
\text { bulanan }(\%)\end{array}$} & \multirow{2}{*}{$\frac{\text { Matahari }}{\underbrace{}_{(\text {Jam/Hari })}}$} & \multicolumn{2}{|c|}{ Angin } \\
\hline & & & & $\begin{array}{c}\text { Kecepatan } \\
\text { (Knots) }\end{array}$ & Arah \\
\hline Januari & 25.6 & 83.3 & 5.3 & 5.5 & $\mathrm{~N}$ \\
\hline Februari & 26.6 & 92 & 3.9 & 5.8 & $\mathrm{~N}$ \\
\hline Maret & 26.4 & 86.5 & 5 & 5.5 & $\mathrm{~N}$ \\
\hline April & 25.8 & 82.5 & 5.8 & 6.7 & $\mathrm{~N}$ \\
\hline Mei & 27 & 84.1 & 5.6 & 5.6 & $\mathrm{~N}$ \\
\hline Juni & 26.2 & 85.1 & 5.8 & 5.6 & $\mathrm{~N}$ \\
\hline Juli & 26.1 & 83.8 & 7 & 5.3 & $\mathrm{~N}$ \\
\hline Agustus & 26.1 & 82.9 & 6.6 & 5.6 & $\mathrm{~N}$ \\
\hline September & 26.2 & 84.1 & 5.9 & 5.9 & $\mathrm{~N}$ \\
\hline Oktober & 26 & 86.9 & 3.4 & 5.3 & $\mathrm{~N}$ \\
\hline November & 26 & 87.1 & 3.9 & 7.4 & $\mathrm{~N}$ \\
\hline Desember & 26 & 82.6 & 3.6 & 8.5 & $\mathrm{~N}$ \\
\hline Jumlah & 314.2 & 1021.4 & 62.4 & 73.1 & \\
\hline Rata-rata & 26.1 & 85.1 & 5.2 & 6 & \\
\hline
\end{tabular}

Sumber : Stasiun Klimatologi Dramaga, 2016

Suhu rata-rata bulanan dari bulan Januari 2016 sampai Desember 2016 adalah $26.1^{\circ} \mathrm{C}$ dengan suhu tertinggi sebesar $27^{\circ} \mathrm{C}$ pada bulan Mei 2016 dan suhu terendah sebesar $25.6{ }^{\circ} \mathrm{C}$ pada bulan Januari 2016. Kelembaban rata-rata kawasan dari Januari 2016 sampai Desember 2016 adalah 85.1\% dengan kelembabam tertinggi pada bulan Februari 2016 sebesar 92\% dan kelembaban terendah sebesar $82.5 \%$ pada bulan April 2016. Lama penyinaran matahari kawasan dari bulan Januari 2016 sampai Februari 2016 memiliki rata-rata sebesar 5.2 Jam/Hari dengan penyinaran maksimum pada bulan Juli 2016 sebesar $7 \mathrm{Jam} /$ Hari dan penyinaran 
terendah sebesar 3.4 Jam/Hari pada bulan Oktober 2016. Kecepatan angin rata-rata pada bulan Januari 2016 - Desember 2016 sebesar 6 knots dengan arah angin ke arah Utara dengan kecepatan angin maksimum sebesar 8.5 knots pada bulan Desember 2016 dan kecepatan angin terendah sebesar 5.3 knots pada bulan Juli dan Oktober 2016.

\section{Tanah}

Menurut Badan Pusat Statistik (BPS) Kota Bogor, seluruh wilayah Kota Bogor memiliki jenis tanah latosol coklat kemerahan. Tanah yang subur adalah tanah yang mempunyai profil yang dalam (kedalaman yang sangat dalam) melebihi $150 \mathrm{~cm}$, strukturnya gembur remah, $\mathrm{pH}$ 6-6,5, dan kandungan unsur haranya yang tersedia bagi tanaman adalah cukup dan tidak terdapat pembatas-pembatas tanah untuk pertumbuhan tanaman (Sutejo, 2002). Tanah latosol mempunyai beberapa karakteristik yaitu, tebal $130 \mathrm{~cm}$ hingga $500 \mathrm{~cm}$, ph 4,5-6,5, memiliki unsur hara dalam $\bar{r}$ entang rendah hingga tinggi, dan mempunyai daya tanah yang baik terhadap aliran air dan erosi tanah. Berdasarkan karakteristik tanah latosol tersebut, jenis tanah yang berada di seluruh wilayah Kota Bogor dapat dikatakan cuku subur.

Jenis tanah di kelurahan sepanjang jalan R3 Kota Bogor memiliki sifat tanah agak peka terhadap erosi, yang sebagian besar mengandung tanah liat dengan tekstur tanah halus (BPS Kota Bogor, 2016). Data-data kepekaan tanah terhadap erosi di kelurahan yang dilewati jalan R3 kota bogor dijabarkan pada Tabel 12 serta data tekstur tanah dapat dilihat pada Tabel 13.

Tabel 12 Kepekaan Tanah Terhadap Erosi di Kelurahan Sepanjang Jalan R3 Kota Bogor

\begin{tabular}{|c|c|c|c|c|c|}
\hline \multirow{2}{*}{ No } & \multirow{2}{*}{ Kelurahan } & \multicolumn{3}{|c|}{ Kepekaan tanah terhadap erosi } & \multirow{2}{*}{ Jumlah (ha) } \\
\hline & & Sangat Peka (ha) & Peka (ha) & Agak Peka (ha) & \\
\hline \multicolumn{6}{|c|}{ Kecamatan Bogor Utara } \\
\hline 1 & ntar Jati & 0,00 & 0,00 & 170,00 & 170,00 \\
\hline 2 & gal Gundil & 0,00 & 0,00 & 198,00 & 198,00 \\
\hline & ah Baru & 0,00 & 0,00 & 233,00 & 233,00 \\
\hline \multicolumn{6}{|c|}{ Kecamatan Bogor Timur } \\
\hline & tulampa & 0,00 & 0,00 & 491,00 & 491,00 \\
\hline 2 & anang Siang & 0,00 & 0,00 & 235,00 & 235,00 \\
\hline
\end{tabular}

Sumber: Kota Bogor dalam angka, 2016

Berdasarkan data dari Tabel 12, lima kelurahan yang di lewati jalan R3 Kota Bogor memiliki jenis tanah yang bersifat agak peka terhadap erosi. Hal ini sesuai dengan karakteristik jenis tanah latosol yang mempunyai daya tahan yang baik terhadap aliran air dan erosi tanah. Sehingga vegetasi yang ditanam di sepanjang Jalan R3 Kota Bogor dinilai cukup baik dalam segi pertumbuhan. 
Tabel 13 Tekstur Tanah di Kelurahan Sepanjang Jalan R3 Kota Bogor

\begin{tabular}{|c|c|c|c|c|c|c|}
\hline \multirow{2}{*}{$\mathrm{N}$} & \multirow[b]{2}{*}{ Kelurahan } & \multicolumn{4}{|c|}{ Tekstur Tanah } & \multirow{2}{*}{$\begin{array}{c}\text { Jumlah } \\
\text { (ha) }\end{array}$} \\
\hline & & Halus (ha) & Sedang (ha) & $\begin{array}{c}\text { Agak Kasar } \\
\text { (ha) }\end{array}$ & Kasar (ha) & \\
\hline \multicolumn{7}{|c|}{ Kecamatan Bogor Utara } \\
\hline 1 & Bantar Jati & 170,00 & 0,00 & 0,00 & 0,00 & 170,00 \\
\hline 2 & Tegal Gundil & 198,00 & 0,00 & 0,00 & 0,00 & 198,00 \\
\hline 3 & Tanah Baru & 233,00 & 0,00 & 0,00 & 0,00 & 233,00 \\
\hline \multicolumn{7}{|c|}{ Kecamatan Bogor Timur } \\
\hline 1 & Katulampa & 491,00 & 0,00 & 0,00 & 0,00 & 491,00 \\
\hline 2 & Baranang Siang & 202,79 & 0,00 & 32,21 & 0,00 & 235,00 \\
\hline
\end{tabular}

Sumber : Kota Bogor dalam angka, 2016

Hampir seluruh kelurahan yang dilewati jalan R3 Kota Bogor memiliki tekstur tanah dengan tekstur halus, kecuali kelurahan Barang Siang dimana dari total $235 \mathrm{ha}$, tanah yang bertekstur halus seluas 202,79 dan yang bertektur agak kasar 32,21 ha. Tanah dengan tekstur halus memiliki kemampuan proses penyerapan unsur-unsur hara yang lebih besar dibandingkan tanah dengan tekstur kasar, sehingga tanaman akan lebih subur jika berada di tanah dengan tekstur yang halus.

\section{Vegetasi}

Vegetasi yang terdapat di sepanjang jalan R3 Kota Bogor digolongkan sebagai vegetasi pengarah jalan dan vegetasi ruang terbuka hijau. Vegetasi pengarah jalan ditanaman di tepi jalan dan median jalan, vegetasi pengarah jalan mendominasi di sepanjang jalan R3 Kota Bogor. Vegetasi ruang terbuka hijau terdapat di beberapa median jalan pada Jalan R3 Kota Bogor. Vegetasi pada Jalan Achmad Adnawijaya memiliki umur penanaman yang lebih dini dibandingkan vegetasi di Jalan Kol. Ahmad Syam. Penanaman yang dini karena umur jalan yang lebih tua, berbeda dengan vegetasi Jalan Kol. Ahmad Syam yang dimana jalan baru dibangun sejak tahun 2014.

Rencana penanaman di sepanjang jalan R Kota Bogor dikelola oleh Dinas Perumahan dan Permukiman Kota Bogor yang bekerja sama dengan masyarakat sekitar. Sehingga pola vegetasi di beberapa tempat tidak selalu seragam. Pemerintah Kota Bogor juga sengaja mensentralisasikan penjualan tanaman hias di sepanjang Jalan Kol. Ahmad Syam. Hal itu bertujuan untuk meningkatkan elemen hijau di sepanjang serta relokasi penjualan tanaman hias dari Jalan Padjajaran agar lebih rapih dan mudah di kontrol.

Jenis vegetasi yang terdapat di sepanjang jalan terdiri dari pohon tinggi, pohon sedang, pohon rendah, perdu tinggi, perdu sedang, perdu rendah, semak tinggi, semak sedang, semak rendah, groundcover dan rumput. Pola penanaman pada tepi jalan terdiri dari kombinasi pohon dan rumput. Sedangkan pola penanaman pada median jalan berupa kombinasi pohon, semak, groundcover, rumput serta adanya ruang terbuka hijau di beberapa median jalan. 


\section{Jalan R3 Kota Bogor}

\section{Lokasi dan Dimensi}

Jalan R3 Kota Bogor merupakan gabungan jalan dari Jalan Achmad Adnawijaya dan Jalan Kol. Ahmad Syam. Jalan ini merupakan jalan proyek perencanaan Pemerintah Kota Bogor sejak tahun 2013 sebagai jalan alternatif dari Bogor Utara menuju Bogor Selatanakan. Sementara ini Jalan R3 Kota Bogor sudah terbangun sepanjang 7.1 Km. Jika dilihat dari peta jalan ini berdampingan dengan Jalan Raya Padjajaran.

Menurut UU RI no 13 tahun 2004, jalan R3 Kota Bogor dikategorikan sebagai jalan arteri sekunder dan diklasifikasi sebagai jenis jalan III C. Jalan R3 Kota Bogor terdiri dari dua jalur jalan yang masing-masing memiliki lebar jalan $5 \mathrm{~m}$, lebar tepi jalan $1 \mathrm{~m}$ dan memiliki 3 jenis lebar median yang berbeda-beda yaitu $1 \mathrm{~m}, 3 \mathrm{~m}$, dan $12 \mathrm{~m}$. Ilustrasi dimensi jalan yang dibuat oleh penulis berdasarkan dengan ukuran lapang yang ada dapat dilihat pada Gambar 8, Gambar 9 dan Gambar 10. Kondisi Topografi menurut Badan Pusat Statistik Kota Bogor, Jalan R3 Kota Bogor memilki topografi yang bergelombang dan memiliki perbedaan ketinggian yang beragam.

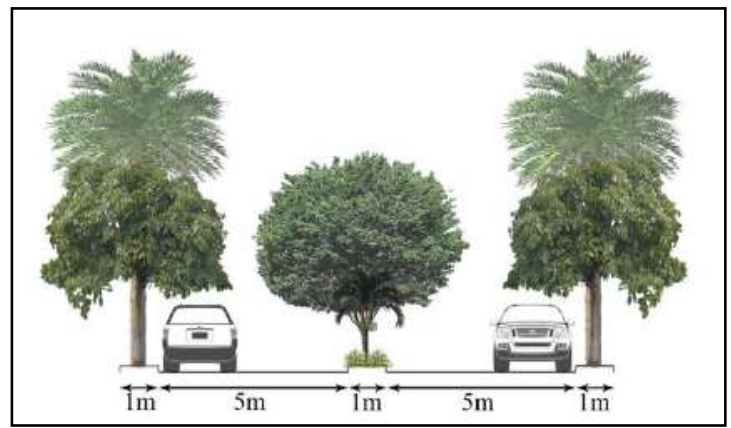

Gambar 8 Ilustrasi Dimensi Jalan R3 Kota Bogor Dengan Lebar Median 1m

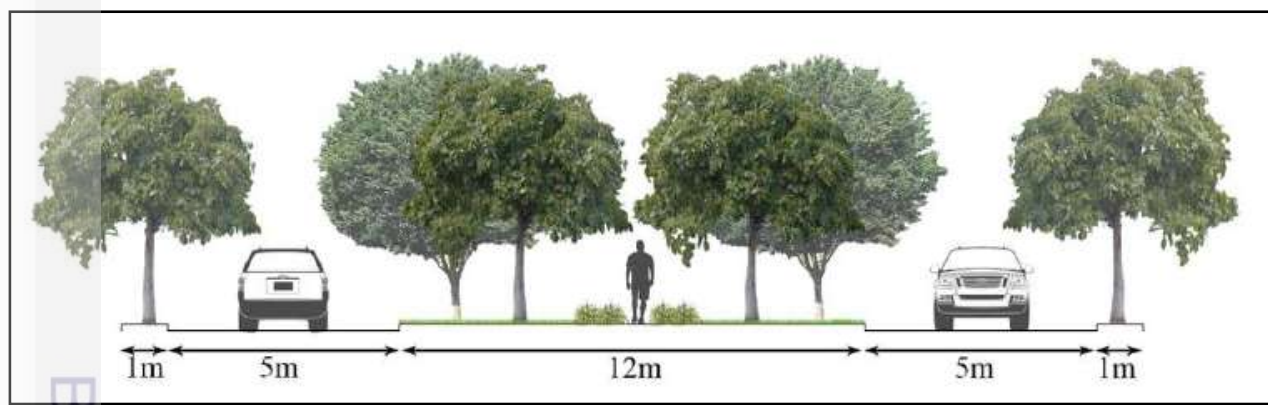

Gambar 9 Ilustrasi Dimensi Jalan R3 Kota Bogor Dengan Lebar Median 12m

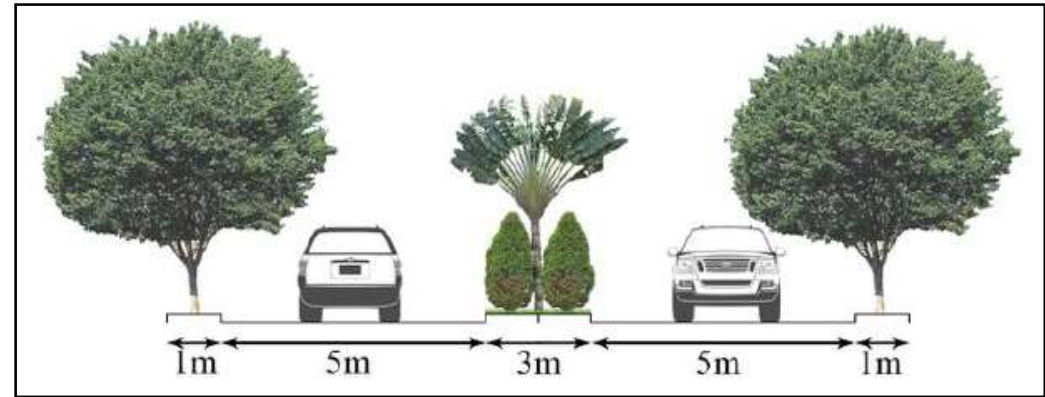

Gambar 10 Ilustrasi Dimensi Jalan R3 Kota Bogor Dengan Lebar Median 3m 


\section{Elemen Pembentuk Jalan}

Elemen pembentk jalan R3 Kota Bogor anatara lain elemen tanaman dan elemen penunjang. Jalan bagi suatu kawasan juga berfungsi sebagai ruamg terbuka hijau. Dengan demikian, tanaman menjadi salah satu elemen penting yang membentuk lanskap jalan. Elemen tanaman yang terdapat pada jalan R3 Kota Bogor anatara lain pohon, semak, groundcover, dan rumput, Elemen tanaman pada suatu lanskap jalan selain memberikan kualitas visual pada jalan juga memiliki fungsi-fungsi lain seperti pengarah, kontrol polusi, kontrol silau, dan peneduh. Selain tanaman, terdapat elemen penunjang yang berupa kelengkapan jalan. Elemen penunjang pada jalan R3 Kota Bogor antara lain saluran drainase, lampu jalan, lampu lalu lintas, perkerasan dan marka jalan. Contoh elemen penunjang pada jalan R3 Kota Bogor ditunjukan pada Gambar 11(a) dan Gambar 11(b).

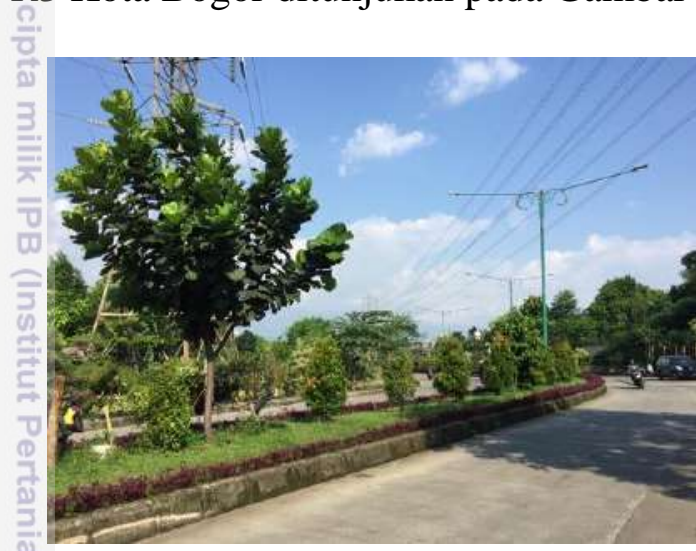

(a)

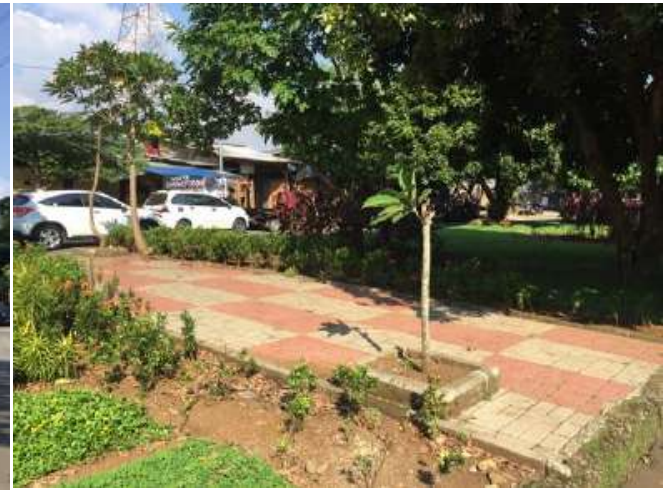

(b)

Gambar 11 (a) Lampu Jalan, dan (b) Perkerasan

\section{Tata Hijau Jalan}

Penanaman vegetasi di sepanjang Jalan R3 Kota Bogor menerapkan fungsi tanaman sebagai pengarah jalan, peneduh, kontrol polusi dan estetika. Tata hijau pada lanskap jalan R3 Kota Bogor didominasi oleh penanaman pohon mahoni (Swietenia mahagoni) dan pucuk merah (Syzygium oleina). Kedua jenis tanaman ini dipilih untuk memberikan kenyamanan bagi pengguna jalan agar jalan teduh dan ramah lingkungan. Terdapat juga jenis-jenis pohon lain yaitu pohon berkayu, pohon berbunga, dan palem-paleman. Beberapa contoh tanaman tersebut yaitu bintaro (Cerbera manghas), biola cantik (Ficus lyrata), Kamboja (Plumeria rubra), dan palem putri (Veitchia merilii). Beberapa lokasi yang menjadi gambran contoh tata hijau Jalan R3 Kota Bogor dapat dilihat di Gambar 12.

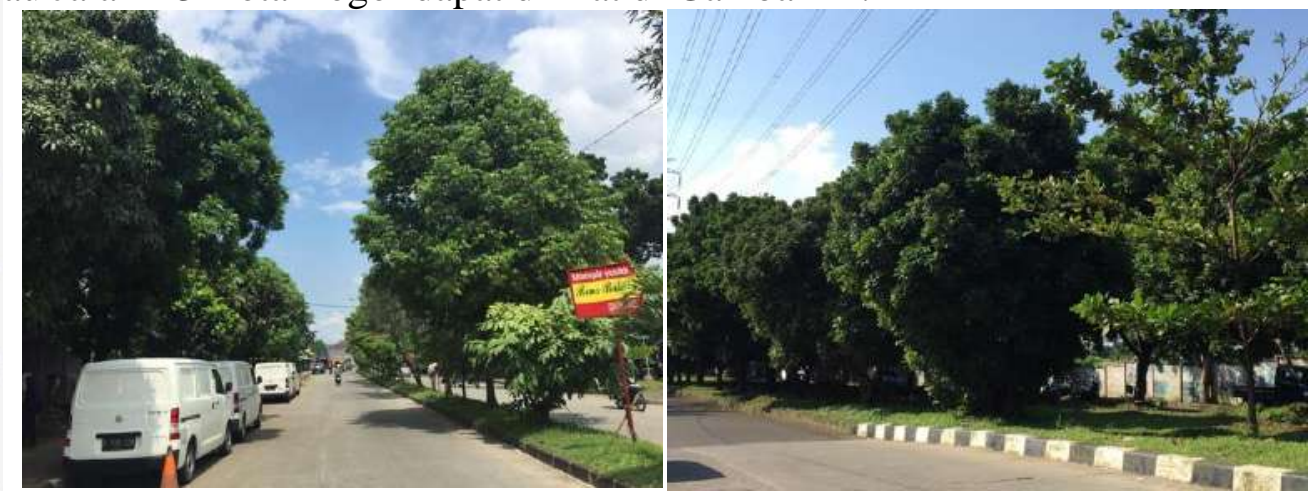

Gambar 12 Tata Hijau Jalan R3 Kota Bogor 
Selain pohon, berbagai jenis elemen tanaman juga terdapat di tata hijau jalan R3 Kota Bogor. Elemen-elemen tersebut yaitu semak, perdu, groundcover, dan rumput. Kombinasi pohon, perdu, semak dan rumput dilakukan untuk memaksimalkan fungsi vegetasi lanskap dalam mereduksi bising, menyerap polutan, menjerap partikel, dan pagar alami. Penanaman groundcover dilakukan di beberapa median dengan membentuk pola-pola yang menarik. Pola penanamn tersebut dapat dilihat di Gambar 13.

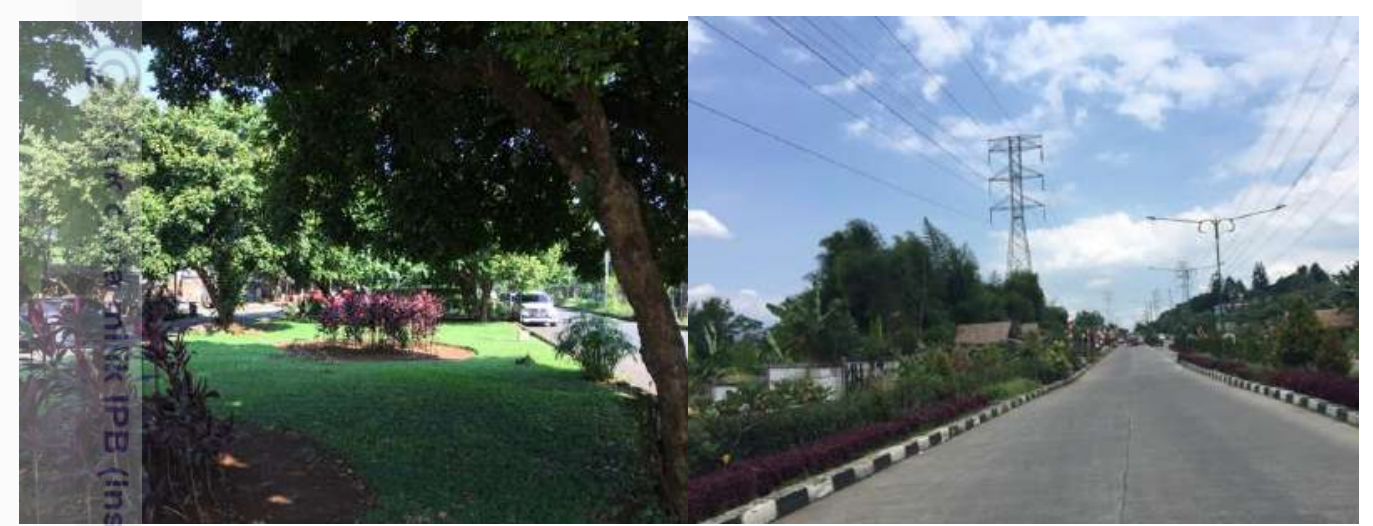

Gambar 13 Pola Penanaman Groundcover di Median Jalan

\section{Jumlah Kendaraan}

Jumlah kendaraan di Kota Bogor diketahui terus meningkat setiap tahunnya. Menurut data dari Badan Pusat Statistik Jawa Barat jumlah kendaraan di Kota Bogor pada tahun 2017 meningkat sebesar 20\% dibandingkan dengan jumlah kendaraan di tahun 2014. Jumlah kendaraan per tahun dapat dilihat pada tabel 14 .

Tabel 14 Jumlah Kendaraan di Kota Bogor

\begin{tabular}{cccc}
\hline Tahun & Mobil & Motor & Total \\
\hline 2014 & 84969 & 310097 & 394566 \\
2015 & 93874 & 341670 & 434044 \\
2016 & 96741 & 360923 & 457664 \\
2017 & 100086 & 373501 & 473587 \\
\hline
\end{tabular}

Sumber : Badan Pusat Statistik Jawa Barat, 2017

Jika dilihat dari Tabel 12, juumlah kendraan di Kota Bogor meningkat setiap tahunnya. Jumlah kendaraan roda dua/motor memiliki angka kenaikan yang sangat tinggi. Hal ini menyimpulkan bahwa Kota Bogor memiliki potensi meningkatnya jumlah kendaraan di tahunn-tahun berikutnya. 


\section{PEMBAHASAN}

\section{Lanskap Jalan R3 Kota Bogor}

Penelitian ini dilakukan pada jalan R3 Kota Bogor. Jalan ini merupakan jalan lokal berklasifikasi IIIC yang berada di Kota Bogor. Jalan R3 Kota Bogor memiliki panjang sekitar $7.1 \mathrm{~km}$. Jalan ini berawal dari perempatan jambu dua hingga berakhir di pertigaan jalan Kol. Ahmad Syam. Jalan ini merupakan gabungan dua jalan yaitu jalan Ahcmad Adnawijaya dan jalan Kol. Ahmad Syam. Jalan ini melewati banyak persimpangan jalan yaitu pertigaan bantar jati, arah keluar alternatif gerbang tol bogor, arah menuju perumahan villa duta, hingga arah menuju Jalan Raya Tajur. Jalan R3 Kota Bogor dibatasi oleh tol Jagorawi pada bagian barat dan timur. Bagian Utara jalan dibatasi oleh Kelurahan Bantar Jati. Bagian timur jalan dibatasi Kelurahan Tanah Baru dan Kelurahan Katulampa. Bagian selatan jalan dibatasi kelurahan Katulampa. Bagian barat jalan dibatasi Kelurahan Tegal Gundil dan Kelurahan Baranang Siang.

Tata guna lahan di sekitar jalan R3 Kota Bogor di dominasi oleh perumahan dan cafe/restoran yang tersebar di sepanjang jalan tersebut. Di sekitar jalan tersebut juga terdapat instansi swasta, fasilitas komersil, serta ada fasilitas umum contohnya taman corat coret di persimpangan bantar jati. Kecuali tata guna lahan di sekitar jalan Kol. Ahmad Syam menuju Kelurahan Katulampa, pembangunan di wilayah tersebut difokuskan untuk perumahan-perumahan baru serta adanya penjualan tanaman-tanaman hias di sepanjang jalan.

Kendaraan yang melintas di jalan R3 Kota Bogor bukan hanya penduduk sekitar saja yang melintas, namun juga masyarakat dari luar kawasan. Hal itu terjadi karena jalan R3 Kota Bogor merupakan jalan alternatif yang memiliki banyak cabang jalan, banyaknya destinasi untuk berkunjung di sepanjang jalan Achmad Adnawijaya dan limpasan dari arah pintu keluar alternatif gerbang tol Bogor. Hal tersebut membuat kondisi lalu lintas kendaraan menjadi padat terutama di hari libur, kondisi kemacetan dapat dilihat pada Gambar 14. Berbeda dengan kondisi lalu lintas di jalan Kol. Ahmad Syam, jalan ini cenderung lebih sedikit kendaraan yang melintas. Hal itu terjadi karena jalan Kol. Ahmad Syam merupakan jalan baru selesai pembangunannya, sehingga minim lokasi destinasi untuk didatangi. Biasanya masyarakat yang menggunakan jalan ini hanya melintas jalan menuju daerah Bogor Selatan, apabila jalan utama yaitu Jalan Raya Padjajaran mengalami kemacetan.

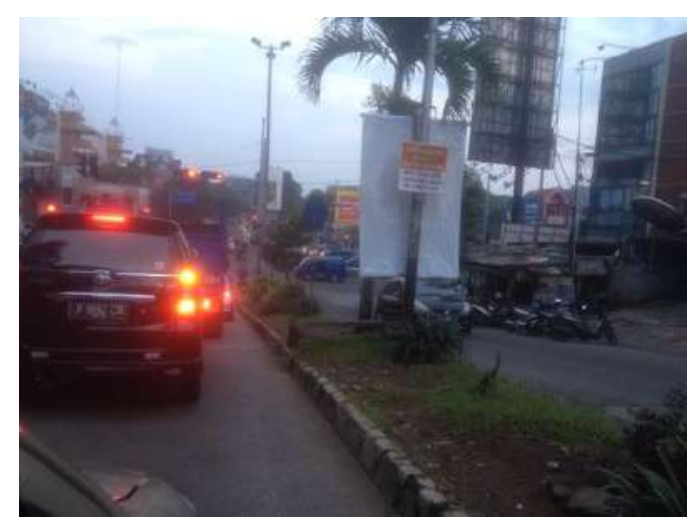

Gambar 14 Kondisi Lalu Lintas Padat Menuju Perempatan Jambu Dua 
Alat transportasi atau kendaraan bermotor, memiliki beberapa dampak negatif bagi lingkungan sekitarnya, antara lain kebisingan dan polusi udara. Pembakaran bahan bakar pada alat transportasi merupakan salah satu sumber utama pencemar udara. Pembakaran bahan bakar alat transportasi antara lain menimbulkan gas timbal $(\mathrm{Pb})$, oksida karbon (COx), oksida nitrogen (NOx), dan oksida sulfida (SOx) (Fandeli, 2009). Peningkatan jumlah kendaraan dikhawatirkan akan menambahkan tingkat zat pencemar. Dampak tersebut perlu diperhatikan oleh pengelola kawasan. Dampak polusi udara dapat diminimalkan dengan pengadaan ruang terbuka hijau (RTH).

Jalan R3 Kota Bogor saat ini sudah ditanami vegetasi di median dan tepi di sepanjang jalan, selain itu juga terdapat ruang terbuka hijau pada beberapa median jalan. Adanya ruang terbuka hijau serta penanaman vegetasi yang rapat memiliki nilai tambah dalam fungsi ekologis dalam lingkungan salah satunya dapat mengurangi pencemaran udara. Adanya vegetasi yang rapat (Gambar 15a) serta ruang terbuka hijau (Gambar 15b) pada jalan R3 Kota Bogor diharapkan dapat membätu dampak polusi akibat kendaraan bermotor.

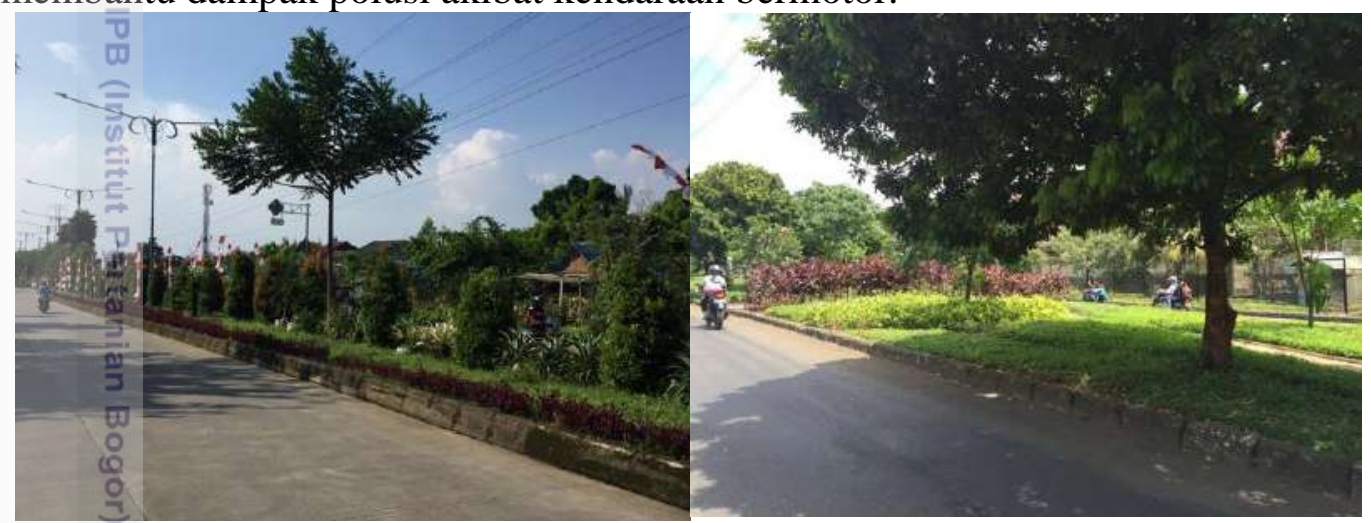

(a)

(b)

Gambar 15 (a) Penanaman Vegetasi Rapat, dan (b) Ruang Terbuka Hijau di Salah Satu Median

\section{Identifikasi Karakteristik Jalur Hijau Jalan}

Jalan R3 Kota Bogor merupakan salah satu jalan utama di Kota Bogor, jalan ini merupakan jalan arteri sekunder yang menghubungkan beberapa daerah di Kota Bogor. Jalan ini terbentang dari daerah Bogor Utara hingga ke Bogor Selatan. Lanskap jalan pada jalan ini lebih memperhatikan fungsi vegetasi sebagai peneduh dan pengarah jalan, sehingga memberikan kesan nyaman bagai penduduk atau masyarakat yang melintas. Jalan R3 Kota Bogor dilengkapi jalur hijau jalan.

Bentuk Jalur Hijau Jala di sepanjang jalan R3 Kota Bogor memiliki topografi yang bergelombang dan kemiringan yang rata-rata landai. Jalan R3 Kota Bogor juga dibentuk mengikuti bentuk topografi yang bergelombang, karena kawasan di sepanjang jalan tersebut tidak memilki kemiringan yang curam sehingga bentukan tepi dan median mengikuti kemiringan jalan. Tanah kawasan secara umum kaya unsur hara dan memilki tingkat kesuburan yang cukup.

Secara umum, jalur hijau di sepanjang jalan ditanami jenis vegetasi yang estetis. Vegetasi yang ditanam pada lanskap jalan tersebut lebih di tata sebagai vegetasi pengarah jalan. Pola-pola vegetasi yang estetis hanya ada di beberapa 
median di sepanjang jalan tersebut. Pada lanskap jalan, jalur hijau selain ditunjukan untuk menambah visual jalan juga untuk memenuhi beberapa fungsi lain fungsi peneduh, penyerap polusi, peredam kebisingan, pemecah angin, pembatas pandang, dan penahan silau lampu kendaraan. Vegetasi di jalan R3 Kota Bogor ditanam pada tepi jalan, median jalan dan pulau jalan.

\section{Jalur Tanaman Tepi Jalan}

Penanaman pada tepi jalan R3 Kota Bogor hanya di dominasi oleh vegetasi pepohonan dan rumput, vegetasi yang dipilih yaitu vegetasi berkayu dan berkanopi padat (Gambar 16). Pada tepi jalan di sepanjag jalan R3 Kota Bogor terdapat jenis pohon seperti pohon mahoni (Swietenia mahagoni), pohon bintaro (Cerberas manghas), dan pohon biola cantik (Ficus lyrata), pemilihan jenis pohon tersebut digunakan sebagai peneduh karena memiliki tajuk yang lebar. Di beberapa tepi juga terdapat pohon jenis palem raja, pemilihan jenis pohon tersebut untuk menambah nilai estetis.

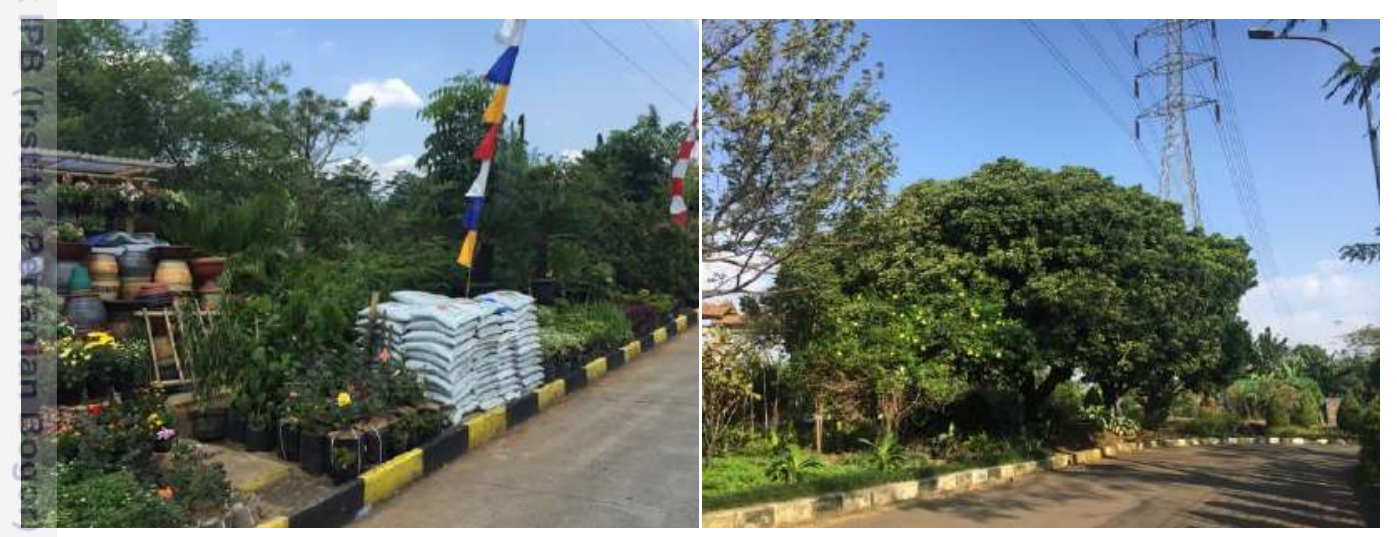

Gambar 16 Pohon pada Tepi Jalan

\section{Median Jalan}

Median merupakan jalur pemisah antara lajur-lajur jalan dan dapat berbentuk taman maupun non taman (Peraturan Menteri Pekerjaan Umum No. 05 Tahun 2008). Pada jalan R3 Kota Bogor, median jalan merupakan bagian dari dari jalur hijau jalan. Median jalan pada jalan ini memisahkan dua lajur kendraan dan berbentuk taman. Jalur hjau pada median jalan R3 Kota Bogor menggunakan vegetasi pengarah jalan. Fungsi median jalan terutama sebagai pengarah jalan dan penghalau silau.

Median jalan juga dapat menambah nilai keindahan lanskap jalan. Selain untuk memenuhi aspek fungsional, median jalan juga dapat menambahkan nilai estetika pada jalan tersebut. Jenis vegetasi yang terdapat pada median jalan di jalan R3 Kota Bogor lebih di dominasi oleh jenis vegetasi estetis. Beberapa jenis vegetasi seperti jenis palem dan pohon berbunga. Selain jenis pohon, pada median juga di tanam berbagai jenis semak dan groundcover. Penanaman pada median jalan R3 Kota Bogor memilki pola penanaman dengan kombinasi pohon, perdu, semak, groundcover dan rumput (Gambar 17a). Namun, pada beberapa median jalan hanya memiliki kombinasi pohon, perdu dan rumput (Gambar 17b). Pola penanaman tersebut sesuai dengan kriteria vegetasi sebagai penyerap polutan gas Pada beberapa median juga terdapat elemen hardscape seperti jalan setapak. 


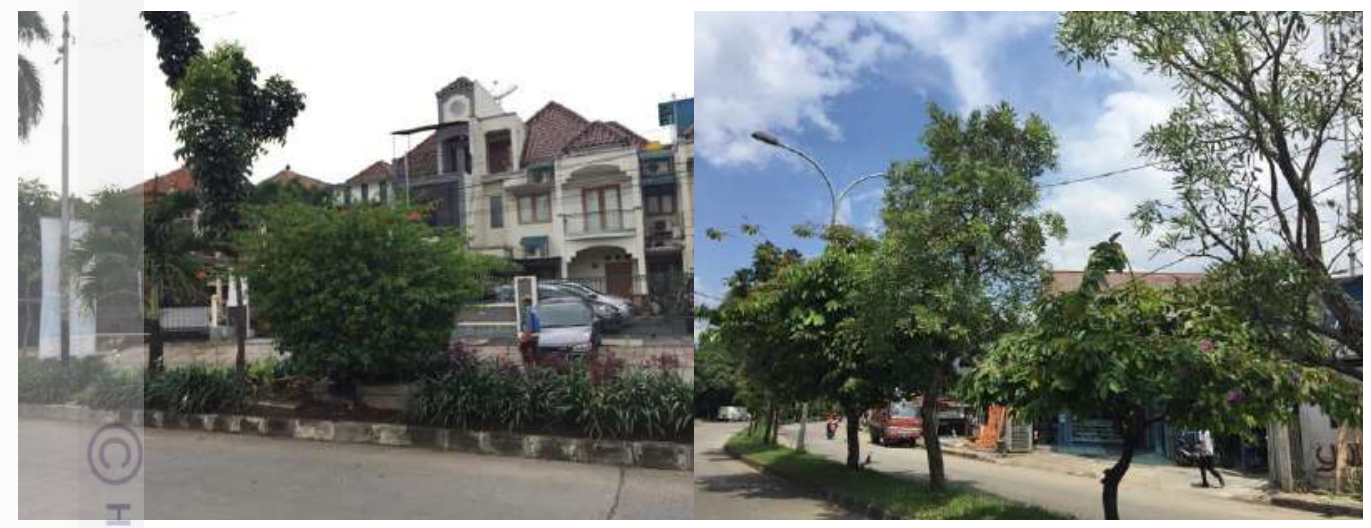

(a)

(b)

Gambar 17 (a) Median Dengan Kombinasi Pohon, Perdu, Semak, Groundcover, dan Rumput, dan (b) Median Dengan Kombinasi Pohon, Perdu dan Rumput

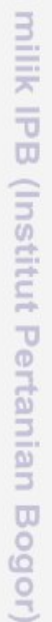

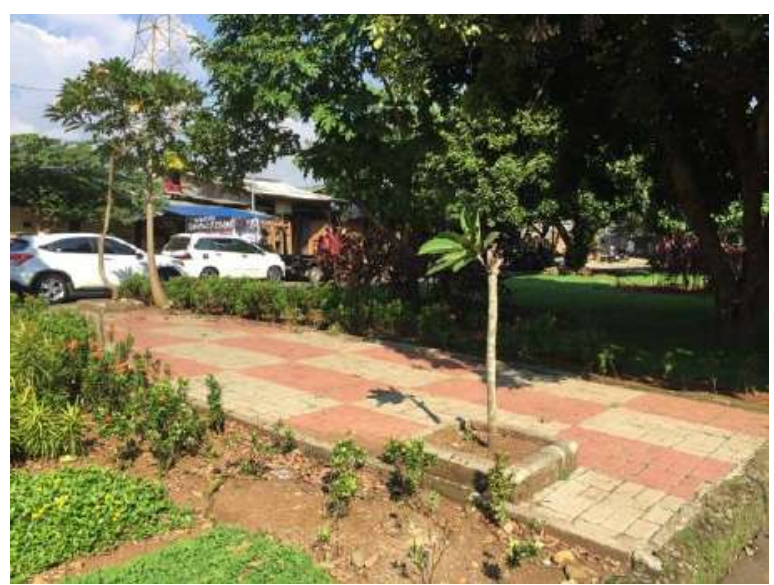

Gambar 18 Perkerasan pada Median Jalan R3 Kota Bogor

\section{Traffic Islands (pulau jalan)}

Selain pada tepi dan median, ada juga bagian jalur hijau jalan yang disebut pulau jalan (Gambar 19). Pulau jalan memiliki fungsi sebagai pengarah lalu lintas. Pulau jalan pada jalan R3 Kota bogor memiliki lahan yang sempit. Penanaman pada pulau jalan tersebut hanya jenis vegetasi pohon dan rumput. Pulau jalan pada jalan ini berfungsi sebagai pengontrol lalu lintas pertemuan jalan lintas utama dengan jalan dari arah perumahan.

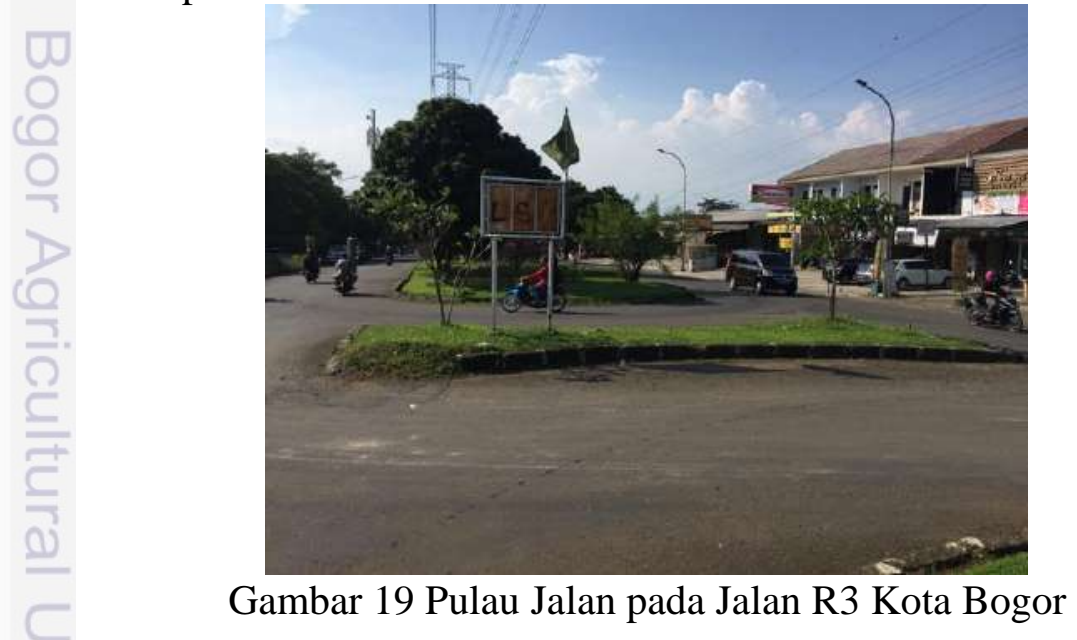




\section{Identifikasi Vegetasi Jalur Hijau Jalan}

\section{Jenis Pohon di Jalan R3 Kota Bogor}

Secara umum, aspek fungsional vegetasi lebih mendominasi di bandingkan aspek estetika di sepanjang Jalan R3 Kota Bogor. Hal ini ditunjukan dengan dominannya vegetasi yang memiliki fungsi sebagai vegetasi pengarah jalan dan vegetasi peneduh. Beberapa vegetasi juga memliki aspek estetik, namun vegetasivegetasi dengan nilai estetik tidak ditanam menyebar luas di sepanjang jalan R3 Kota Bogor. Vegetasi pada lanskap jalan ini ditunjukan untuk memberikan udara segar dan kontrol polusi.

Penanaman vegetasi pada jalur hijau jalan dilakukan pada median jalan, tepi jalan, dan traffic islands. Dari hasil pemetaan dengan survei langung dan data dari Dinas Perumahan dan Permukiman Kota Bogor jumlah pohon yang dipetakaan mencapai 2734 pohon. Pohon yang dipetakan yaitu pohon dengan tinggi lebih dari $2 \mathrm{~m}$, dan letaknya terutama pada median, tepi dan traffic islands. Berdasarkan hasil survei lapang dan data Dinas Perumahan dan Permukiman Kota Bogor, pada jalur hijau jalan R3 Kota Bogor terdapat 27 jenis pohon. Luasan penanaman vegetasi yang ada di jalan R3 Kota Bogor sesuai dengan Undang-Undang Republik Indonesia nomor 26 tahun 2007 mengenai ruang terbuka hijau. RTH harus memiliki $30 \%$ dari total area. Untuk lebih jelasnya dapat dilihat pada Lampiran 2.

Berbagai jenis pohon pada jalur hijau jalan R3 Kota Bogor antara lain jenis pohon berkayu, pohon berbunga, pohon konifer dan jenis palem. Pohon berkayu banyak berada pada median jalan seperti biola cantik (Ficus lyrata), mahoni (Swietenia mahagoni) dan bintaro (Cerbera manghas). Pohon berbunga seperti kamboja (Plumeria sp.) dan terung bunga ungu (Solanum melongena), jenis tersebut terdapat di median dan tepi jalan. Pohon konifer yang berada di jalan R3 Kota Bogor memilki jumlah yang sedikit dan berada di tepi jalan, jenis pohon konifer yang berada di sepanjang jalan seperti pinus (Pinus merkusii) dan cemara Norfolk (Araucaria heteropylla). Jenis palem-paleman di sepanjang jalan R3 Kota Bogor banyak digunakan di tepi jalan dan terutama di median jalan, jenis palem yang berada jalan ini yaitu palem raja (Roystonea regia), palem putri (Veitchia merilii) dan palem kipas (Livistona chinensis).

Jenis pohon yang mendominasi pada jalur hijau jalan R3 Kota Bogor yaitu mahoni (Swietenia mahagoni), pucuk merah (Syzgium oleina) dan bintaro (Cerbera manghas). Ketiga jenis ini banyak ditanam di median jalan. Jenis lain yang cukup banyak yaitu biola cantik (Ficus lyrata), beringin (Ficus benjamina), angsana (Pterocarpus), kamboja (Plumeria sp.), dadap merah (Erythrina cristagalli), mangga (Mangifera indica), dan tabebuya kuning (Tabebuia rosea). Beberapa jenis pohon yang dominan di median jalan memang difungsikan sebagai pohon peneduh, pengarah jalan dan kontrol polusi. Pada tepi jalan juga terdapat palem jenis palem raja (Roystonea regia), jenis tersebut lebih ditunjukan untuk nilai estetka pada jalur hijau jalan. Jenis-jenis pohon jalur hijau jalan R3 Kota Bogor dapat dilihat pada Tabel 12 dan untuk sebaran jenis pohon pohon jalur hijau jalan R3 Kota Bogor dapat dilihat pada Gambar 20.

Untuk memperjelas lokasi pohon serta bentukan medan jalan maka jalan R3 Kota Bogor dibagi menjadi 9 segmen jalan. Penentuan segmen jalan hanya untuk memperjelas informasi setiap lokasi pohon, bentukan jalan serta elemen pembentuk di sekitar jalan R3 Kota Bogor. 


\section{Segmen 1}

Pada peta segmen 1 Jalan R3 Kota Bogor yang dapat dilihat di Gambar 20, lokasi jalan berada d awal Jalan R3 dan termasuk ke dalam bagian Jalan Achmad Adnawijaya. Bentuk dimensi jalan dengan lebar jalan $5 \mathrm{~m}$, median jalan berukuran $1 \mathrm{~m}$ dan tepi jalan berukuran $1 \mathrm{~m}$. Pohon-pohon pada segmen 1 di tanam pada bagian median jalan serta pada tepi jalan.

Dari 15 jenis pohon yang dilihat pada segmen 1, terdapat 3 jenis pohon yang sangat dominan, yaitu jenis pohon mahoni (Swietenia mahogani), palem putri (Veitchia merilii) dan palem raja (Roystonea regia). Pohon jenis palem putri (Veitchia merilii) tersebar cukup banyak pada median jalan, sedangkan jenis pohon palem raja (Roystonea regia) tersebar di tepi jalan pada segmen 1, hal itu sangat mendukung karena terdapat banyaknya kawasan perumahan di sekitar jalan pada segmen 1 sehingga menambah nilai estetika.

Selain ketiga jenis pohon tersebut, jenis pohon lainnya di segmen 1 juga tersebar di median dan tepi jalan. Pada median jalan terdapat jenis pohon kenari (Canarium indicum L.), dadap merah (Erythrina cristagalli), beringin (Ficus benjamina), mengkudu (Morinda citrifolia), kamboja bunga merah (Plumeria sp.), jambu klutuk (Psidium guajava), jambu air (Syzygium aqueum) dan tabebuya kuning (Tabebuia rosea). Pada tepi jalan terdapat jenis pohon bintaro (Cerbera manghas) dan bioa cantik (Ficus lyrata). Selain itu juga terdapat jenis pohon yang berada di tepi dan median jalan, yaitu jenis pohon pete cina (Leucaena leucocephala) dan mangga (Mangifera indica). Untuk lebih jelasnya dapat dilihat pada Tabel 15.

Tabel 15 Jenis dan Letak Pohon pada Segmen 1 Jalur Hijau Jalan R3 Kota Bogor

\begin{tabular}{|c|c|c|c|c|c|}
\hline \multirow{2}{*}{ No } & \multirow{2}{*}{ Nama Latin } & \multirow{2}{*}{ Nama Lokal } & \multirow{2}{*}{ Jumlah } & \multicolumn{2}{|c|}{ Lokasi } \\
\hline & & & & Tepi & Median \\
\hline 1 & Canarium indicum L. & Kenari & 2 & & $v$ \\
\hline 2 & Cerbera manghas & Bintaro & 3 & $v$ & \\
\hline 3 & Erythrina cristagalli & Dadap Merah & 3 & & v \\
\hline 4 & Ficus benjamina & Beringin & 1 & & v \\
\hline 5 & Ficus lyrata & Biola Cantik & 3 & v & \\
\hline 6 & Leucaena leucocephala & Pete cina & 5 & $v$ & \\
\hline 7 & Mangifera indica & Mangga & 3 & $\mathrm{v}$ & $\mathrm{v}$ \\
\hline 8 & Morinda citrifolia & Mengkudu & 1 & & v \\
\hline 9 & Plumeria sp. & Kamboja & 1 & & $\mathrm{v}$ \\
\hline 10 & Psidium guajava & Jambu Klutuk & 4 & & v \\
\hline 11 & Roystonea regia & Palem raja & 14 & $\mathrm{v}$ & \\
\hline 12 & Swietenia mahogani & Mahoni & 69 & $\mathrm{v}$ & $\mathrm{v}$ \\
\hline 13 & Syzygium aqueum & Jambu air & 5 & & v \\
\hline 14 & Tabebuia rosea & Tabebuya kuning & 14 & & $\mathrm{v}$ \\
\hline 15 & Veitchia merilii & Palem putri & 58 & & v \\
\hline
\end{tabular}

Sumber : Survey lapang 


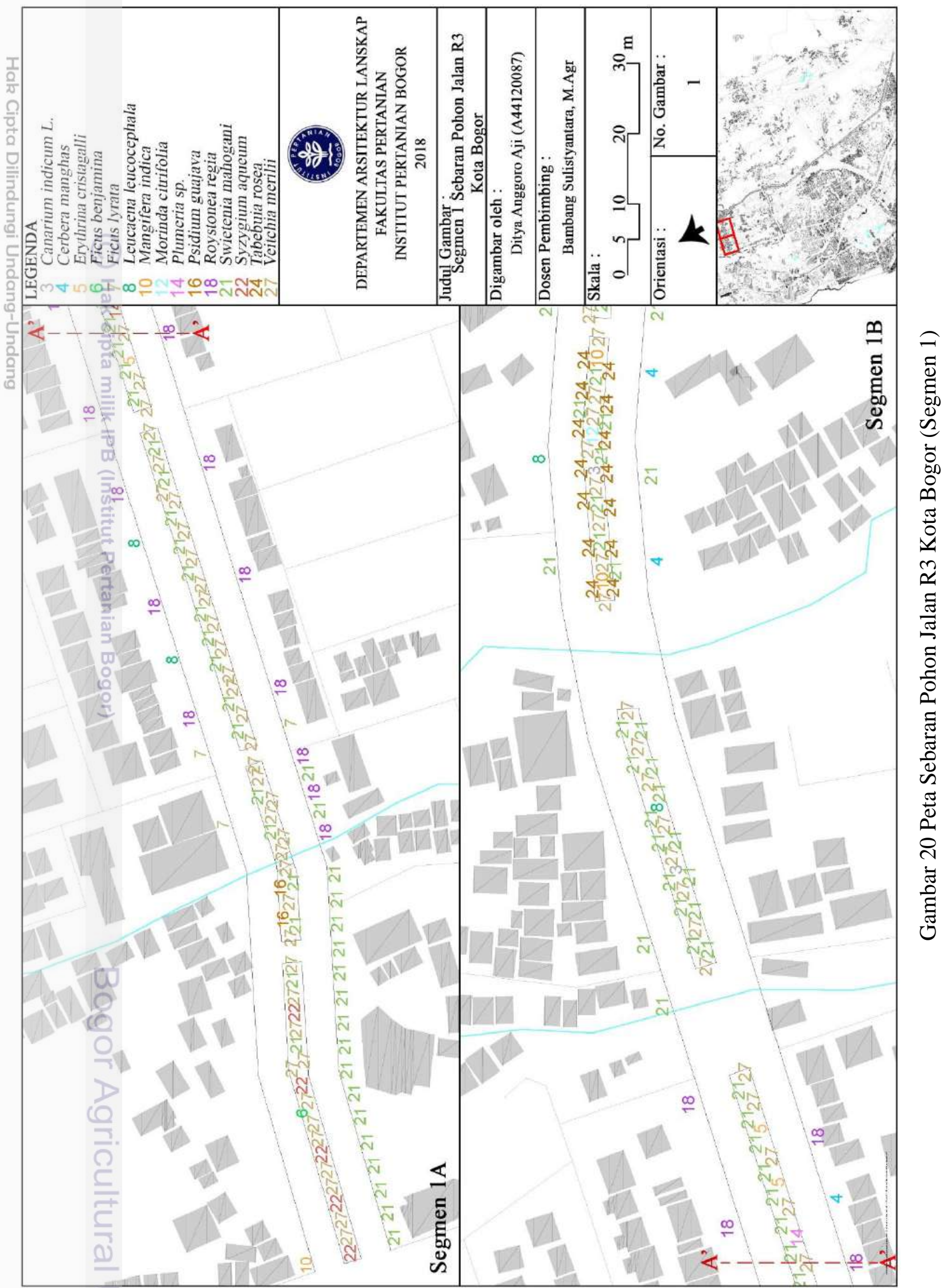




\section{Segmen 2}

Pada peta segmen 2 Jalan R3 Kota Bogor yang dapat dilihat di Gambar 21, lokasi jalan termasuk ke dalam bagian Jalan Achmad Adnawijaya. Bentuk dimensi jalan dengan lebar jalan $5 \mathrm{~m}$, median jalan berukuran $1 \mathrm{~m}$ dan tepi jalan berukuran $1 \mathrm{~m}$. Pohon-pohon pada segmen 2 di tanam pada bagian median jalan serta pada tepi jalan.

Kawasan di sekitar jalan R3 yang ditunjukan pada segmen 2, yaitu kawasankawasan rumah yang tersebar di setiap belokan jalan pada segmen 2. Selain itu terdapat juga bangunan-bangunan yang berada di tepi jalan, bangunan-bangunan tersebut difungsikan sebagai usaha komersil dan pertokoan.

Dari 10 jenis pohon yang dilihat pada segmen 2, terdapat 4 jenis pohon yang sangat dominan, yaitu jenis pohon angsana (Pterocarpus indicus), mahoni (Swietenia mahogani), tabebuya kuning (Tabebuia rosea) dan palem putri (Veitchia merilii). Pohon jenis angsana (Pterocarpus indicus) dan tabebuya kuning (Tabebuia rosea) tersebar cukup banyak pada median jalan, sedangkan jenis pohon mahoni (Swietenia mahogani) dan palem putri (Veitchia merilii) tersebar di medan serta tepi jalan pada segmen 2 .

Selain 4 jenis pohon tersebut, jenis pohon lainnya di segmen 2 juga tersebar di median dan tepi jalan. Pada median jalan terdapat jenis pohon glodogan tiang (Polyathea longifolia) dan jati (Tectona grandis). Pada tepi jalan terdapat jenis pohon bintaro (Cerbera manghas), pinus (Pinus merkusii), palem raja (Roystonea regia) dan pucuk merah (Syzygium oleina). Untuk lebih jelasnya dapat dilihat pada Tabel 16.

Tabel 16 Jenis dan Letak Pohon pada Segmen 2 Jalur Hijau Jalan R3 Kota Bogor

\begin{tabular}{lllccc}
\hline & & & & & \multicolumn{2}{c}{ Lokasi } \\
\cline { 3 - 6 } No Nama Latin & Nama Lokal & Jumlah & Tepi Median \\
\hline 1 & Cerbera manghas & Bintaro & 3 & $\mathrm{v}$ & \\
2 & Pinus merkusii & Pinus & 1 & $\mathrm{v}$ & \\
3 & Polyathea longifolia & Glodogan tiang & 6 & & $\mathrm{v}$ \\
4 & Pterocarpus indicus & Angsana & 44 & & $\mathrm{v}$ \\
5 & Roystonea regia & Palem raja & 2 & $\mathrm{v}$ & \\
6 & Swietenia mahogani & Mahoni & 172 & $\mathrm{v}$ & $\mathrm{v}$ \\
7 & Syzygium oleina & Pucuk Merah & 2 & $\mathrm{v}$ & \\
8 & Tabebuia rosea & Tabebuya kuning & 23 & $\mathrm{v}$ & \\
9 & Tectona grandis & Jati & 4 & & $\mathrm{v}$ \\
10 & Veitchia merilii & Palem putri & 46 & $\mathrm{v}$ & $\mathrm{v}$ \\
\hline \multicolumn{7}{c}{ TOTAL } & & 303 & & \\
\hline
\end{tabular}

Sumber : Survey lapang 


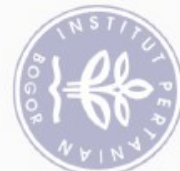
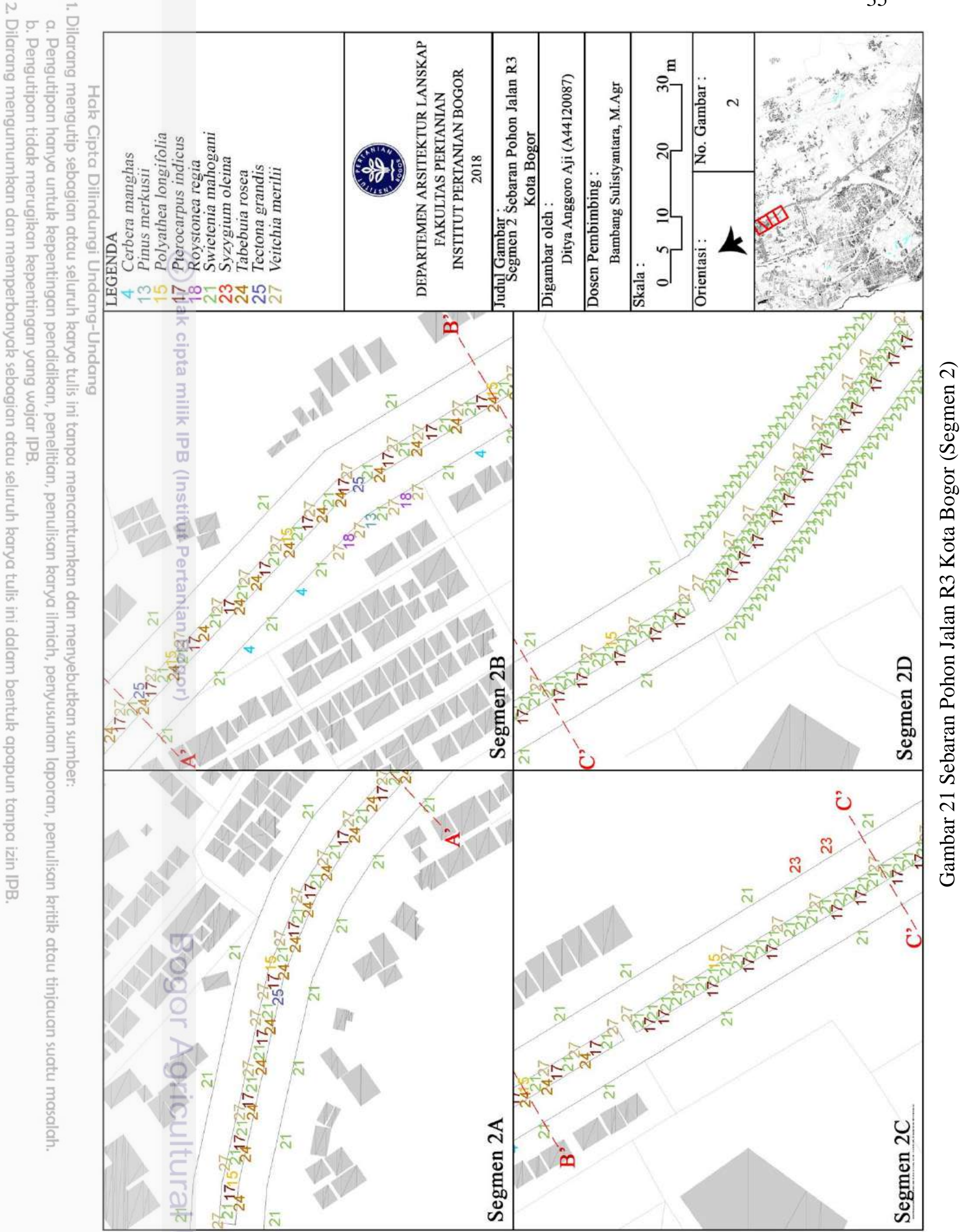


\section{Segmen 3}

Pada peta segmen 3 Jalan R3 Kota Bogor yang dapat dilihat di Gambar 22, lokasi jalan termasuk ke dalam bagian Jalan Achmad Adnawijaya. Bentuk dimensi jalan dengan lebar jalan $5 \mathrm{~m}$, median jalan berukuran $1 \mathrm{~m}$ dan tepi jalan berukuran $1 \mathrm{~m}$. Pohon-pohon pada segmen 3 di tanam pada bagian median jalan serta pada tepi jalan.

Kawasan di sekitar jalan R3 yang ditunjukan pada segmen 3, yaitu kawasankawasan rumah yang tersebar di setiap belokan jalan pada segmen 3. dan juga terdapat bangunan-bangunan yang berada di tepi jalan, bangunan-bangunan tersebut difungsikan sebagai usaha komersil dan pertokoan. Selain itu pada pertigaan besar di segmen 3 terdapat taman corat coret yang berada di sudut jalan.

Dari 9 jenis pohon yang dilihat pada segmen 3, terdapat 2 jenis pohon yang sangat dominan, yaitu jenis pohon bintaro (Cerbera manghas) dan mahoni (Swietenia mahogani). Kedua jenis pohon tersebut tersebar di median dan tepi jalan, jumlah kedua pohon tersebut sangat banyak dibandingkan jumlah jenis pohon lainnya yang terdapat di segmen 3 .

Selain 2 jenis pohon tersebut, jenis pohon lainnya di segmen 3 juga tersebar di median dan tepi jalan. Pada median jalan terdapat jenis pohon cemara norflok (Araucaria heteropylla), nangka (Artocarpus heterophyllus), dadap merah (Erythrina cristagalli), beringin (Ficus benjamina) dan palem putri (Veitchia merilii). Pada tepi jalan terdapat jenis pohon pete cina (Leucaena leucocephala) dan kecrutan (Spathodea campanulata). Untuk lebih jelasnya dapat dilihat pada Tabel 17.

Tabel 17 Jenis dan Letak Pohon pada Segmen 3 Jalur Hijau Jalan R3 Kota Bogor

\begin{tabular}{lllccc}
\hline \multirow{2}{*}{ No Nama Latin } & Nama Lokal & Jumlah & \multicolumn{2}{c}{ Lokasi } \\
\cline { 3 - 6 } & & & Tepi Median \\
\hline 1 & Araucaria heteropylla & Cemara Norfolk & 20 & & $\mathrm{v}$ \\
3 & Artocarpus heterophyllus & Nangka & 1 & $\mathrm{v}$ & \\
4 & Erythrina cristagalli & Dadap Merah & 78 & $\mathrm{v}$ & $\mathrm{v}$ \\
5 & Ficus benjamina & Beringin & 2 & & $\mathrm{v}$ \\
6 & Leucaena leucocephala & Pete cina & 2 & $\mathrm{v}$ & \\
7 & Spathodea campanulata & Kecrutan & 2 & $\mathrm{v}$ & \\
8 & Swietenia mahogani & Mahoni & 171 & $\mathrm{v}$ & $\mathrm{v}$ \\
9 & Veitchia merilii & Palem putri & 1 & & $\mathrm{v}$ \\
\hline \multicolumn{1}{r}{ TOTAL } & & 284 & & \\
\hline
\end{tabular}

Sumber: Survey lapang 


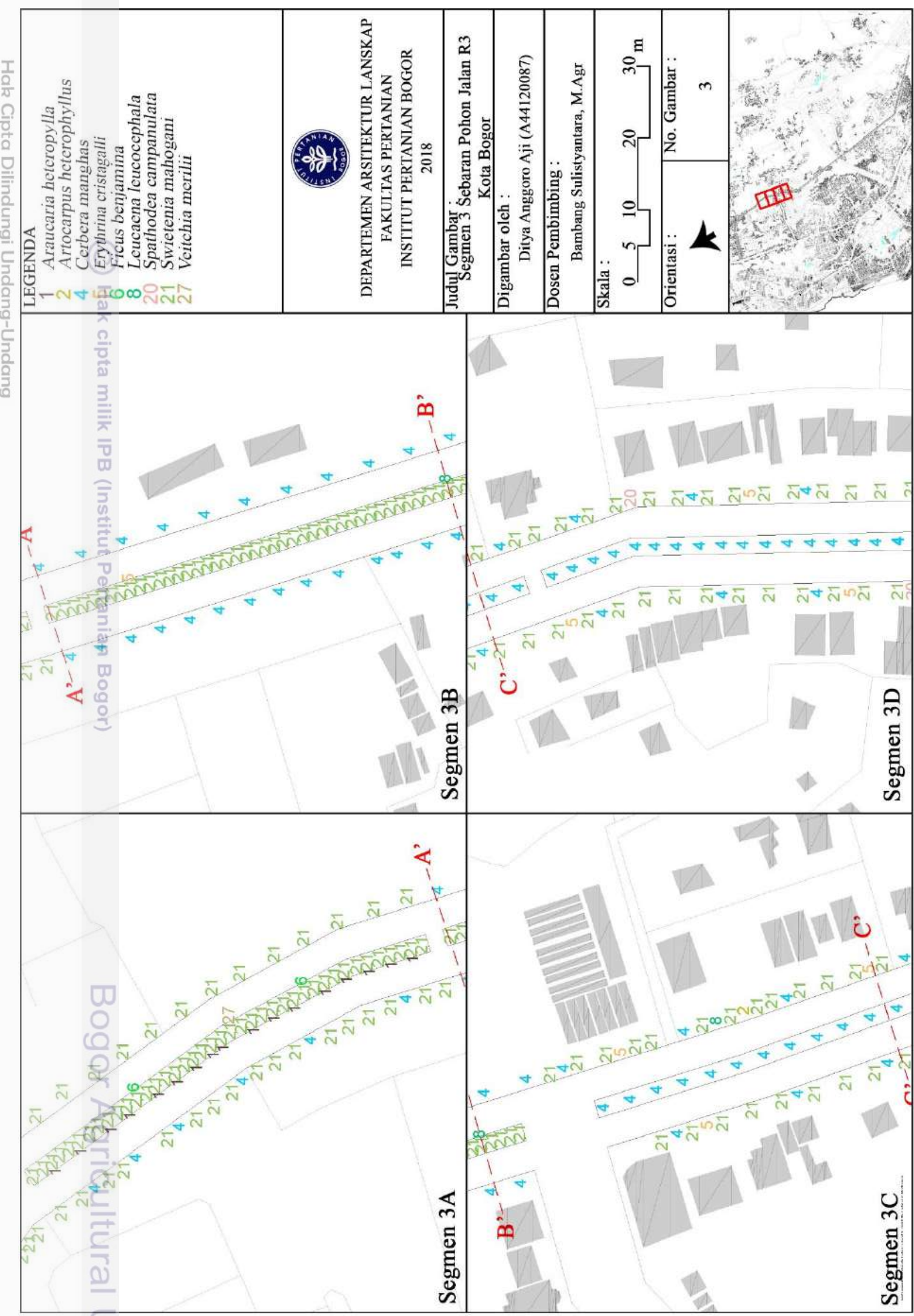




\section{Segmen 4}

Pada peta segmen 4 Jalan R3 Kota Bogor yang dapat dilihat di Gambar 23, lokasi jalan termasuk ke dalam bagian Jalan Achmad Adnawijaya. Bentuk dimensi jalan dengan lebar jalan $5 \mathrm{~m}$, median jalan ada yang berukuran $1 \mathrm{~m}$ dan ada yang berukuran $12 \mathrm{~m}$, serta tepi jalan berukuran $1 \mathrm{~m}$. Pohon-pohon pada segmen $4 \mathrm{di}$ tanam pada bagian median jalan, tepi jalan dan pulau jalan.

Kawasan di sekitar jalan R3 yang ditunjukan pada segmen 4, yaitu kawasankawasan rumah yang tersebar di setiap belokan jalan pada segmen 4. Selain itu terdapat juga bangunan-bangunan yang berada di tepi jalan, bangunan-bangunan tersebut difungsikan sebagai usaha komersil dan pertokoan.

Dari 9 jenis pohon yang dilihat pada segmen 4 , terdapat 4 jenis pohon yang sangat dominan, yaitu jenis pohon bintaro (Cerbera manghas), biola cantik (Ficus lyrata), mangga (Mangifera indica) dan mahoni (Swietenia mahogani). Pohon jenis biola cantik (Ficus lyrata) dan mangga (Mangifera indica) tersebar cukup banyak pada median jalan, sedangkan jenis pohon bintaro (Cerbera manghas) dan mahoni (Swietenia mahogani) tersebar di medan serta tepi jalan pada segmen 4. Terdapat juga pulau jalan yang difungsikan kendaraan untuk memutar di median jalan pada segmen 4, pada median tersebut terdapat jenis pohon mahoni (Swietenia mahogani).

Selain 4 jenis pohon tersebut, jenis pohon lainnya di segmen 4 juga tersebar di median dan tepi jalan. Pada tepi jalan terdapat jenis pohon kenari (Canarium indicum L.), flamboyant (Delonix regia), beringin (Ficus benjamina) dan pete cina (Leucaena leucocephala). Sedangkan jenis pohon kamboja bunga pink (Plumeria rubra) terdapat di median serta tepi jalan pada segmen 4. Untuk lebih jelasnya dapat dilihat pada Tabel 18.

Tabel 18 Jenis dan Letak Pohon pada Segmen 4 Jalur Hijau Jalan R3 Kota Bogor

\begin{tabular}{lllcccc}
\hline \multirow{2}{*}{ No Nama Latin } & Nama Lokal & Jumlah & \multicolumn{2}{c}{ Lokasi } \\
\cline { 5 - 6 } & & & Tepi Median \\
\hline 1 & Canarium indicum L. & Kenari & 9 & $\mathrm{v}$ & \\
2 & Cerbera manghas & Bintaro & 54 & $\mathrm{v}$ & $\mathrm{v}$ \\
3 & Erythrina cristagalli & Dadap Merah & 12 & $\mathrm{v}$ & \\
4 & Ficus benjamina & Beringin & 4 & $\mathrm{v}$ & \\
5 & Ficus lyrata & Biola Cantik & 71 & & $\mathrm{v}$ \\
6 & Leucaena leucocephala & Pete cina & 5 & $\mathrm{v}$ & \\
7 & Mangifera indica & Mangga & 12 & & $\mathrm{v}$ \\
8 & Plumeria sp. & Kamboja & 6 & $\mathrm{v}$ & $\mathrm{v}$ \\
9 & Swietenia mahogani & Mahoni & 128 & $\mathrm{v}$ & $\mathrm{v}$ \\
\hline \multicolumn{1}{c}{ TOTAL } & & 301 & & \\
\hline
\end{tabular}

Sumber: Survey lapang 


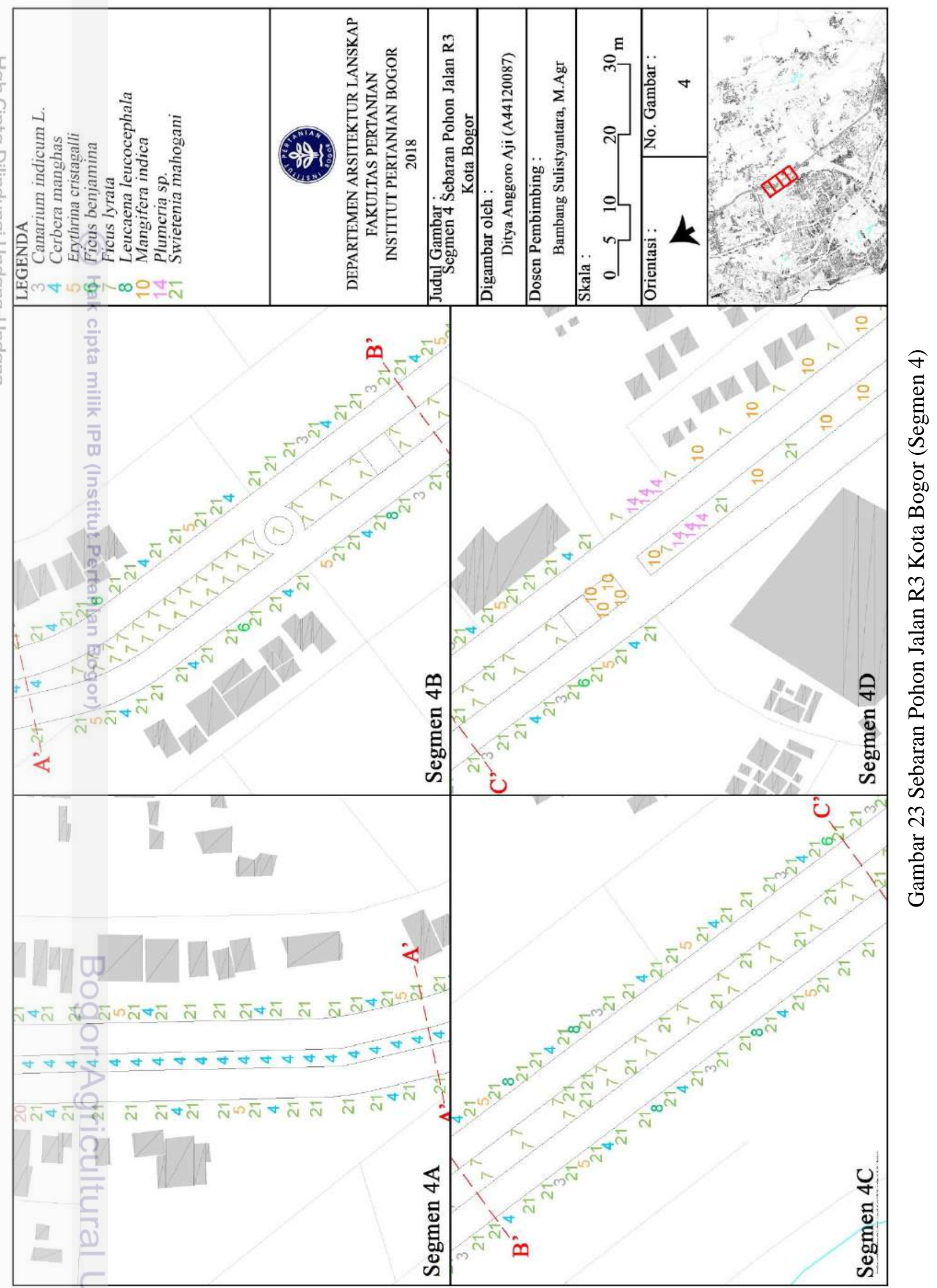




\section{Segmen 5}

Pada peta segmen 5 Jalan R3 Kota Bogor yang dapat dilihat di Gambar 24, lokasi jalan termasuk ke dalam bagian Jalan Kol. Ahmad Syam. Bentuk dimensi jalan dengan lebar jalan $5 \mathrm{~m}$, median jalan ada yang berukuran $1 \mathrm{~m}$ serta tepi jalan berukuran $1 \mathrm{~m}$. Pohon-pohon pada segmen 5 di tanam pada bagian median jalan, tepi jalan dan pulau jalan. Pada akhir segmen 5, lokasi jalan berada di atas Jalan Tol Jagorawi yang berbentuk jembatan.

Kawasan di sekitar jalan R3 yang ditunjukan pada segmen 5, yaitu kawasankawasan rumah yang tersebar di setiap belokan jalan pada segmen 5. Selain itu terdapat juga bangunan-bangunan yang berada di tepi jalan, bangunan-bangunan tersebut difungsikan sebagai usaha komersil dan pertokoan.

Dari 9 jenis pohon yang dilihat pada segmen 5 , terdapat 2 jenis pohon yang sangat dominan, yaitu jenis pohon bintaro (Cerbera manghas) dan mangga (Mangifera indica). Pohon jenis bintaro (Cerbera manghas) tersebar cukup banyak di tepijalan, sedangkan jenis pohon mangga (Mangifera indica) tersebar di medan serta tepi jalan pada segmen 5 .

Selain 2 jenis pohon tersebut, jenis pohon lainnya di segmen 5 juga tersebar di median dan tepi jalan. Pada tepi jalan terdapat jenis pohon tanjung (Mimusops elengi), kecrutan (Spathodea campanulata), mahoni (Swietenia mahogani), pucuk merah (Syzygium oleina) dan palem putri (Veitchia merilii). Sedangkan jenis pohon biola cantik (Ficus lyrata) dan pete cina (Leucaena leucocephala) terdapat di median serta tepi jalan pada segmen 5. Untuk lebih jelasnya dapat dilihat pada Tabel 19.

Tabel 19 Jenis dan Letak Pohon pada Segmen 5 Jalur Hijau Jalan R3 Kota Bogor

\begin{tabular}{lllccc}
\hline \multirow{2}{*}{ No Nama Latin } & Nama Lokal & Jumlah & \multicolumn{2}{c}{ Lokasi } \\
\cline { 5 - 7 } & & Tepi Median \\
\hline 1 & Cerbera manghas & Bintaro & 32 & $\mathrm{v}$ & \\
2 & Ficus lyrata & Biola Cantik & 19 & $\mathrm{v}$ & $\mathrm{v}$ \\
3 & Leucaena leucocephala & Pete cina & 9 & $\mathrm{v}$ & $\mathrm{v}$ \\
4 & Mangifera indica & Mangga & 21 & $\mathrm{v}$ & $\mathrm{v}$ \\
5 & Mimusops elengi & Tanjung & 2 & $\mathrm{v}$ & \\
6 & Spathodea campanulata & Kecrutan & 2 & $\mathrm{v}$ & \\
7 & Swietenia mahogani & Mahoni & 8 & $\mathrm{v}$ & \\
8 & Syzygium oleina & Pucuk Merah & 4 & $\mathrm{v}$ & \\
9 & Veitchia merilii & Palem putri & 3 & $\mathrm{v}$ & \\
\hline \multicolumn{2}{c}{ TOTAL } & & 100 & & \\
\hline
\end{tabular}

Sumber : Survey lapang 


\section{0}
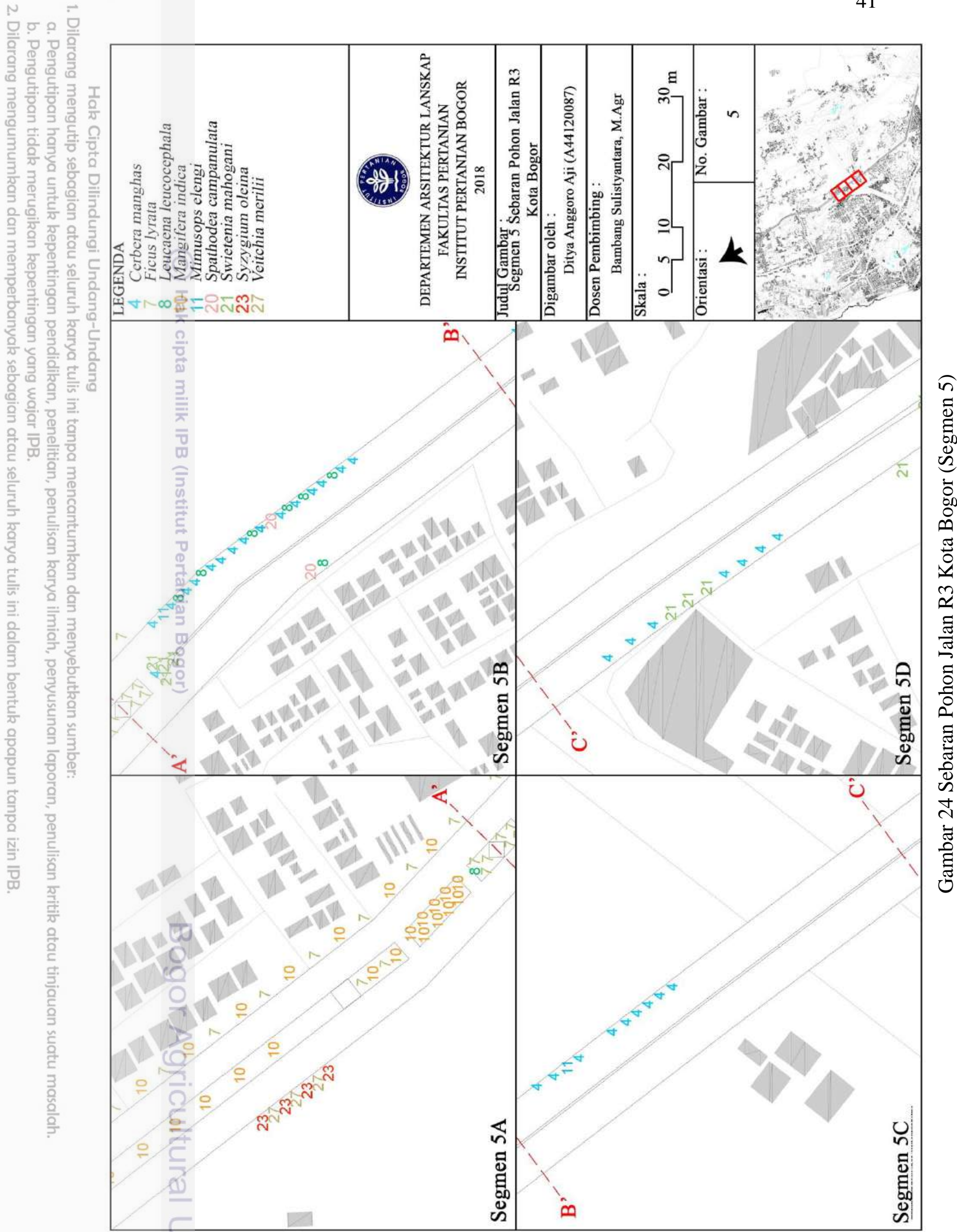


\section{Segmen 6}

Pada peta segmen 6 Jalan R3 Kota Bogor yang dapat dilihat di Gambar 25, lokasi jalan termasuk ke dalam bagian Jalan Kol. Ahmad Syam. Bentuk dimensi jalan dengan lebar jalan $5 \mathrm{~m}$, median jalan ada yang berukuran $12 \mathrm{~m}$ dan ada yang berukuran $3 \mathrm{~m}$, serta tepi jalan berukuran 1m. Pohon-pohon pada segmen 6 di tanam pada bagian median jalan, tepi jalan dan pulau jalan.

Kawasan di sekitar jalan R3 yang ditunjukan pada segmen 6, yaitu kawasankawasan rumah yang tersebar di setiap belokan jalan pada segmen 6. Pada akhir jalan di segmen 6 terdapat usaha komersil berupa penjual tanaman yang berada di tepi jalan di segmen 6 .

Dari 11 jenis pohon yang dilihat pada segmen 6 , terdapat 4 jenis pohon yang sangat dominan, yaitu jenis pohon kamboja (Plumeria sp.), terung bunga ungu (Solanum melongena), mahoni (Swietenia mahogani) dan pucuk merah (Syzygium oleina). Pohon jenis terung bunga ungu (Solanum melongena) tersebar cukup banyak di median jalan, sedangkan jenis pohon mahoni (Swietenia mahogani) dan pucuk merah (Syzygium oleina) tersebar di medan serta tepi jalan pada segmen 6 . Untuk jenis pohon kamboja (Plumeria sp.) yang tersebar juga di median dan tepi jalan terdapat 3 jenis kamboja dengan warna bunga yang berbeda, yaitu kamboja bunga kuning, kamboja bunga merah dan kamboja bunga pink.

Selain 4 jenis pohon tersebut, jenis pohon lainnya di segmen 6 juga tersebar di median dan tepi jalan. Pada median jalan terdapat jenis pohon dadap merah (Erythrina cristagalli). Pada tepi jalan terdapat jenis pohon bintaro (Cerbera manghas), beringin (Ficus benjamina), pete cina (Leucaena leucocephala), mangga (Mangifera indica), tanjung (Mimusops elengi) dan angsana (Pterocarpus indicus). Untuk lebih jelasnya dapat dilihat pada Tabel 20.

Tabel 20 Jenis dan Letak Pohon pada Segmen 6 Jalur Hijau Jalan R3 Kota Bogor

\begin{tabular}{cllccc}
\hline \multirow{2}{*}{ No Nama Latin } & Nama Lokal & Jumlah & \multicolumn{2}{c}{ Lokasi } \\
\cline { 3 - 6 } 1 & Cerbera manghas & Bintaro & 1 & $\mathrm{v}$ & \\
2 & Erythrina cristagalli & Dadap Merah & 12 & & $\mathrm{v}$ \\
3 & Ficus benjamina & Beringin & 16 & $\mathrm{v}$ & \\
4 & Leucaena leucocephala & Pete cina & 3 & $\mathrm{v}$ & \\
5 & Mangifera indica & Mangga & 7 & $\mathrm{v}$ & \\
6 & Mimusops elengi & Tanjung & 6 & $\mathrm{v}$ & \\
7 & Plumeria sp. & Kamboja & 91 & $\mathrm{v}$ & $\mathrm{v}$ \\
8 Pterocarpus indicus & Angsana & 22 & $\mathrm{v}$ & \\
9 & Solanum melongena & Terung bunga ungu & 24 & & $\mathrm{v}$ \\
10 Swietenia mahogani & Mahoni & 176 & $\mathrm{v}$ & $\mathrm{v}$ \\
11 Syzygium oleina & Pucuk Merah & 162 & $\mathrm{v}$ & $\mathrm{v}$ \\
\hline \multicolumn{7}{c}{ TOTAL } & 520 & & \\
\hline
\end{tabular}

Sumber : Survey lapang 


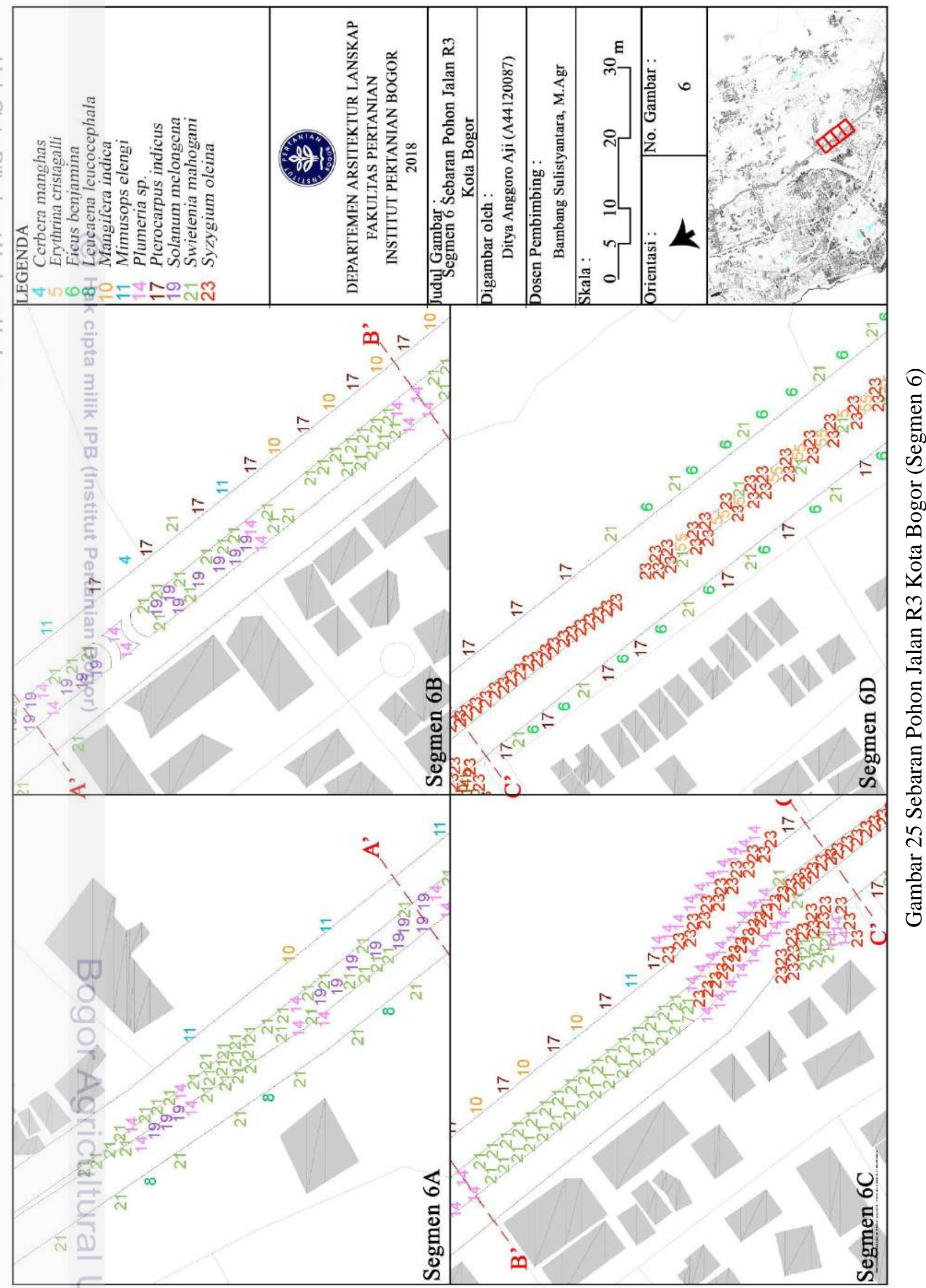




\section{Segmen 7}

Pada peta segmen 6 Jalan R3 Kota Bogor yang dapat dilihat di Gambar 26, lokasi jalan termasuk ke dalam bagian Jalan Kol. Ahmad Syam. Bentuk dimensi jalan dengan lebar jalan $5 \mathrm{~m}$, median jalan yang berukuran $3 \mathrm{~m}$ dan tepi jalan berukuran $1 \mathrm{~m}$. Pohon-pohon pada segmen 7 di tanam pada bagian median jalan, tepi jalan.

Kawasan di sekitar jalan R3 yang ditunjukan pada segmen 7, yaitu kawasankawasan rumah yang tersebar di setiap belokan jalan pada segmen 7 . Terdapat juga usaha komersil berupa penjual tanaman yang berada di sepanjang tepi jalan segmen 7.

Dari 10 jenis pohon yang dilihat pada segmen 7, terdapat 3 jenis pohon yang sangat dominan, yaitu jenis pohon beringin (Ficus benjamina), mahoni (Swietenia mahogani) dan pucuk merah (Syzygium oleina). Pohon jenis pucuk merah (Syzygium oleina) tersebar cukup banyak di median jalan. Pohon jenis beringin (Ficus benjamina) tersebar di tepi jalan. Sedangkan untuk jenis pohon mahoni (Swietenia mahogani) tersebar di median dan tepi jalan pada segmen 7.

Selain 4 jenis pohon tersebut, jenis pohon lainnya di segmen 7 juga tersebar di median dan tepi jalan. Pada median jalan terdapat jenis kenari (Canarium indicum L), palem kipas (Livistona chinensis) dan ketapang kencana (Terminalia mantaly). Pada tepi jalan terdapat jenis pohon dadap merah (Erythrina cristagalli), biola cantik (Ficus lyrata) dan angsana (Pterocarpus indicus). Sedangkan untuk jenis pohon tabebuya kuning (Tabebuia rosea) tersebar di median dan tepi jalan. Untuk $\exists$ ebih jelasnya dapat dilihat pada Tabel 21.

Tabel 21 Jenis dan Letak Pohon pada Segmen 7 Jalur Hijau Jalan R3 Kota Bogor

\begin{tabular}{cllccc}
\hline \multirow{2}{*}{ No Nama Latin } & Nama Lokal & Jumlah & \multicolumn{2}{c}{ Lokasi } \\
\hline 1 & Canarium indicum L. & Kenari & 1 & & Tepi Median \\
2 & Erythrina cristagalli & Dadap Merah & 15 & $\mathrm{v}$ & \\
3 & Ficus benjamina & Beringin & 48 & $\mathrm{v}$ & \\
4 & Ficus lyrata & Biola Cantik & 3 & $\mathrm{v}$ & \\
5 & Livistona chinensis & Palem kipas & 5 & & $\mathrm{v}$ \\
6 & Pterocarpus indicus & Angsana & 6 & $\mathrm{v}$ & \\
7 & Swietenia mahogani & Mahoni & 64 & $\mathrm{v}$ & $\mathrm{v}$ \\
8 & Syzygium oleina & Pucuk Merah & 275 & & $\mathrm{v}$ \\
9 & Tabebuia rosea & Tabebuya kuning & 7 & $\mathrm{v}$ & $\mathrm{v}$ \\
10 Terminalia mantaly & Ketapang kencana & 9 & & $\mathrm{v}$ \\
\hline \multicolumn{2}{c}{ TOTAL } & 433 & &
\end{tabular}

Sumber : Survey lapang 


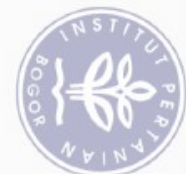
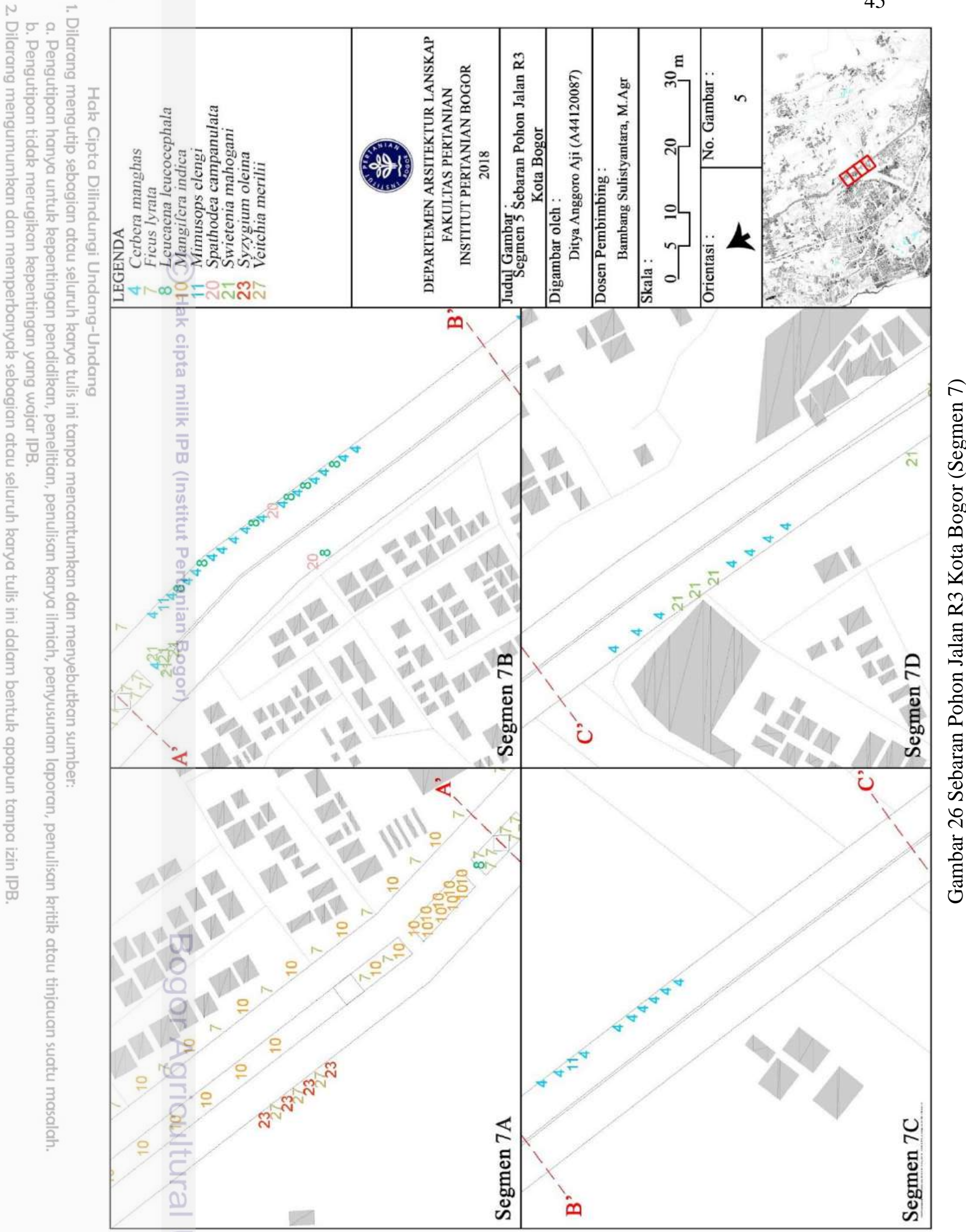


\section{Segmen 8 dan 9}

Pada peta segmen 8 dan 9 Jalan R3 Kota Bogor yang dapat dilihat di Gambar 27 dan Gambar 28, lokasi jalan termasuk ke dalam bagian Jalan Kol. Ahmad Syam. Dimensi jalan dengan lebar jalan $5 \mathrm{~m}$, median jalan $3 \mathrm{~m}$ dan tepi jalan $1 \mathrm{~m}$. Pohon pada kedua segmen tersebut di tanam pada bagian median jalan, tepi jalan.

Pada segmen 8, dari 6 jenis pohon terdapat 3 jenis pohon yang sangat dominan, yaitu jenis pohon palem kipas (Livistona chinensis), mahoni (Swietenia mahogani) dan pucuk merah (Syzygium oleina). Pohon jenis palem kipas (Livistona chinensis) dan pucuk merah (Syzygium oleina) tersebar cukup banyak di median jalan. Sedangkan untuk jenis pohon mahoni (Swietenia mahogani) tersebar tepi jalan pada segmen 8 . Selain jenis pohon tersebut, jenis pohon lainnya di segmen 8 tersebar di tepi jalan. Pohon tersebut yaitu jenis pohon beringin (Ficus benjamina), tabebuya kuning (Tabebuia rosea) dan ketapang kencana (Terminalia mantaly). Untuk lebih jelasnya dapat dilihat pada Tabel 22.

Tabel 22 Jenis dan Letak Pohon pada Segmen 8 Jalur Hijau Jalan R3 Kota Bogor

\begin{tabular}{lllccc}
\hline \multirow{2}{*}{ No Nama Latin } & \multirow{2}{*}{ Nama Lokal } & Jumlah & \multicolumn{2}{c}{ Lokasi } \\
\hline 6 & Ficus benjamina & Beringin & 11 & $\mathrm{v}$ & \\
9 & Livistona chinensis & Palem kipas & 46 & & $\mathrm{v}$ \\
21 & Swietenia mahogani & Mahoni & 51 & $\mathrm{v}$ & $\mathrm{v}$ \\
23 & Syzygium oleina & Pucuk Merah & 222 & & $\mathrm{v}$ \\
24 & Tabebuia rosea & Tabebuya kuning & 1 & $\mathrm{v}$ & \\
26 & Terminalia mantaly & Ketapang kencana & 2 & $\mathrm{v}$ & \\
\hline \multicolumn{2}{c}{ TOTAL } & 333 & & \\
\hline
\end{tabular}

Sumber : Survey lapang

Pada segmen 9, dari 4 jenis pohon terdapat 3 jenis pohon yang sangat dominan, yaitu jenis pohon palem kipas (Livistona chinensis), mahoni (Swietenia mahogani) dan pucuk merah (Syzygium oleina). Pohon jenis palem kipas (Livistona chinensis) dan pucuk merah (Syzygium oleina) tersebar cukup banyak di median jalan. Sedangkan untuk jenis pohon mahoni (Swietenia mahogani) tersebar tepi jalan pada segmen 9. Selain ketiga jenis pohon tersebut, jenis pohon beringin (Ficus benjamina) tersebar di tepi jalan pada segmen 9. Untuk lebih jelasnya dapat dilihat pada Tabel 23.

Tabel Jenis dan Letak Pohon pada Segmen 9 Jalur Hijau Jalan R3 Kota Bogor

\begin{tabular}{|c|c|c|c|c|c|}
\hline \multirow{2}{*}{ No } & \multirow{2}{*}{ Nama Latin } & \multirow{2}{*}{ Nama Lokal } & \multirow{2}{*}{ Jumlah } & \multicolumn{2}{|c|}{ Lokasi } \\
\hline & & & & Tepi & Median \\
\hline 6 & Ficus benjamina & Beringin & 5 & $\mathrm{v}$ & \\
\hline 9 & Livistona chinensis & Palem kipas & 21 & & $\mathrm{v}$ \\
\hline 21 & Swietenia mahogani & Mahoni & 90 & $\mathrm{v}$ & \\
\hline 23 & Syzygium oleina & Pucuk Merah & 162 & & $\mathrm{v}$ \\
\hline & $\mathrm{TC}$ & & 278 & & \\
\hline
\end{tabular}

Sumber: Survey lapang 


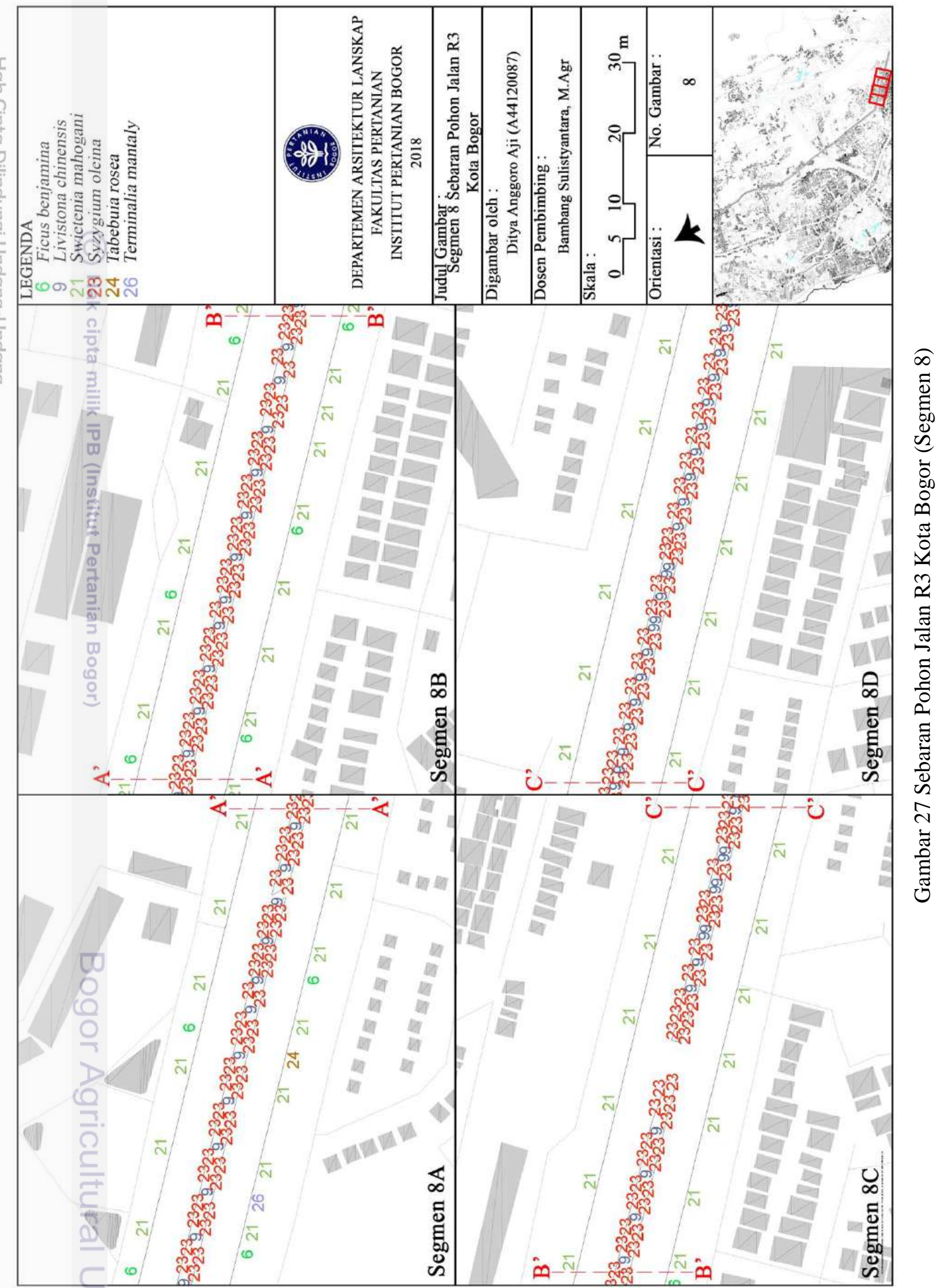




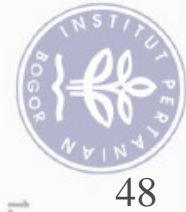

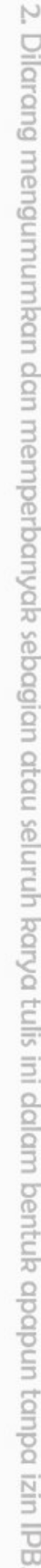
$\sigma \circ$

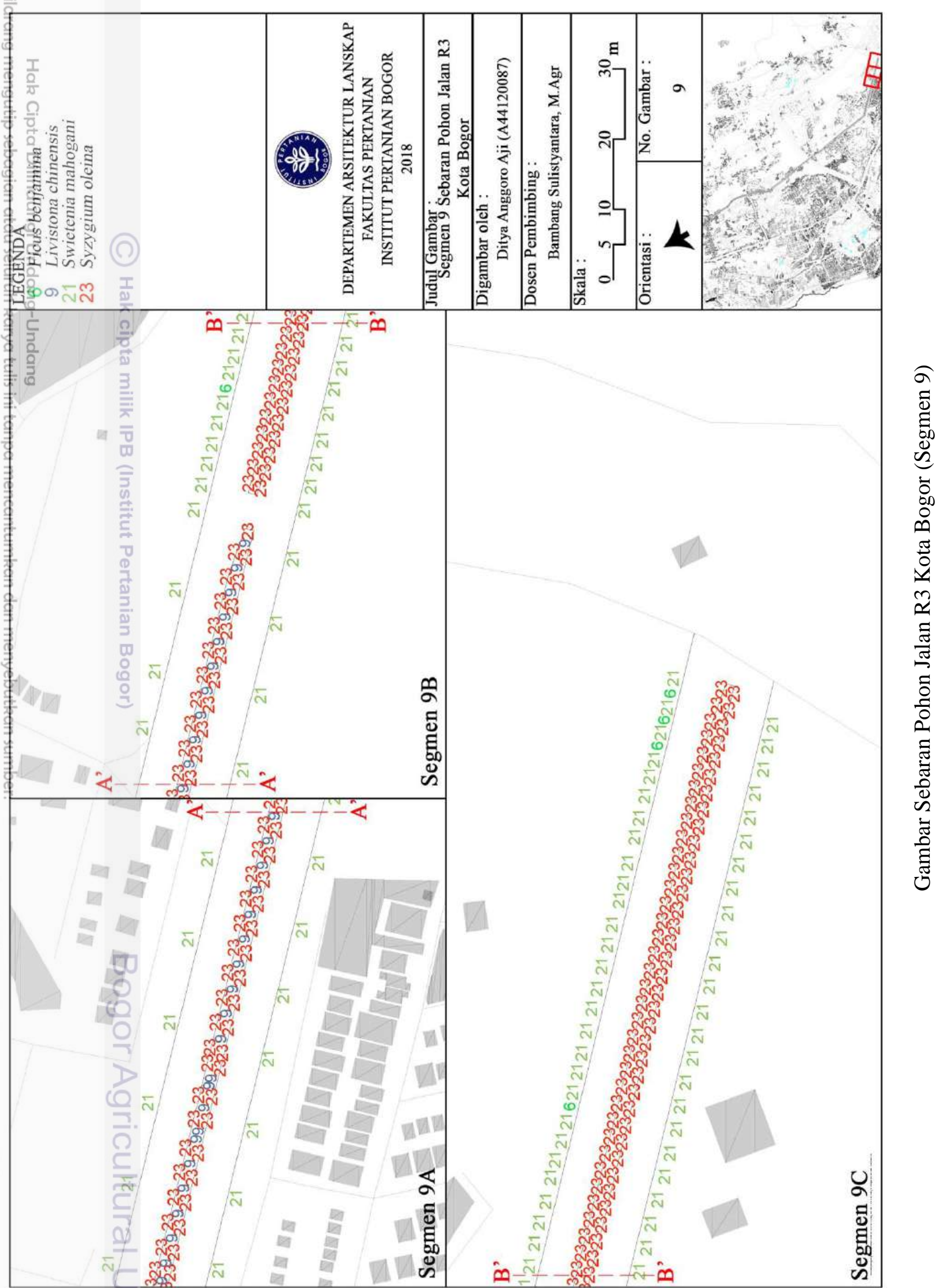




\section{Fungsi Ekologis Pohon Sebagai Penyerap Polutan}

Pohon diketahui efektif dalam menyerap karbon dioksida (CO2) dan menghasilkan oksigen $\left(\mathrm{O}_{2}\right)$. Beberapa jenis pohon pada jalur hijau jalan R3 Kota Bogor diketahui memiliki tingkat serapan karbon dioksida. Pohon-pohon tersebut yaitu beringin (Ficus benjamina), mahoni (Swietenia mahagoni), jati (Tectona grandis), tanjung (Mimusoph elengi), angsana (Pterocarpus indicus) dan dadap merah (Erythrina cristagalli). Besar serapan jenis-jenis pohon tersebut bervariasi. Perbedaan besar serapan untuk tiap jenis pohon menandakan kemampuan menyerap karbon dioksida. Angka-angka serapan CO2 beberapa jenis pohon di jalan R3 Kota Bogor dapat dilihat pada Tabel 24.

Tabel 24 Tingkat Serapan Karbon Dioksida (CO2) Beberapa Pohon di Jalan R3 Kota Bogor

\begin{tabular}{lllc}
\hline$\overline{\mathrm{N}}$ o & Nama Latin & Nama Lokal & Daya serap CO2 (kg/pohon/hari) \\
\hline 1 & Ficus benjamina & Beringin & 1,468 \\
2 & Swietenia mahoganii & Mahoni & 0,810 \\
3 & Tectona grandis & Jati & 0,371 \\
4 & Mimusoph elengi & Tanjung & 0,094 \\
5 & Pterocarpus indicus & Angsana & 0,030 \\
6 & Erythrina cristagalli & Dadap merah & 0,012 \\
\hline
\end{tabular}

Sumber : Duryatmo dan Sardi (2008)

Kemampuan ruang terbuka hijau dalam membersihkan pencemaran udara juga dipengaruhi oleh kepadatan dan struktur vegetasi. Ruang terbuka hijau dengan beberapa lapisan tanaman seperti, semak, perdu, dan pohon, dapat mereduksi lebih efektif. Jalur hijau jalan R3 Kota Bogor memiliki penanaman yang berlapis. Selain penanaman pohon, ruang terbuka hijau juga ditanami berbagai jenis perdu, semak, groundcover dan rumput. Struktur jalur hijau jalan R3 Kota Bogor ini memiliki potensi dalam membersihkan pencemaran udara.

\section{Analisis Emisi CO2 Jalur Hijau Jalan}

Jalan merupakan sarana pada sistem transportasi dan dilalui oleh berbagai macam jenis alat transportasi. Kawasan perkotaan umumnya memiliki lalu lintas yang padat sehingga tingkat polusi kota lebih tinggi dibandingkan kawasan sekitarnya.

\section{Jumlah Kendaraan}

Jumlah kendaraan di Jalan R3 Kota Bogor dihitung dengan bantuan applikasi traffic count pada HP. Metode perhitungan dilakukan di 9 titik yang sudah ditentukan di sepanjang jalan. Perhitungan dilakukan selama 4 kali selama 1 jam di hari yang sama. Waktu perhitungan dilakukan pada jam 08:00, 12:00, 16:00, dan 20:00. Hal itu dilakukan agar mendapatkan data yang akurat. Hari perhitungan dilakukan pada waktu weekend, yaitu hari sabtu tanggal 26 Mei 2018. Jumlah maks dan min per jam dapat dilihat pada Tabel 25. 
Tabel 25 Jumlah Maks dan Min Kendaraan per Jam di Jalan R3 Kota Bogor

\begin{tabular}{ccccccc}
\hline \multirow{2}{*}{ Titik Pengambilan } & \multirow{2}{*}{ Motor } & $\begin{array}{c}\text { Mobil } \\
\text { Bensin }\end{array}$ & $\begin{array}{c}\text { Mobil } \\
\text { Diesel }\end{array}$ & $\begin{array}{c}\text { Truk } \\
\text { Kecil }\end{array}$ & $\begin{array}{c}\text { Truk } \\
\text { Sedang }\end{array}$ & \multirow{2}{*}{ Taksi } \\
\hline Segmen 1 & $2320-4590$ & $692-1094$ & $42-66$ & $6-42$ & $4-16$ & - \\
Segmen 2 & $2948-4843$ & $782-1528$ & $38-67$ & $27-42$ & $5-11$ & - \\
Segmen 3 & $3405-6956$ & $980-1525$ & $43-69$ & $9-78$ & $2-50$ & - \\
Segmen 4 & $4327-7676$ & $954-1927$ & $93-253$ & $19-201$ & $5-81$ & $1-2$ \\
Segmen 5 & $3163-5142$ & $1269-2945$ & $16-53$ & $1-49$ & $2-23$ & $1-3$ \\
Segmen 6 & $748-4391$ & $281-1525$ & $18-42$ & $5-40$ & $1-5$ & $1-3$ \\
Segmen 7 & $1640-6153$ & $430-1214$ & $28-75$ & $3-49$ & $2-14$ & 1 \\
Segmen 8 & $1298-2967$ & $372-741$ & $5-21$ & $4-52$ & $1-15$ & 2 \\
Segmen 9 & $737-2872$ & $206-468$ & $3-7$ & $7-17$ & $3-20$ & 2 \\
\hline
\end{tabular}

Sumber: Survei Lapang

Jika dilihat dari Tabel 25, segmen 3, segmen 4 dan segmen 5 memiliki ratarata jumlah kendaraan yang paling banyak dibandingkan dengan segmen lainnya, karena ketiga segmen tersebut merupakan jalan dengan kondisi aktifitas kendaraan yang tinggi. Sedangkan segmen 9 memiliki rata-rata jumlah kendaraan yang paling sedikit, karena wilayah di sekitar segmen 9 merupakan area perumahan.

\section{Emisi CO2}

Menurut Adiastari (2010) emisi CO2 dapat dihitung menggunakan perhitungan matematis sederhana dengan bantuan data dari jumlah kendaraan. Rumus perhitungan dapat dilihat di bagian metode penelitian pada halaman 12 . Jumlah emisi CO2 di Jalan R3 Kota Bogor dapat dilihat di Gambar 29.

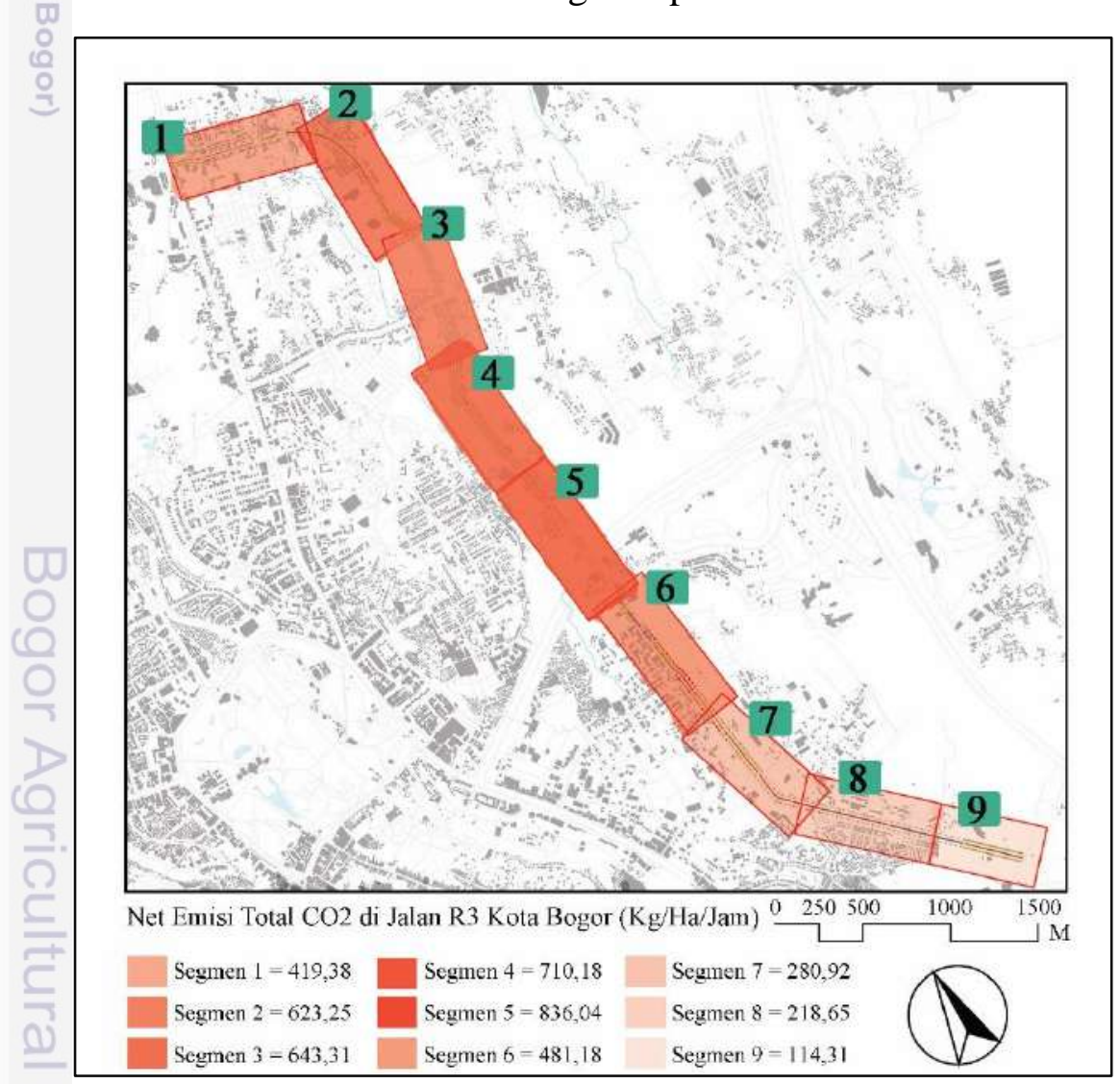

Gambar 29 Peta Emisi CO2 di Jalan R3 Kota Bogor 
Hasil perhitungan emisi $\mathrm{CO} 2$ berbanding lurus dengan data jumlah kendaraan. Jika dilihat pada Gambar 29, Segmen 5 merupakan area di sepanjang Jalan R3 dengan emisi CO2 terbanyak yaitu 836,04 kg/ha/jam. Besarnya emisi CO2 pada segmen tersebut sesuai dengan data pada Tabel 24 , dimana segmen dengan rata-rata jumlah kendaraan terbanyak memilki jumlah emisi $\mathrm{CO} 2$ yang tinggi. Sedangkan segmen 7, segmen 8 dan segmen 9 memiliki jumlah emisi CO2 yang rendah karena memiliki rata-rata jumlah kendaraan yang lebih sedikit.

\section{Vegetasi Sebagai Penyerap CO2}

Vegetasi pada umumnya memiliki kemampuan untuk menyerap CO2. Emisi karbon total merupakan penjumlahan dari nilai emisi karbon tiap jenis kendaraan di sepanjang Jalan R3 Kota Bogor. Dengan melakukan pendekatan matematis, secara sederhana debit emisi dapat direduksi oleh RTH berupa penutupan tajuk pohon di sepanjang jalan R3 Kota Bogor. Jumlah serapan CO2 pada Jalan R3 dapat dilihat pada Gambar 30 dan luas tutupan vegetasi per segmen dapat dilihat di Tabel 26.

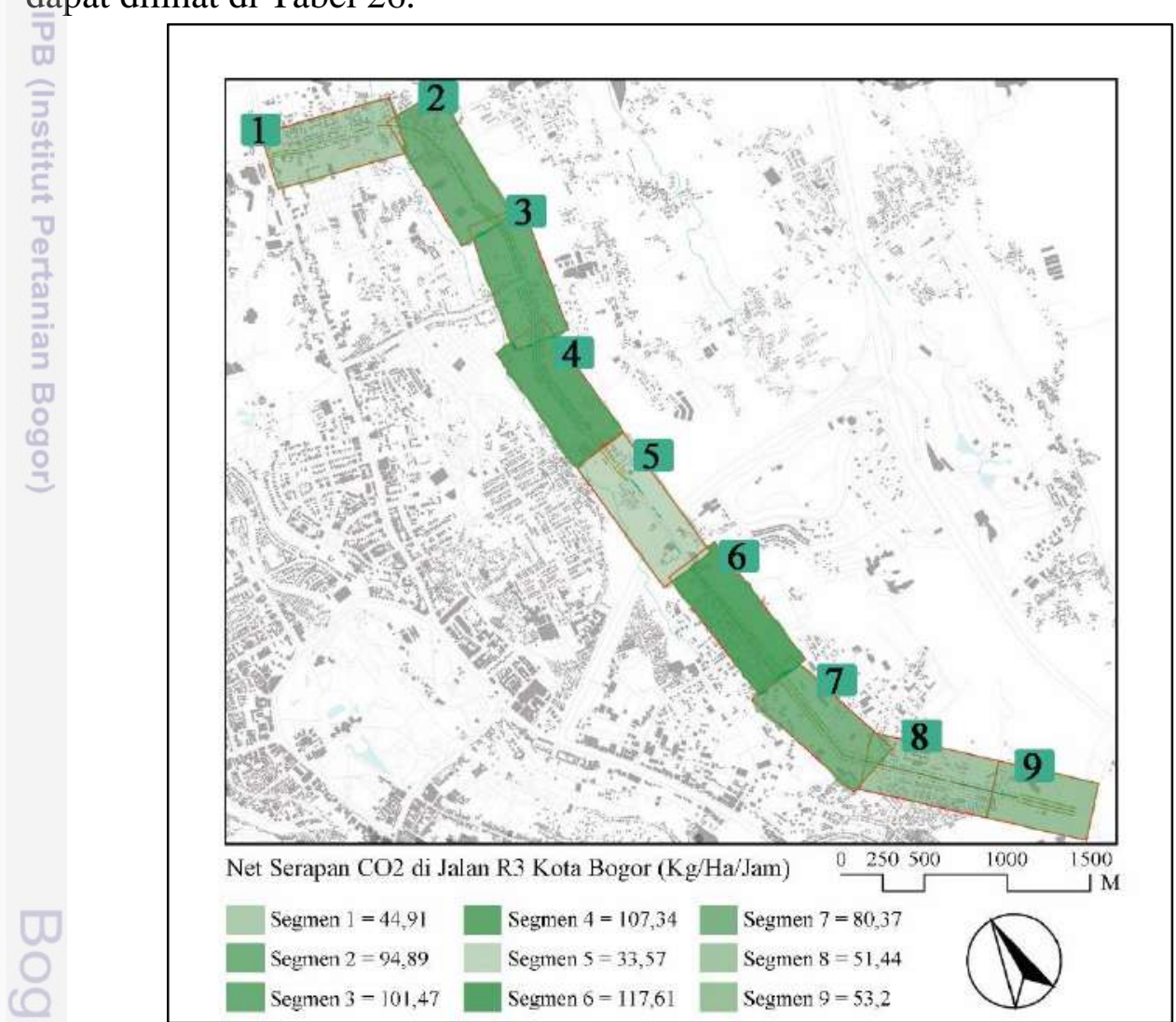

Gambar 30 Peta Serapan CO2 di Jalan R3 Kota Bogor

Tabel 26 Luas Tutupan Vegetasi per Segmen

\begin{tabular}{ccc}
\hline Titik Segmen & Luas tutupan vegetasi (ha) & Serapan CO2 $(\mathrm{kg} / \mathrm{ha} / \mathrm{jam})$ \\
\hline Segmen 1 & 0,346 & 44,91 \\
Segmen 2 & 0,730 & 94,84 \\
Segmen 3 & 0,781 & 101,47 \\
Segmen 4 & 0,826 & 107,34 \\
Segmen 5 & 0,258 & 33,57 \\
\hline
\end{tabular}


Tabel 26 Luas Tutupan Vegetasi per Segmen (Lanjutan)

\begin{tabular}{ccc}
\hline Titik Segmen & Luas tutupan vegetasi (ha) & Serapan CO2 (Kg/ha/jam) \\
\hline Segmen 6 & 0,905 & 117,61 \\
Segmen 7 & 0,619 & 80,37 \\
Segmen 9 & 0,396 & 51,44 \\
Segmen 10 & 0,410 & 53,20 \\
\hline
\end{tabular}

Sumber : Survei Lapang

Segmen dengan jumlah tutupan vegetasi yang luas tentunya memiliki jumlah vegetasi yang banyak. Selain jumlah vegetasi yang tertanam, faktor luasan naungan vegetasi yang lebar juga mempengaruhi kemampuan serapan CO2. Segmen 6 memiliki jumlah serapan CO2 yang paling tinggi yaitu 117,61 kg/ha/jam, hal itu terbukti dengan banyaknya jumlah vegetasi yang tertanam serta memiliki naungan pohon yang lebar.

\section{Sisa Emisi CO2 di Jalan R3 Kota Bogor}

Emisi total merupakan penjumlahan dari nilai emisi karbon tiap jenis kendaraan di sepanjang Jalan R3 Kota Bogor. Dengan melakukan pendekatan matematis, secara sederhana debit emisi dapat direduksi oleh RTH berupa penutupan tajuk pohon di sepanjang jalan R3 Kota Bogor. Dari hasil analisis spasial tersebut dapat dihasilkan peta daya serap $\mathrm{CO} 2$ dan peta hasil emisi $\mathrm{CO} 2$, yang kemudian dua peta tersebut di overlay sehingga mendapatkan titik segmen terbaik pada jalan R3 Kota Bogor. Segmen terbaik tersebut akan dijadikan rekomendasi jalur hijau jalan. Sisa emisi CO2 dapat dilihat pada Gambar 31.

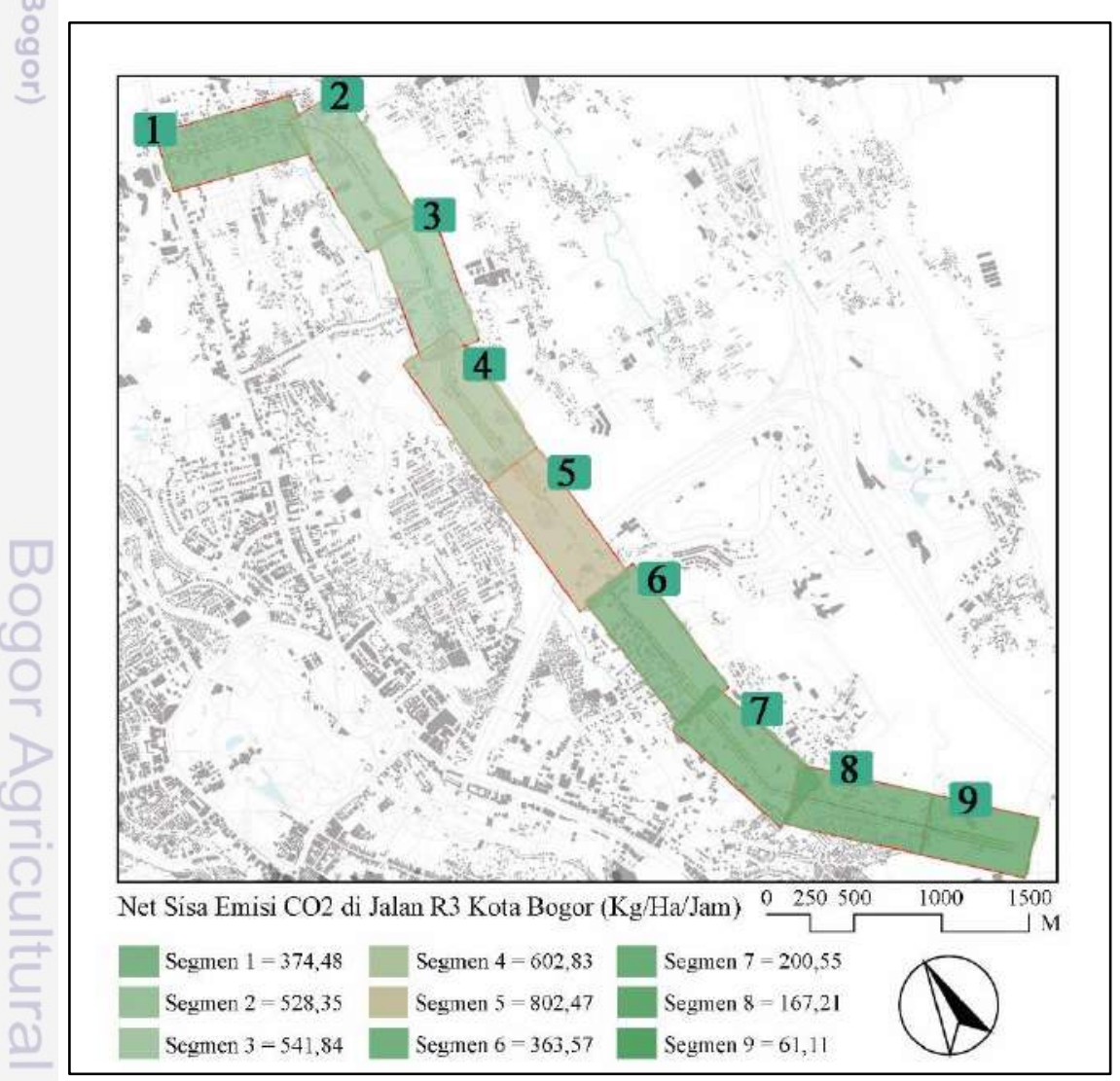

Gambar 31 Peta Sisa Emisi CO2 di Jalan R3 Kota Bogor 
Hasil peta sisa emisi CO2 pada Gambar 31 nilai yang berbeda-beda. Total emisi CO2 di sepanjang jalan adalah 4327,206 kg/ha/jam, sedangkan total daya serap CO2 di sepanjang jalan adalah $684,793 \mathrm{~kg} / \mathrm{ha} / \mathrm{jam}$. Sehingga hasil perhitungan sisa emisi CO2 pada Jalan R3 Kota Bogor adalah 3642,413 kg/ha/jam. Hasil sisa emisi $\mathrm{CO} 2$ menunjukkan bahwa vegetasi yang tertanam pada jalan belum cukup untuk mereduksi emisi $\mathrm{CO} 2$ yang dihasilkan oleh kendaraan. Sehingga membutuhkan penanaman pohon dengan kemampuan serapan $\mathrm{CO} 2$ yang tinggi.

\section{Evaluasi Vegetasi Sebagai Penyerap Polutan Gas}

Pohon mereduksi polusi melalui penyerapan gas pencemar. Penilaian vegetasi jalur hijau jalan untuk fungsi penyerap polutan gas dilakukan pada pohon tepi jalan, median, dan pulau jalan (traffic islands). Penilaian dilakukan dengan membandingkan kondisi pohon pada lokasi penelitian dengan kriteria-kriteria $\overline{\bar{v}}$ getasi yang efektif dalam mereduksi polusi yang di dapat dari litelatur yang terkait.

Untuk menyerap polusi dengan baik, diperlukan luas permukaan vegetasi yang cukup tinggi. Vegetasi-vegetasi dengan ketinggian yang bervariasi dapat menghalangi menyebarnya polutan. Kombinasi pohon dengan perdu, semak, dan groundcover dapat menghalamgi dan memperlambat penyebaran polutan. Penanaman beberapa lapis pohon akan lebih efektif dalam mereduksi polusi.

Daun berperan penting dalam menyerap polutan udara. Jumlah daun pada suatu pohon dapt mempengaruhi penyerapan zat pencemar, sehingga dengan jumlah daun yang banyak maka akan lebih baik dalam penyerapan zat pencemar dan dapat mereduksi polusi dengan lebih baik. Ketebalan daun juga mempengaruhi kemampuan suatu pohon untuk menyerap gas. Duan yang tipis akan lebih mudah menyerap gas dan lebih baik mereduksi zat pencemar udara.

Kepadatan tajuk pohon mempengaruhi kefektifan penyaringan zat pencemar udara. Tajuk yang rapat dan padat dapat menyerap polusi lebih baik dibanding dengan tajuk yang terbuka. Jarak tanam yang rapat akan berfungsi lebih baik untuk mereduksi polusi serta akan menjadi penghalang untuk penyebaran zat pencemar. Dari hasil penelitian, dapat diketahui jenis-jenis tanaman pada jalur hijau jalan R3 Kota Bogor yang sangat sesuai, sesuai, kurang sesuai dan tidak sesuai untk fungsi menyerap polutan gas.

Jenis pohon yang sangat sesuai untuk menyerap polutan gas dari hasil penilaian evaluasi yaitu, mahoni (Swietenia mahagoni), pucuk merah (Syzygium oleina), bintaro (Cerbera manghas), biola cantik (Ficus lyrata), angsana (Pterocarpus indicus), dadap (Erythrina cristagalli), terung bunga ungu (Solanum melongena), tabebuya kuning (Tabebuia rosea), mangga (Mangifera indica), ketapang kencana (Terminalia mantaly), kenari (Canarium indicum L.). Pohon jenis mahoni (Swietenia mahagoni), pucuk merah (Syzygium oleina), bintaro (Cerbera manghas), biola cantik (Ficus lyrata), angsana (Pterocarpus indicus) merupakan jenis tanaman utama pada jalur hijau jalan ini dan ditanam dalam jumlah banyak pada median serta tepi dengan beberapa lapis tanaman. Selain itu, kelima jenis ini juga memiliki karakter fisik yang menunjang untuk menyerap polutan gas seperti tajuk yang rapat dan padat, memiliki jumlah daun yang banyak, rata-rata jenis pohon memiliki daun yang tipis lunak, dan ditanam dalam jarak yang rapat. 
Selain itu, penanaman juga dikombinasikan dengan perdu, semak, dan groundcover.

Pohon yang sesuai untuk fungsi penyerap polutan gas yaitu, cemara norfolk (Araucaria heteropylla), nangka (Artocarpus heterophyllus), beringin (Ficus benjaminal), pete cina (Leucaena leucocephala), tanjung (Mimusops elengi), mengkudu (Morinda citrifolia), pinus (Pinus merkusii), glodogan tiang (Polyathea longifolia), jambu klutuk (Psidium guajava), kecrutan (Spathodea campanulata), palem putri (Veitchia merilii). Jenis-jenis pohon ini umumnya memiliki tajuk yang sedang padat hingga padat, jumlah daun yang cukup banyak, memiliki jenis daun yang tipis perkamen (palem kipas) hingga tipis lunak (palem putri), jarak antar pohon diatanam cukup rapat, dan penanaman dikombinasikan dengan perdu, semak, dan groundcover. Namun, beberapa jenis pohon hanya ditanaman dengan kombinasi pohon dan perdu contohnya glodogan tiang (Polyathea longifolia), cemara norfolk (Araucaria heteropylla), dan tanjung (Mimusops elengi).

Pohon yang tidak sesuai sesuai untuk fungsi penyerap polutan gas yaitu, kamboja (Plumeria sp.), palem raja (Roystonea regia), dan jati (Tectona grandis). Ketigajenis pohon ini di klasifikasian sebagai tanaman yang kurang sesuai karena memiliki kepadatan tajuk yang sedikit, beberapa jenis pohon ditanam berjauhaan, dan memiliki jumlah daun yang sedikit hingga cukup. Namun ketiga jenis ini memiliki jenis daun yang tipis lunak, penanaman dengan kombinasi perdu dan semak, dan salah satu jenis pohon yaitu kamboja (Plumeria sp.) memiliki jarak tanam yang rapat. Jenis kamboja (Plumeria sp.) memiliki jumlah yang banyak di beberapa median serta tepi jalan R3 Kota Bogor.

Berdasarkan hasil evaluasi jenis-jenis pohon di Jalan R3 Kota Bogor tidak ada yañg masuk kedalam klasifikasi tidak sesuai sebagai fungsi penyerap polutan gas. Untuk nilai-nilai evaluasi kriteria sebagai penyerap polutan gas setiap jenis pohon dapat dilihat pada Tabel 27 dan Gambar 32.

Tabel 27 Evaluasi Fungsi Tanaman Menyerap Polutan Gas

\begin{tabular}{|c|c|c|c|c|c|c|c|c|c|c|}
\hline No & Nama Latin & Nama Lokał & $\begin{array}{l}\mathrm{K} \mathrm{K} \\
12 \\
\end{array}$ & $\begin{array}{l}\mathrm{K} \\
3 \\
\end{array}$ & $\frac{K}{4}$ & $\frac{K}{5}$ & $\begin{array}{c}\text { Nilai } \\
\text { Aktual }\end{array}$ & $\begin{array}{c}\text { Nilai } \\
\text { Standar }\end{array}$ & $\begin{array}{c}\text { Nilai Evaluasi } \\
(\%)\end{array}$ & ${ }^{\mathrm{i}}$ Kesesuaian \\
\hline 1 & $\begin{array}{l}\text { Araucaria } \\
\text { heteropylla }\end{array}$ & $\begin{array}{l}\text { Cemara } \\
\text { Norfolk }\end{array}$ & 32 & 2 & 4 & 4 & 15 & 20 & 75 & Sesuai \\
\hline 2 & $\begin{array}{l}\text { Artocarpus } \\
\text { heterophyllus }\end{array}$ & Nangka & 32 & 2 & 4 & 2 & 13 & 20 & 65 & Sesuai \\
\hline 3 & $\begin{array}{l}\text { Canarium } \\
\text { indicum L. }\end{array}$ & Kenari & 44 & 2 & 4 & 4 & 18 & 20 & 90 & Sangat Sesuai \\
\hline 4 & Cerbera manghas & Bintaro & 44 & 3 & 4 & 4 & 19 & 20 & 95 & Sangat Sesuai \\
\hline 5 & $\begin{array}{l}\text { Erythrina } \\
\text { cristagalli }\end{array}$ & $\begin{array}{l}\text { Dadap } \\
\text { Merah }\end{array}$ & 34 & 4 & 3 & 4 & 18 & 20 & 90 & Sangat Sesuai \\
\hline 6 & Ficus benjamina & Beringin & 42 & 3 & 4 & 2 & 15 & 20 & 75 & Sesuai \\
\hline 7 & Ficus lyrata & Biola Cantik & 44 & 3 & 4 & 4 & 19 & 20 & 95 & Sangat Sesuai \\
\hline 8 & $\begin{array}{l}\text { Leucaena } \\
\text { leucocephala }\end{array}$ & Pete cina & 24 & 3 & 3 & 4 & 16 & 20 & 80 & Sesuai \\
\hline 9 & Livistona chinensis & Palem kipas & 14 & 2 & 2 & 4 & 13 & 20 & 65 & Sesuai \\
\hline 10 & Mangifera indica & Mangga & 44 & 2 & 4 & 4 & 18 & 20 & 90 & Sangat Sesuai \\
\hline 11 & Mimusops elengi & Tanjung & 42 & 2 & 3 & 2 & 13 & 20 & 65 & Sesuai \\
\hline 12 & Morinda citrifolia & Mengkudu & 23 & 2 & 2 & 4 & 13 & 20 & 65 & Sesuai \\
\hline 13 & Pinus merkusii & Pinus & 31 & 3 & 4 & 2 & 13 & 20 & 65 & Sesuai \\
\hline 14 & Plumeria sp. & Kamboja & 13 & 3 & 2 & 3 & 12 & 20 & 60 & Kurang Sesuai \\
\hline
\end{tabular}




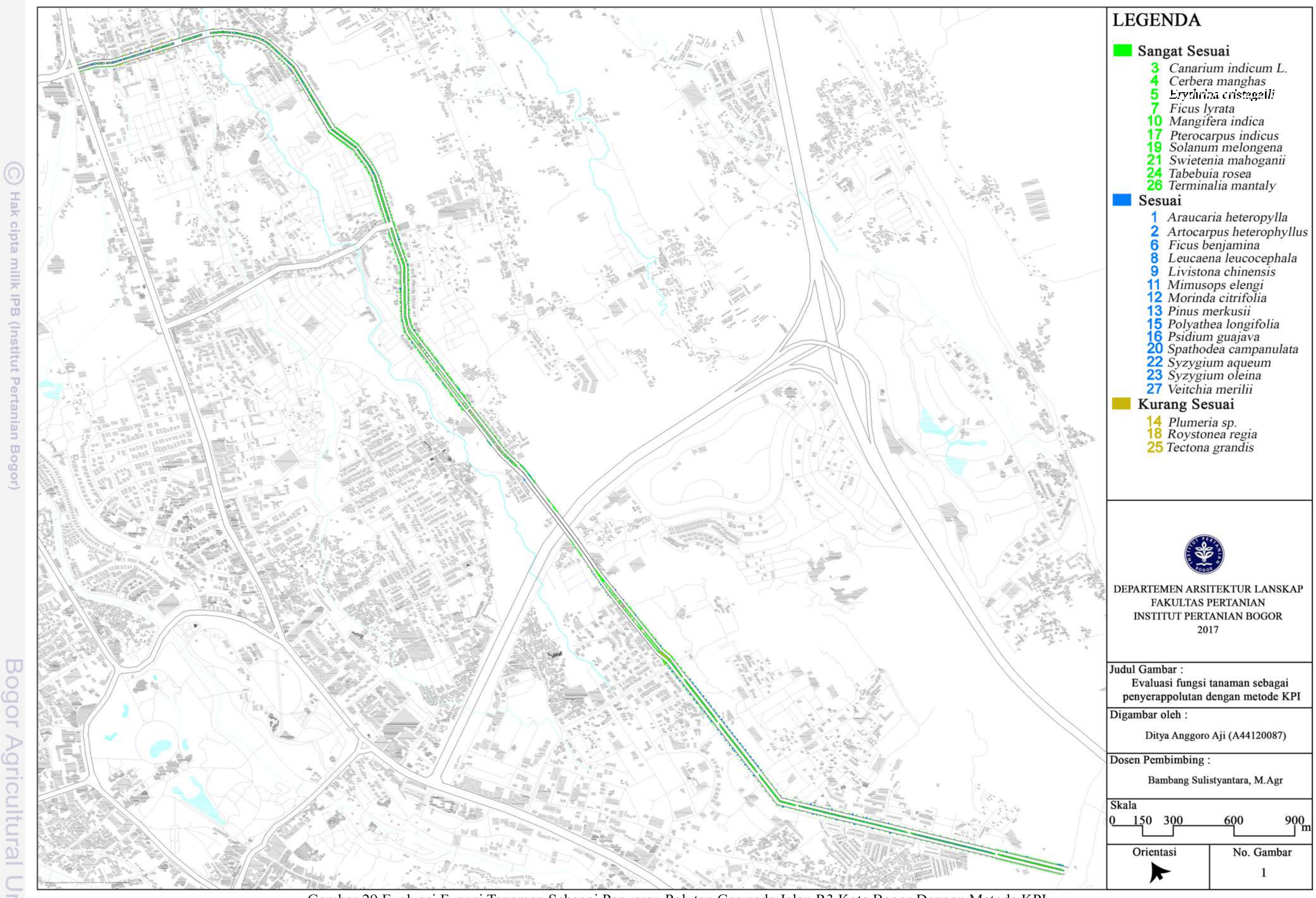

Gambar 29 Evaluasi Fungsi Tanaman Sebagai Penyerap Polutan Gas pada Jalan R3 Kota Bogor Dengan Metode KPI 
Tabel 27 Evaluasi Fungsi Tanaman Menyerap Polutan Gas (Lanjutan)

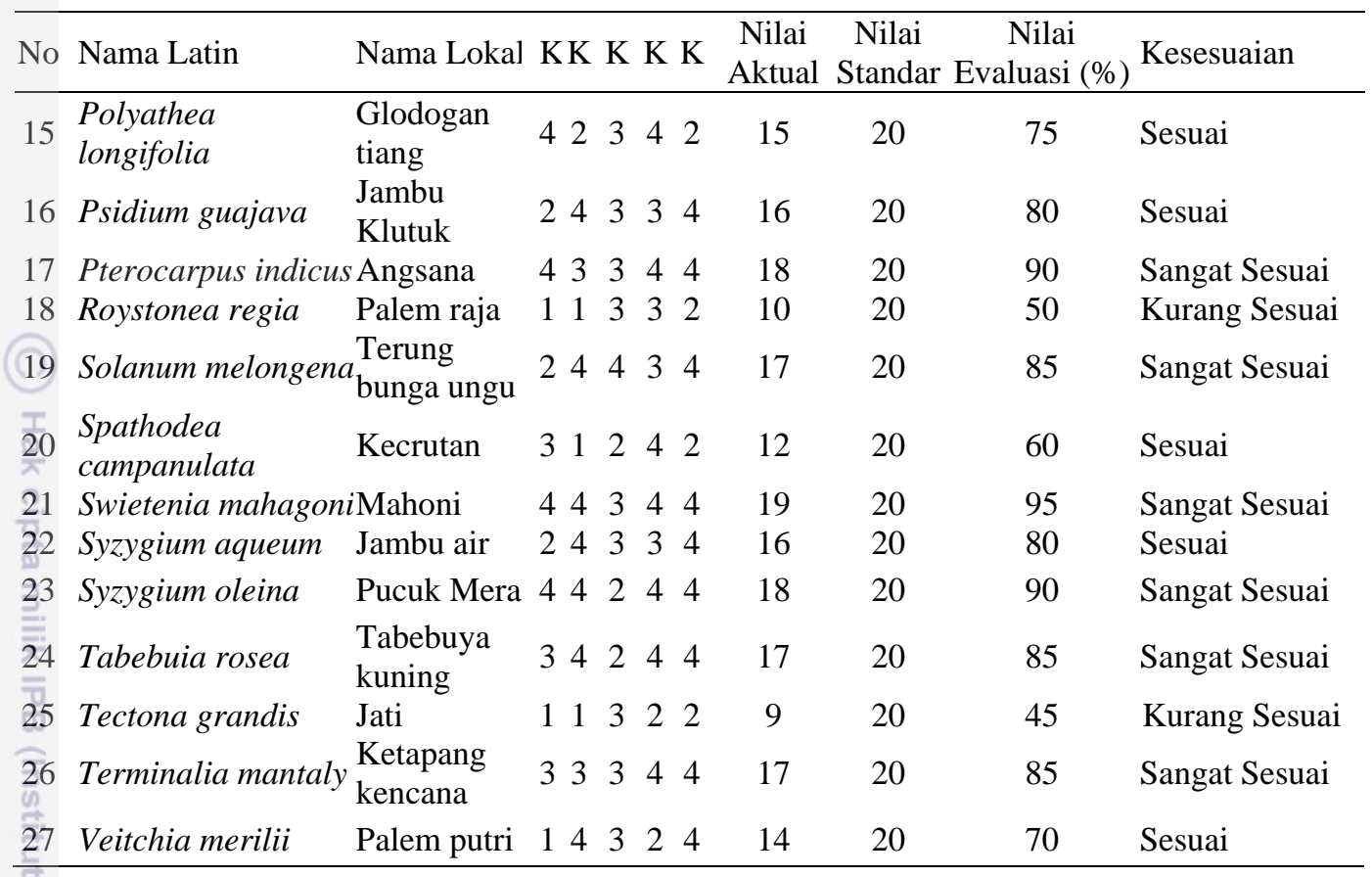

Keterangan : K1 "Kepadatan tajuk", K2 "Kombinasi tanaman", K3 "Ketipisan daun", K4 "Jumlah daun", K5 "Jarak tanam"

Dari penelitian yang telah dilakukan, didapatkan hasil bahwa 11 jenis pohon sangat sesuai untuk penyerap polutan gas, 13 jenis pohon sesuai untuk fungsi penyerap polutan gas, 3 jenis kurang sesuai untuk penyerap polutan gas, dan di sepanjang Jalan R3 Kota Bogor tidak terdapat jenis pohon yang tidak sesuai untuk penyerap polutan gas. Dari hasil ini diketahui bahwa 24 jenis pohon pada jalur hijau Jalan R3 Kota Bogor berpotensi sebagai pereduksi polusi. Kesesuaian tersebut menggambarkan bahwa pohon-pohon tersebut memiliki ciri fisik pada kondisi lapang yang mendukung untuk menyerap polutan gas.

Setelah mendapatkan kesesuaian pohon, dihitung luasan pohon. Luasan jenis pohon untuk masing-masing kategori jenis sangat sesuai, sesuai, kurang sesuai, dan tidak sesuai merupakan gambaran luas jalur hijau jalan untuk tiap kategori tersebut (Tabel 28). Untuk kategori jalur hijau sangat sesuai, 11 jenis pohon yang termasuk kategori sangat sesuai memiliki luas $46105 \mathrm{~m}^{2}$. Luas tersebut menempati 87,4\% dari luas RTH yang dipetakan. Untuk kategori jalur hijau sesuai, 13 jenis pohon yang dikategorikan sesuai memiliki luas $5596 \mathrm{~m}^{2}$ dan memiliki persentase luas $10,6 \%$. Untuk kategori jalur hijau kurang sesuai, 3 jenis pohon memiliki luas $1006 \mathrm{~m}^{2}$ dan luas tersebut memiliki persentase $2 \%$.

Tabel 28 Hasil Evaluasi Kesesuaian Pohon Sebagai Penyerap Polutan Gas

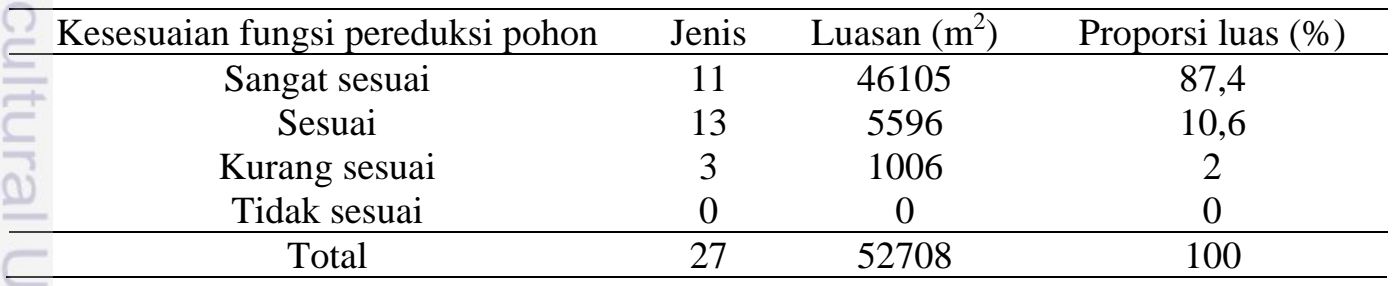


Dari hasil keseluruhan vegetasi yang dipetakan, jalur hijau jalan yang sangat sesuai dan sesuai menempati 87,4\% dan 10,6 \% luas keseluruham. Jumlah luasan kedua kategori ini lebih banyak dibandingkan luas yang kurang sesuai dan tidak sesuai yaitu $2 \%$ dan $0 \%$. Hal ini menunjukkan bahwa pada jalur hijau Jalan R3 Kota Bogor sudah terdapat jenis-jenis vegetasi yang berpotensi untuk menyerap polutan gas.

\section{Rekomendasi}

Hasil rekomendasi merupakan gabungan dari dua analisis, yaitu analisis spasialdan deskriptif. Analisis spasial berupa peta hasil overlay yang menunjukan segmen terbaik yang memiliki vegetasi dengan kemampuan serapan $\mathrm{CO} 2$ yang dapat mengatasi emisi CO2 kendaraan. Analisis deskriptif berupa evaluasi vegetasi yang terdapat pada Jalan R3 Kota Bogor, evaluasi bertujuan untuk mengetahui apakah vegetasi yang ada pada jalan sesuai dengan fungsi vegetasi sebagai penyerap polutan gas. Dari dari dua hasil analisis tersebut dijadikan contoh rekomendasi penanaman vegetasi pada jalan yang sesuai sebagai penyerap polutan gas yaitu polutan $\mathrm{CO} 2$ sebagai fokus dalam peneilitan ini.

Sisa emisi CO2 pada jalan R3 Kota Bogor adalah 3642,413 Kg/ha/jam. Hal itu menunjukkan bahwa emisi $\mathrm{CO} 2$ yang dihasilkan oleh kendaraan belum dapat direduksi dengan baik oleh vegetasi yang tertanam pada Jalan R3 Kota Bogor. Untuk memaksimal kemampuan serapan $\mathrm{CO} 2$ sebaiknya menggunakan jenis vegetasi pohon yang memiliki kemampuan serapan yang tinggi serta penanaman vegetasi yang sesuai dengan kriteria sebagai penyerap polutan gas. Hal itu dilakukan agar kemampuan serapan emisi $\mathrm{CO} 2$ dapat mereduksi emisi $\mathrm{CO} 2$ dengan baik.

\section{Segmen Terbaik}

Segmen 6 dikategorikan sebagai segmen terbaik, hal itu dikarenakan vegetasi pada segmen 6 memiliki kemampuan serapan emisi CO2 sebesar 117,61 $\mathrm{kg} / \mathrm{ha} / \mathrm{jam}$, angka tesebut merupakan nilai serapan terbesar dibandingkan dengan angka serapan di segmen lainnya (Gambar 30). Vegetasi yang tertanam pada segmen 6 juga tergolong sangat banyak serta memiliki pola penanaman yang rapat. Foto kondisi tapak segmen 6 dapat dilihat pada Gambar 33,

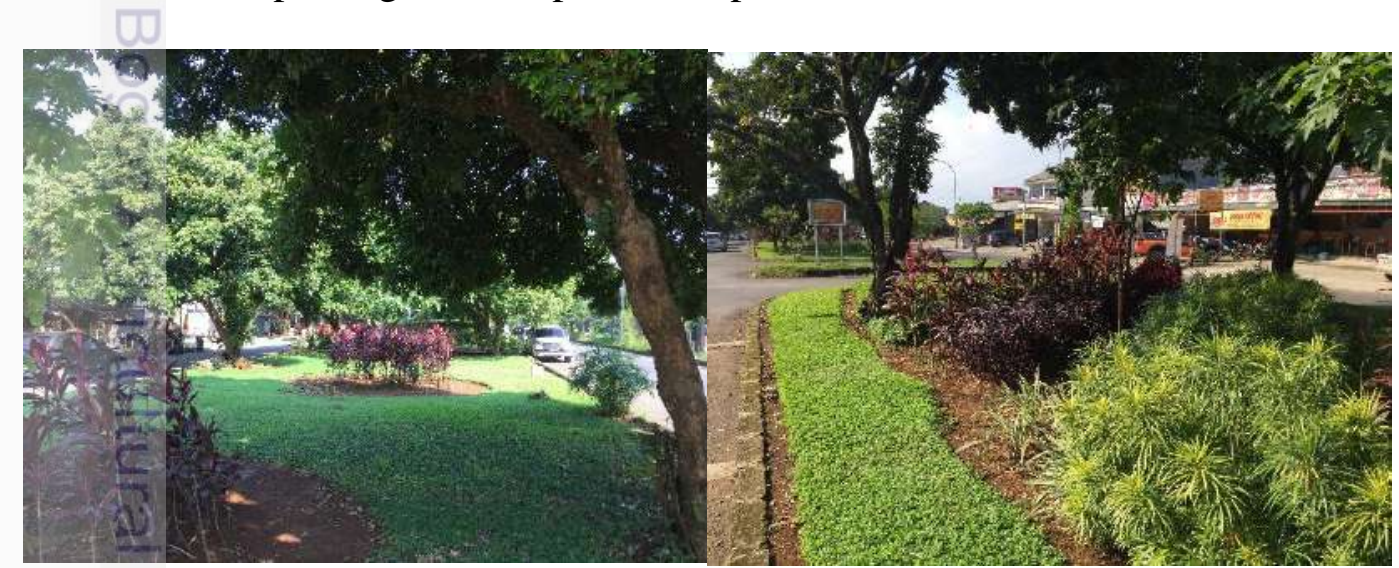

Gambar 33 Foto Kondisi Penanaman di Segmen 6 
Tingginya nilai serapan vegetasi terhadap emisi CO2 pada segmen 6 dipengaruhi oleh banyaknya jumlah vegetasi yang tertanam, jenis pohon yang ditanam juga memiliki tajuk pohon yang lebar, dan penanaman vegetasi yang rapat. Selain itu vegetasi pada segmen 6 ditanam dengan kombinasi penanaman pohon, perdu dan semak. Dimensi tepi jalan pada segmen 6 memiliki lebar $12 \mathrm{~m}$, hal tersebut tergolong lebar dibandingkan dengan lebar tepi segmen-segmen lainnya.

Terdapat 520 pohon yang tertanam pada segmen 6 dan dari jumlah tesebut terdapat 11 jenis pohon (Tabel 18). 4 jenis pohon yang sangat dominan yaitu jenis pohon kamboja (Plumeria rubra), terung bunga ungu (Solanum melongena), mahoni (Swietenia mahogani) dan pucuk merah (Syzygium oleina). Pohon jenis terung bunga ungu (Solanum melongena) tersebar cukup banyak di median jalan, sedangkan jenis pohon mahoni (Swietenia mahogani) dan pucuk merah (Syzygium oleina) tersebar di medan serta tepi jalan pada segmen 6. Untuk jenis pohon kamboja (Plumeria rubra) yang tersebar juga di median dan tepi jalan terdapat 3 jenis kamboja dengan warna bunga yang berbeda, yaitu kamboja bunga kuning, kamboja bunga merah dan kamboja bunga pink.

Walaupun emisi $\mathrm{CO} 2$ belom tereduksi dengan baik, namun hal tersebut dapat dikendalikan dengan penanaman vegetasi yang sesuai. Segmen 6 dijadikan contoh ruang terbuka hijau jalan yang sebaiknya aplikasikan pada segmen lainnya karena memiliki nilai serapan tertinggi. Namun, untuk lebih meningkatkan nilai serapan $\mathrm{CO} 2$ pada segmen 6 maka perlu dilakukannya replanting atau penanaman ulang untuk meningkatkan kemampuan serapan $\mathrm{CO} 2$.

\section{Vegetasi Sebagai Penyerap Polutan Gas pada Jalan R3}

Pemilihan vegetasi untuk tujuan kontrol polusi perlu memperhatikan beberapa hal yaitu tipe pohon, tajuk pohon, tingkat pertumbuhan, karakteristik daun, dan toleransi terhadap polusi udara. Tipe pohon evergreen umumnya memiliki tingkat efisiensi yang lebih tinggi dalam membersihkan polutan udara karena masa hidup yang lebih lama. Dimensi atau besar pohon menggambarkan jumlah karbon dioksida yang dapat disimpan serta luas permukaan untuk intersepsi dan deposisi Tingkat pertumbuhan pohon mempengaruhi penyimpanan tahunan karbondioksida dan ukuran permukaan tajuk fungsional untuk pembersihan polutan udara. Tanaman dengan tingkat pertumbuhan yang cepat dapat menyimpan karbondioksida serta menyediakan permukaan penyerap polusi udara lebih awal dibanding dengan tanaman lainnya. Karakter daun suatu tanaman akan mempengaruhi tingkat resapan polutan. Daun yang berselaput, perkamen, dan halus dapat menyerap polusi lebih baik dibanding daun yang kasar.

Walaupun emisi CO2 merupakan fokus polutan pada penelitian ini, namun dalam mengevaluasi vegetasi sesuai dengan kriteria sebagai penyerap polutan gas berlaku untuk semua jenis polutan pencemar, contoh tanaman sebagai penyerap polutan terlampir pada Tabel lampiran 3 dan 4 . Jenis pohon untuk fungsi menyerap polutan gas ketahanan terhadap jenis polutan udara, memiliki kemampuan dalam mengurangi pencemar udara, berdaun sepanjang tahun, tajuk rapat, berdaun banyak, dan penanaman yang dikombinasikan dengan semak dan perdu.

Hasil evaluasi vegetasi sebagai penyerap polutan gas menunjukkan terdapat kategori vegetasi yang sangat sesuai, sesuai, kurang sesuai, dan tidak sesuai. Kategori-kategori dari rekomendasi tanamaan tersebut akan dijelaskan sebagai berikut: 


\section{a. Kategori Sangat Sesuai}

Kategori vegetasi jalur hijau ini memenuhi kriteria-kriteria untuk fungsi menyerap polutan gas. Pada jalur hijau Jalan R3 Kota Bogor, vegetasi yang sangat sesuai terdapat $87,4 \%$ dari luas vegetasi. Hasil ini menunjukkan, kondisi penanaman saat ini sudah cukup baik untuk fungsi menyerap polutan gas. Vegetasi jenis ini diharapkan dipertahankan karena memiliki potensi yang baik dalam menyerap polutan gas. Terdapat 11 jenis pohon yang termasuk ke dalam kategori sangat sesuai, yaitu kenari (Canarium indicum L.), bintaro (Cerbera manghas), dadap merah (Erythrina cristagalli), biola cantik (Ficus lyrata), mangga (Mangifera indica), angsana (Pterocarpus indicus), terung bunga ungu (Solanum melongena), mahoni (Swietenia mahogani), pucuk merah (Syzygium oleina), tabebuya kuning (Tabebuia rosea), dan ketapang kencana (Terminalia mantaly).

\section{b. Kategori Sesuai}

Kategori vegetasi jalur hijau jalan ini memenuhi sebagian besar kriteria untuk menyerap polutan gas. Persentase luas jalur hijau jalan yang sesuai yaitu 10,6\%. Sama seperti kategori sebelumnya, vegetasi jalur hijau jalan ini pun berpotensi dalam menyerap polutan gas dan diharapkan dipertahankan. Terdapat 13 jenis pohon yang termasuk ke dalam kategori sesuai, yaitu cemara Norfolk (Araucaria heteropylla), nangka (Artocarpus heterophyllus), beringin (Ficus benjamina), pete cina (Leucaena leucocephala), palem kipas (Livistona chinensis), tanjung (Mimusops elengi), mengkudu (Morinda citrifolia), pinus (Pinus merkusii), glodogan tiang (Polyathea longifolia), jambu klutuk (Psidium guajava), kecrutan (Spathodea campanulata), palem putri (Veitchia merilii), dan jambu air (Syzygium aqueum).

\section{c. Kategori Kurang Sesuai}

Vegetasi kategori kurang sesuai memiliki luasan 2\% dari jalur hijau jalan. Jalur hijau jalan kategori kurang sesuai tidak memenuhi beberapa kriteria untuk menyerap polutan gas. Walaupun demikian, jalur hijau jalan ini cukup berpotensi untuk menyerap polutan gas. Fungsi jalur hijau jalan untuk menyerap polutan gas dapat dioptimalkan dengan penanaman jarak tanam pohon yang rapat. Selain itu, dapat juga menambahkan penanaman tanaman semak atau perdu. Terdapat 3 jenis pohon yang termasuk ke dalam kategori kurang sesuai, yaitu kamboja (Plumeria Sp.), palem raja (Roystonea regia), dan jati (Tectona grandis).

\section{d. Kategori Tidak Sesuai}

Kategori jalur hijau jalan ini tidak memenuhi sebagian besar kriteria untuk menyerap polutan gas. Di sepanjang Jalan R3 Kota Bogor tidak terdapat jenis vegetasi yang termasuk ke dalam kategori jenis vegetasi yang tidak sesuai untuk menyerap polutan gas. Namun pemanfaatan jalur hijau jalan kategori ini untuk fungsi menyerap polutan gas dapat dilakukan dengan penambahan pohon, perdu, atau semak. Jenis yang dipilih yaitu jenis yang memiliki ketahanan tinggi terhadap polusi udara dan juga bermassa daun padat. Penanaman dilakukan pada jarak tanam yang rapat.

Untuk fungsi reduksi polusi, pemilihan jenis vegetasi sebaiknya mempertimbangkan ketahanan tanaman terhadap polusi udara. Berdasarkan studi literatur diketahui bahwa jenis pohon yang berdaun kecil namun jumlah daunnya 
banyak dapat menyerap gas pencemar lebih baik dibanding tanaman berdaun lebar tapi jumlah daunnya sedikit. Pohon dengan tajuk padat lebih efektif dalam mereduksi polusi. Pohon untuk mereduksi polusi dapat dipilih jenis yang toleran. Jenis pohon yang sensitif terhadap polutan tertentu sebaiknya tidak ditanam dekat dengan sumber polusi.

Penanaman vegetasi dapat dilakukan dalam beberapa lapis tanaman karena area penyangga yang lebih tebal dapat mereduksi polusi dengan lebih baik. Selain itu, penanaman dilakukan kontinyu dan dapat mengkombinasikan pohon dengan semak dan groundcover. Dengan adanya kombinasi antara pohon, perdu, semak dan groundcover terjadi strata vegetasi secara vertikal. Pepohonan yang lebih tinggi dapat menangkap zat pencemar pada lokasi yang lebih tinggi dan semak dapat menyerap dan menangkap zat pencemar udara pada ketinggian yang lebih rendah.

Peraturan pemerintah juga telah mengeluarkan aturan yang menyinggung ruang terbuka hijau jalan sebagai fasilitas untuk mengatasi polusi yang terdapat pada jalan. Hal tersebut terdapat di peraturan pemerintah tahun 2008 nomor 5 yang dijelaskan dalam bentuk bentuk pola penanaman vegetasi, gambar tersebut dapat dilihat di Gambar 34.

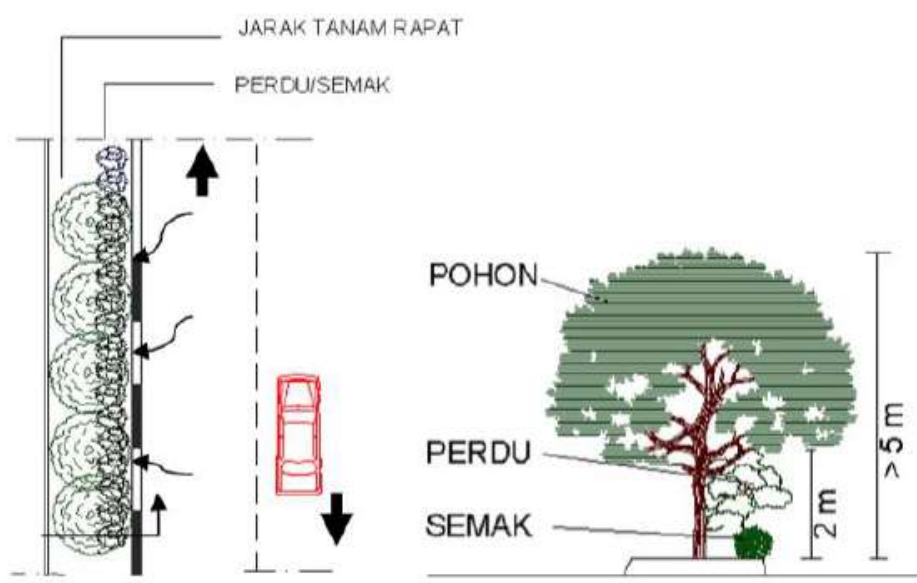

Gambar 34 Jalur Hijau Jalan Untuk Menyerap Polusi Udara (PP No. 5 tahun 2008)

\section{Rekomendasi Jenis Tanaman}

Rekomendasi penanaman merupakan gabungan contoh penanaman sebagai penyerap polutan gas berdasarkan dari hasil dua analisis yang dilakukan pada penelitian ini. Dari hasil penelitian, segmen 6 merupakan segmen dengan kamampuan serapan $\mathrm{CO} 2$ tertinggi dan beberapa jenis pohon pada segmen 6 diketahui juga termasuk dalam kategori pohon yang sangat sesuai dan sesuai sebagai penyerap polutan gas. Jenis pohon pada segmen 6 yang termasuk kedalam kategori sangat sesuai sebagai penyerap polutan gas dapat dilihat pada Tabel 29.

Tabel 29 Jenis Pohon Kategori Sangat Sesuai dan Sesuai pada segmen 6

\begin{tabular}{lllcc} 
No Nama Latin & Nama Lokal & Jumlah & $\frac{\text { Lokasi }}{\text { Tepi Median }}$ \\
\hline 1 & Cerbera manghas & Bintaro & 1 & $\mathrm{v}$ \\
2 & Erythrina cristagalli & Dadap merah & 12 & \\
\hline
\end{tabular}


Tabel 29 Jenis Pohon Kategori Sangat Sesuai dan Sesuai pada Segmen 6 (Lanjutan)

\begin{tabular}{cllccc}
\hline \multirow{2}{*}{ No Nama Latin } & Nama Lokal & Jumlah & \multicolumn{2}{c}{ Lokasi } \\
\hline 3 & Ficus benjamina & Beringin & 16 & $\mathrm{v}$ & \\
4 & Leucaena leucocephala & Pete cina & 3 & $\mathrm{v}$ & \\
5 & Mangifera indica & Mangga & 7 & $\mathrm{v}$ & \\
6 & Mimusops elengi & Tanjung & 6 & $\mathrm{v}$ & \\
7 & Pterocarpus indicus & Angsana & 22 & $\mathrm{v}$ & \\
8 & Solanum melongena & Terung bunga ungu & 24 & & $\mathrm{v}$ \\
9 & Swietenia mahogani & Mahoni & 176 & $\mathrm{v}$ & $\mathrm{v}$ \\
10 & Syzygium oleina & Pucuk Merah & 162 & $\mathrm{v}$ & $\mathrm{v}$ \\
\hline
\end{tabular}

Jenis pohon yang termasuk dalam kategori sangat sesuai dan sesuai pada segmen 6 diketahui juga memiliki kemampuan menyerap $\mathrm{CO} 2$. Berdasarkan hasil penelitian Duryatno dan Sardi (Lampiran 5) jenis-jenis pohon tersebut yaitu beringin (Ficus benjamina), mahoni (Swietenia mahoganii), dadap merah (Erythrina cristagalli), tanjung (Mimusoph elengi), dan angsana (Pterocarpus indicus). Angka nilai kemampuan serapan $\mathrm{CO} 2$ pohon pada segmen 6 berdasarkan penelitian Duryatno dan Sardi dapat dilihat di Tabel 30.

Tabel 30 Nilai Serapan CO2 pada Segmen 6

\begin{tabular}{lllc}
\hline No & Nama Latin & Nama Lokal & $\begin{array}{c}\text { Daya serap CO2 } \\
\text { (kg/pohon/hari) }\end{array}$ \\
\hline 1 & Ficus benjamina & Beringin & 1,468 \\
2 & Swietenia mahoganii & Mahoni & 0,810 \\
3 & Mimusoph elengi & Tanjung & 0,094 \\
4 & Pterocarpus indicus & Angsana & 0,030 \\
5 & Erythrina cristagalli & Dadap merah & 0,012 \\
\hline
\end{tabular}

Sumber : Duryatmo dan Sardi (2008)

Pohon diketahui sebagai vegetasi yang memiliki kemampuan penyerap polutan paling tinggi dibandingkan jenis vegetasi lainnya. Jenis-jenis pohon pada segmen 6 diketahui termasuk dalam katergori sangat sesuai sebagap penyerap polutan gas, namun berdasarkan penelitian duryatmo dan Sardi tahun 2008, untuk meningkat kemampuan serapan $\mathrm{CO} 2$ pada segmen sebaiknya menambahkan vegetasi pohon seperti trembesi (Samanea saman) dengan serapan 78,05 $\mathrm{kg} /$ pohon/hari, cassia (Cassia sp.) dengan serapan 14,50 kg/pohon/hari, dan beringin (Ficus benjamina) dengan serapan 1,468 kg/pohon/hari dan mahoni (Swietenia mahoganii) dengan serapan $0,810 \mathrm{~kg} / \mathrm{pohon} / \mathrm{hari}$.

Jenis vegetasi lainnya seperti semak, perdu, dan groundcover pada segmen 6 juga diketahui memiliki kemampuan sebagai penyerap polutan. Berdasarkan litelatur beberapa jenis semak dan groundcover pada segmen 6 diketahui memiliki kemampuan serapan. (Nasrullah et al, 2008), jenis yang terdapat pada segmen 6 yaitu hanjuang merah (Cordyline terminalis) dan miana hijau kuning (Coleus blumei). 


\section{Rekomendasi Penanaman}

Rekomendasi difokuskan pada bagian median jalan pada segmen 6, hal itu dilakukan karena pda median jalan memiliki luasan yang lebih lebar dibandingkan tepi jalan, sehingga dapat diasumsikan bahwa median jalan merupakan bagian ruang terbuka hijau jalan yang lebih maksimal dalam mereduksi polutan CO2. Segmen 6 dengan penambahan jenis vegetasi yang sesuai sebagai penyerap $\mathrm{CO} 2$ diharapkan mampu mengendalikan emisi $\mathrm{CO} 2$ yang dihasilkan oleh kendaraan dan hasil rekomendasi dapat digunakan untuk contoh penanaman pada segmen atau jalan lainnya

Peta hasil rekomendasi hanya berbentuk replanting atau rekomendasi jenis tanaman yang diganti untuk meningkatkan kemampuan ruang terbuka hijau jalan $\mathrm{R} 3$ sebagai penyerap polutan $\mathrm{CO} 2$. Namun tidak semua vegetasi di rekomendasikan untuk diganti, ada beberapa vegetasi pada median segmen 6 dipertahankan karena memiliki kemampuan serapan polutan serta memilki nilai evaluasi yang dikategorikan sangat baik. Perlakuan penanaman vegetasi pada median segmen 6 dapat dilihat pada Tabel 31.

Tabel 31 Perlakuan Vegetasi Pada Median Segmen 6

\begin{tabular}{|c|c|c|c|}
\hline No & Nama Latin & Nama Lokal & Perlakuan \\
\hline \multicolumn{4}{|c|}{ Pohon } \\
\hline 1 & Solanum melongena & Terung bunga ungu & Dipertahakan \\
\hline 2 & Swietenia mahogani & Mahoni & Dipertahakan \\
\hline 3 & Syzygium oleina & Pucuk Merah & Di ganti \\
\hline 4 & Plumeria sp. & Kamboja & Di ganti \\
\hline \multicolumn{4}{|c|}{ Perdu } \\
\hline 1 & Heleconia sp. & Heleconia & Dipertahakan \\
\hline \multicolumn{4}{|c|}{ Semak } \\
\hline 1 & Alpinia sp. & Honje belang & Dipertahakan \\
\hline 2 & Cordyline terminalis & Hanjuang merah & Dipertahakan \\
\hline 3 & Dianella variegata & Dianella & Dipertahakan \\
\hline 4 & Ixora dwarf & Soka mini putih & Dipertahakan \\
\hline 5 & Osmoxylon lineare & Aralia laba laba & Dipertahakan \\
\hline 6 & Pseuderanthemum reticulatum & Melati jepang & Dipertahakan \\
\hline 7 & Tabernaemontana dwarf & Melati tarbenia mini & Dipertahakan \\
\hline \multicolumn{4}{|c|}{ Groundcover } \\
\hline 1 & Barleria prionitis $L$. & Landep & Dipertahakan \\
\hline 2 & Chrysanthemum sp & Seruni jalar & Dipertahakan \\
\hline 3 & Coleus blumei & Miana hijau kuning & Dipertahakan \\
\hline 4 & Ophiopoghon variegata & Alang alang putih & Dipertahakan \\
\hline 5 & Pandanus pygmaeus & Pandan kuning & Dipertahakan \\
\hline
\end{tabular}

Hasil akhir penelitian merupakan peta rekomendasi penanaman dalam bentuk tampak atas dan tampak potongan. Hal itu dilakukan agar memperjelas bentuk penanaman pada segmen 6 dan juga mempermudah dalam memasukan informasi rekomendasi pada setiap peta yang telah dihasilkam. Peta hasil rekomendasi pada segmen 6 dapat dilihat pada Gambar 35, Gambar 36, Gambar 37, Gambar 38, Gambar 39, Gambar 40, Gambar 41, Gambar 42, Gambar 43, Gambar 44, Gambar 45, Gambar 46, Gambar, Gambar 47, Gambar 48 dan Gambar 49. 


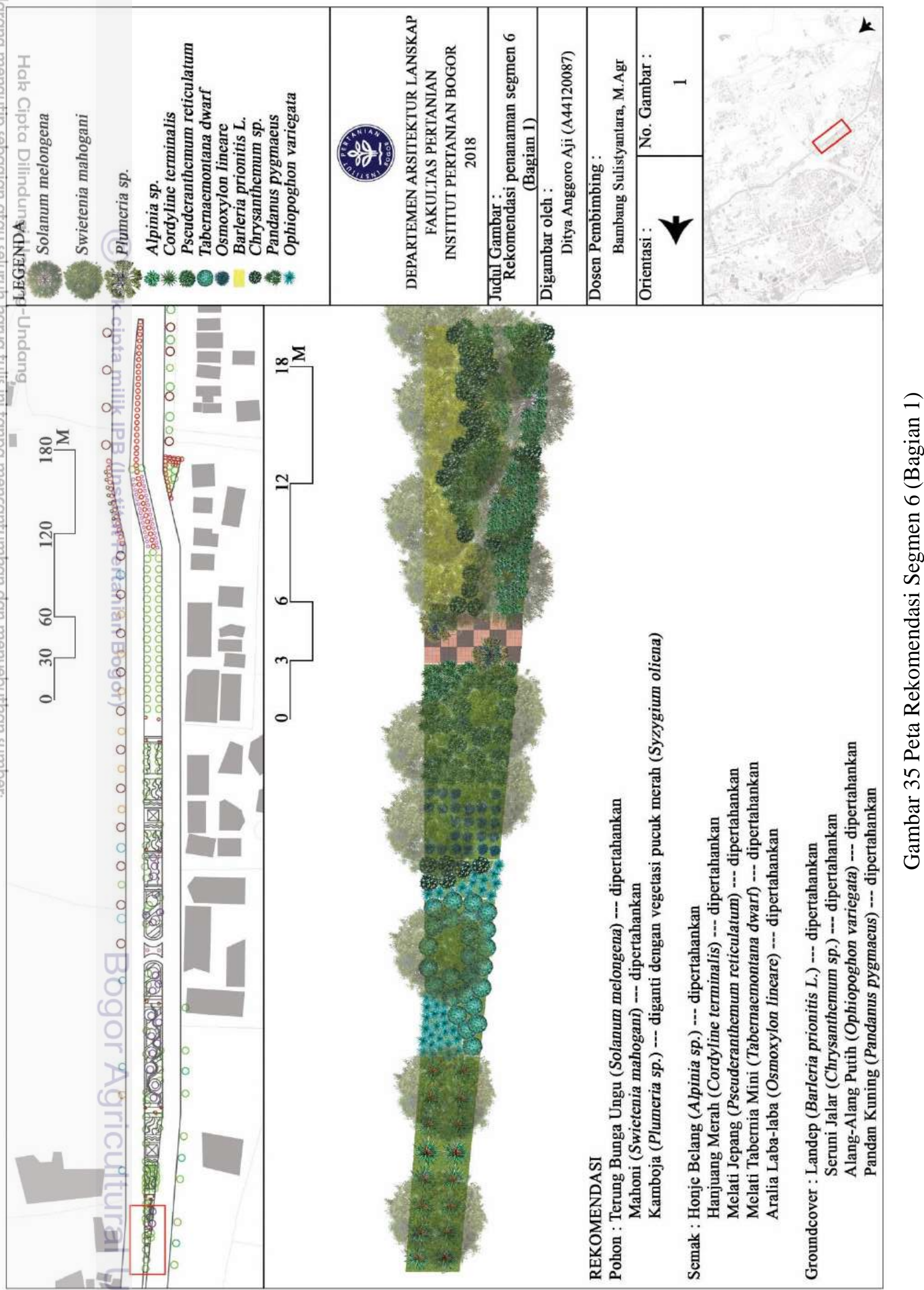




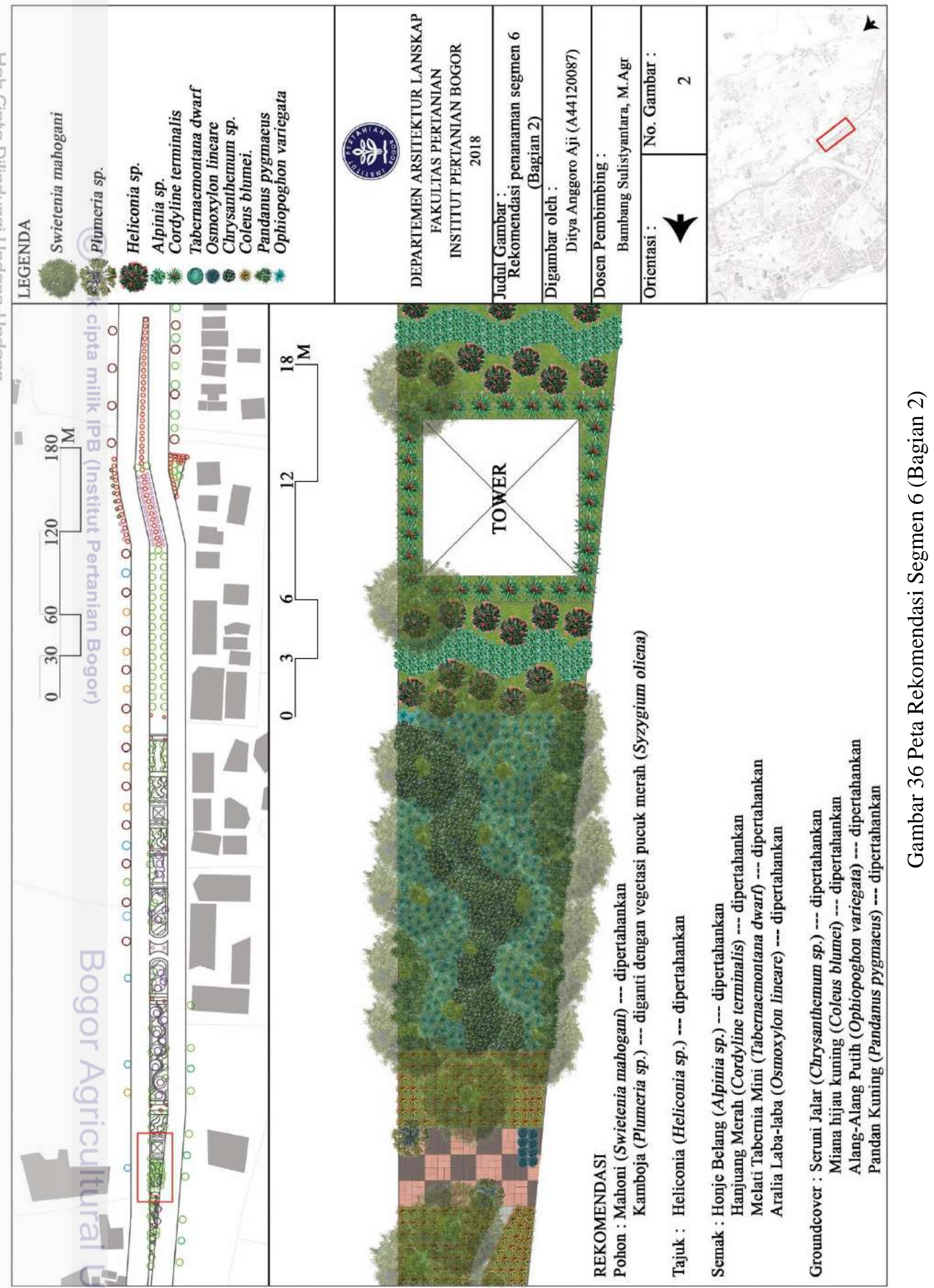




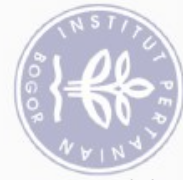

66

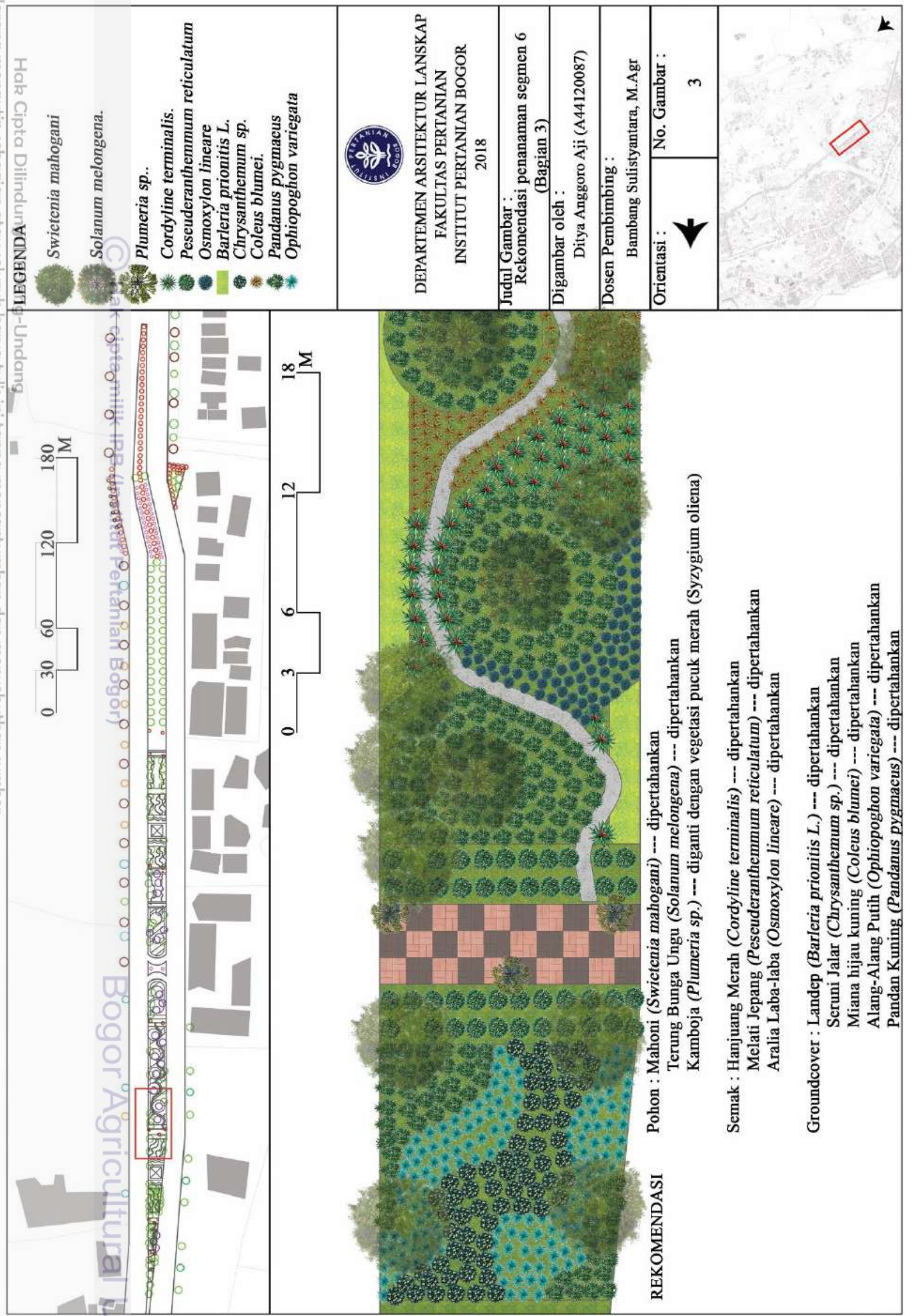

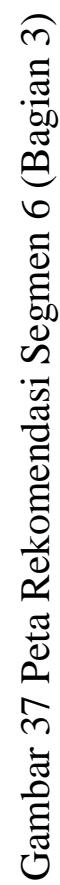




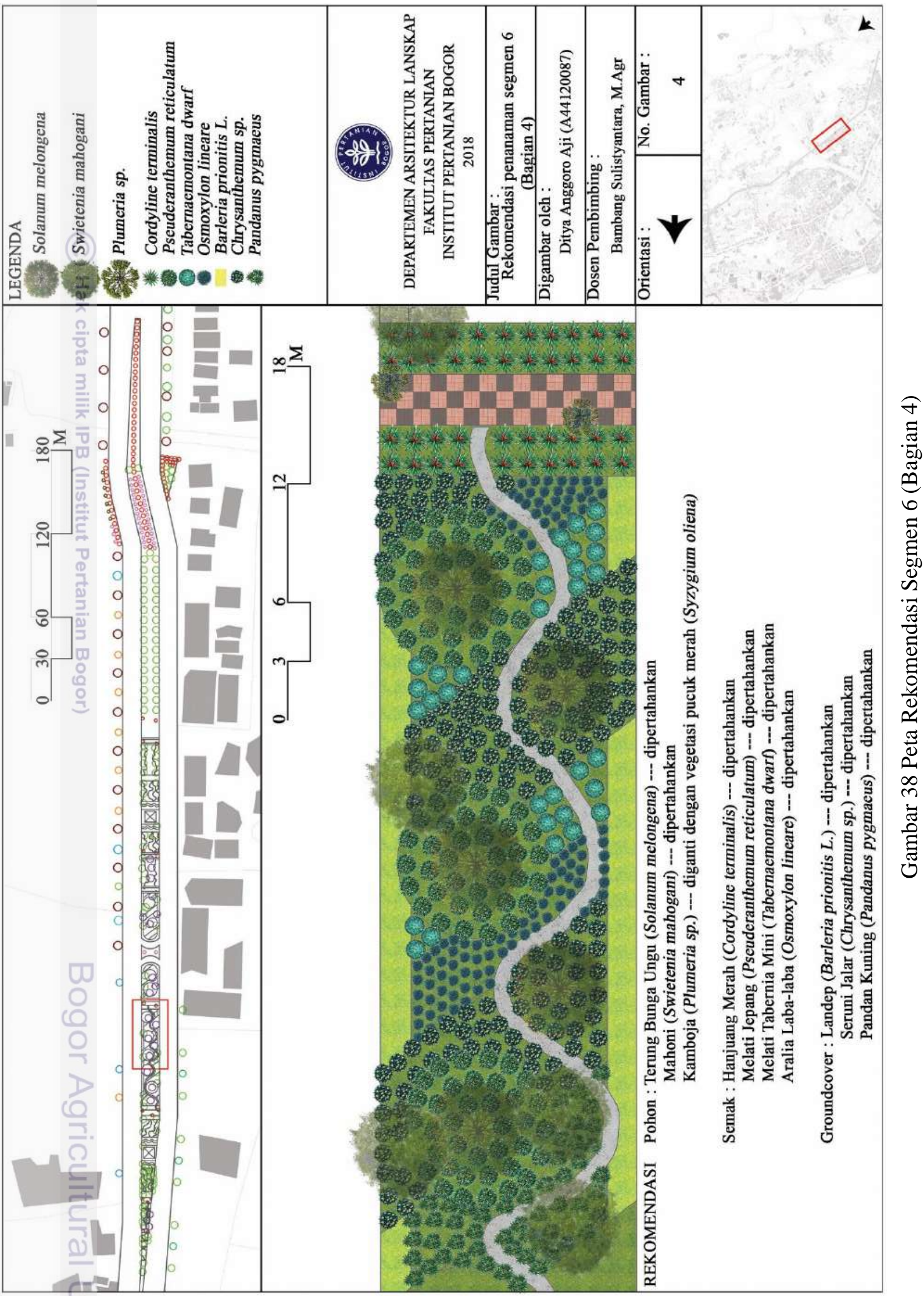




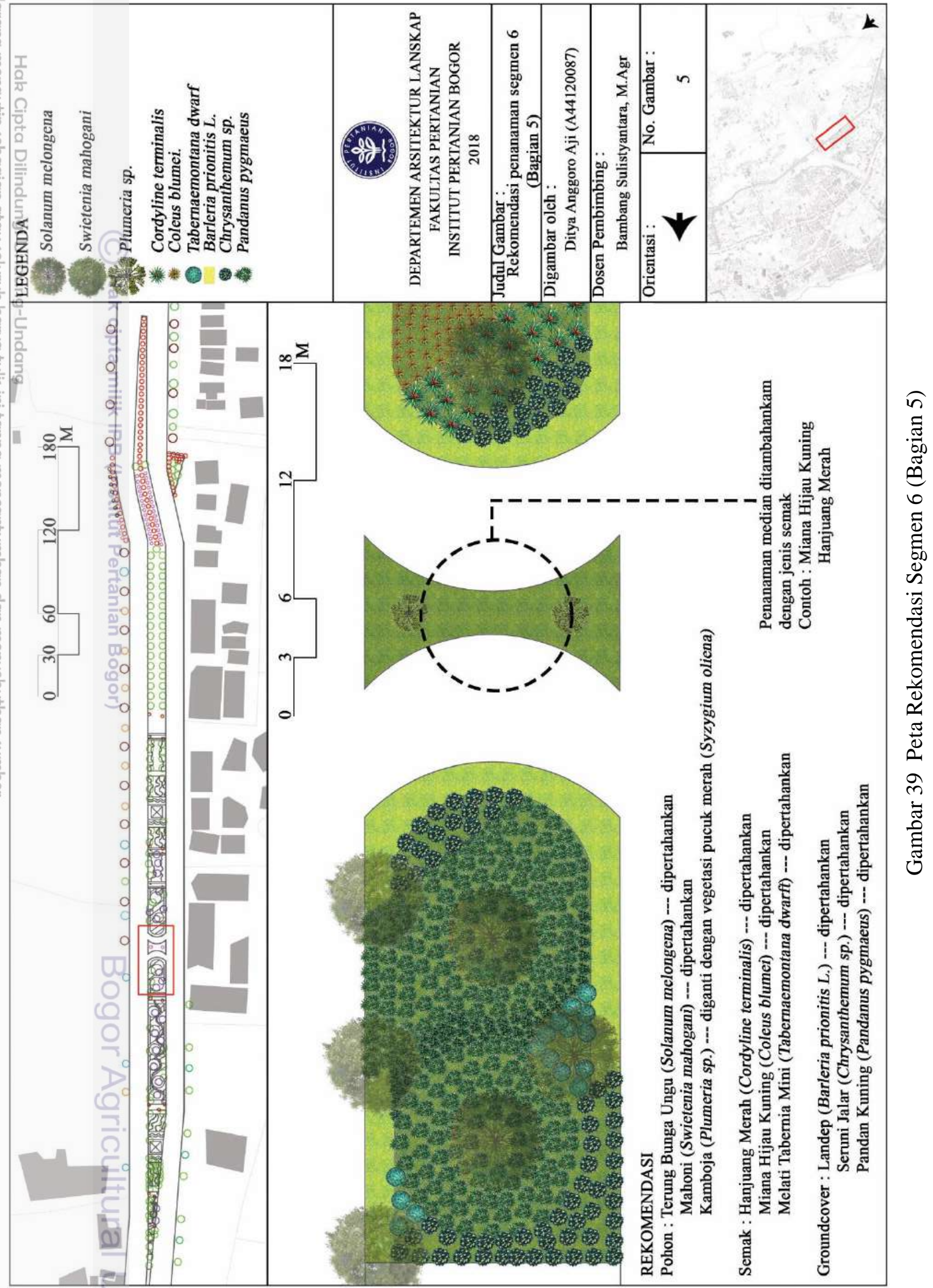




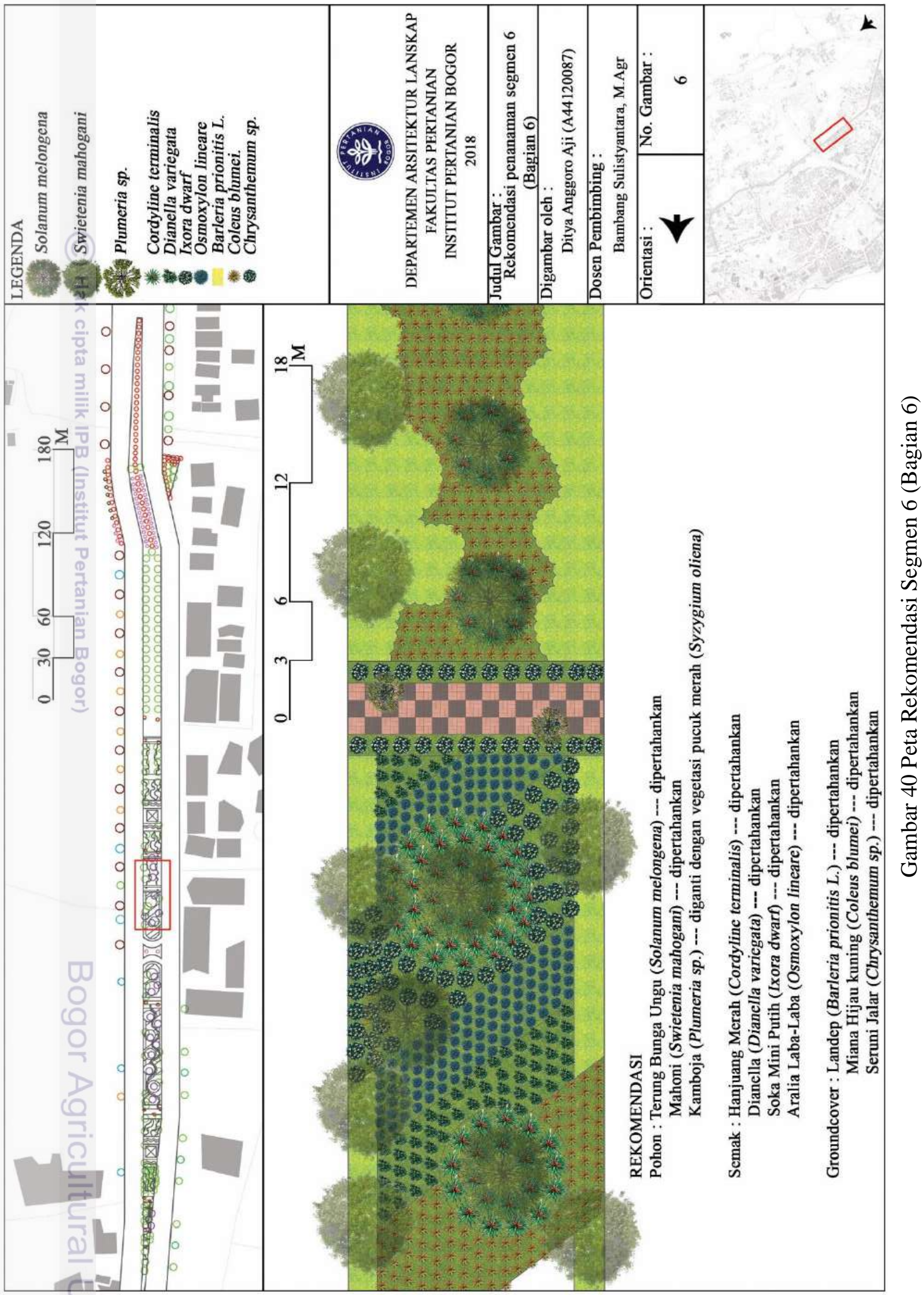




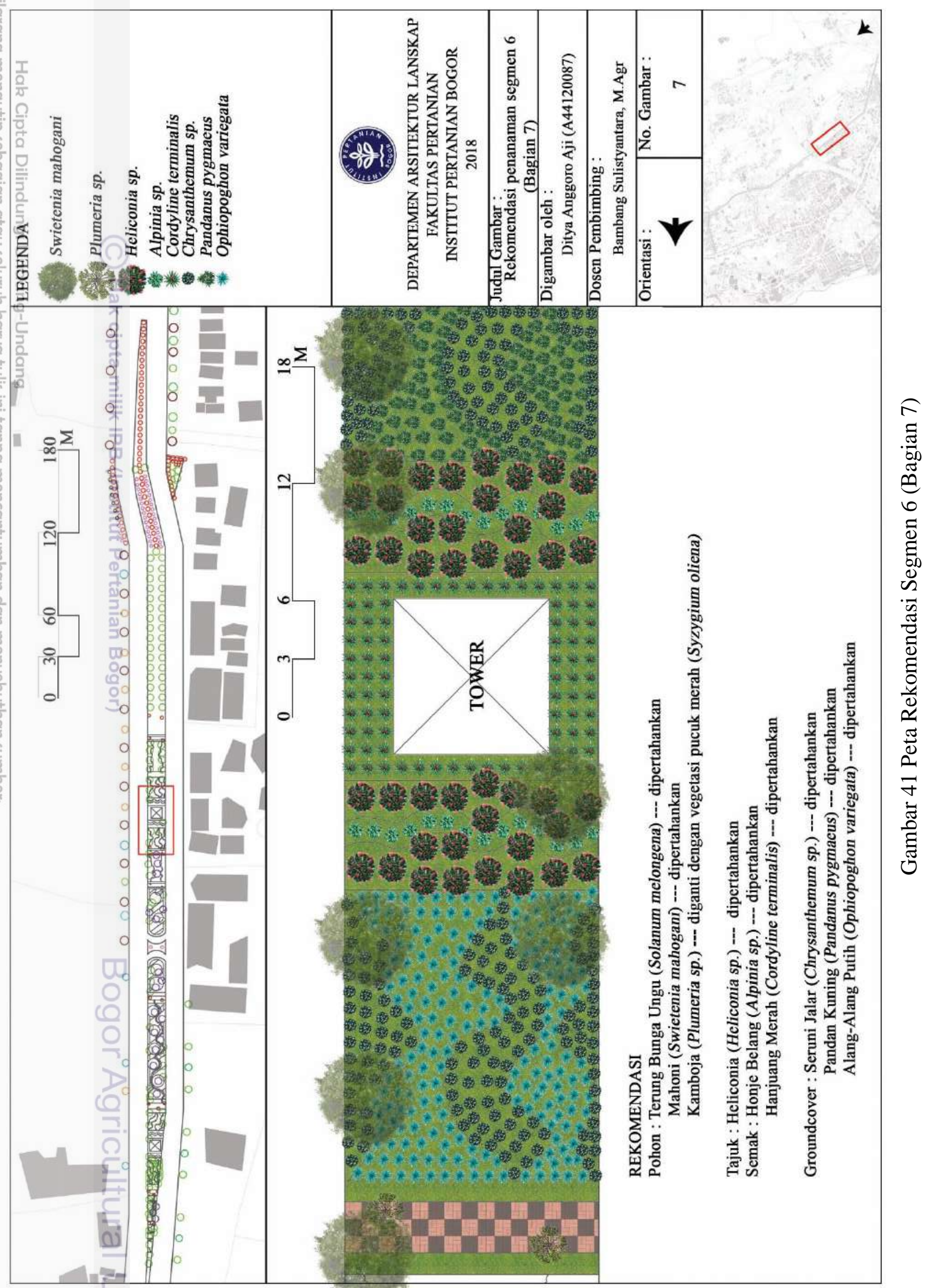




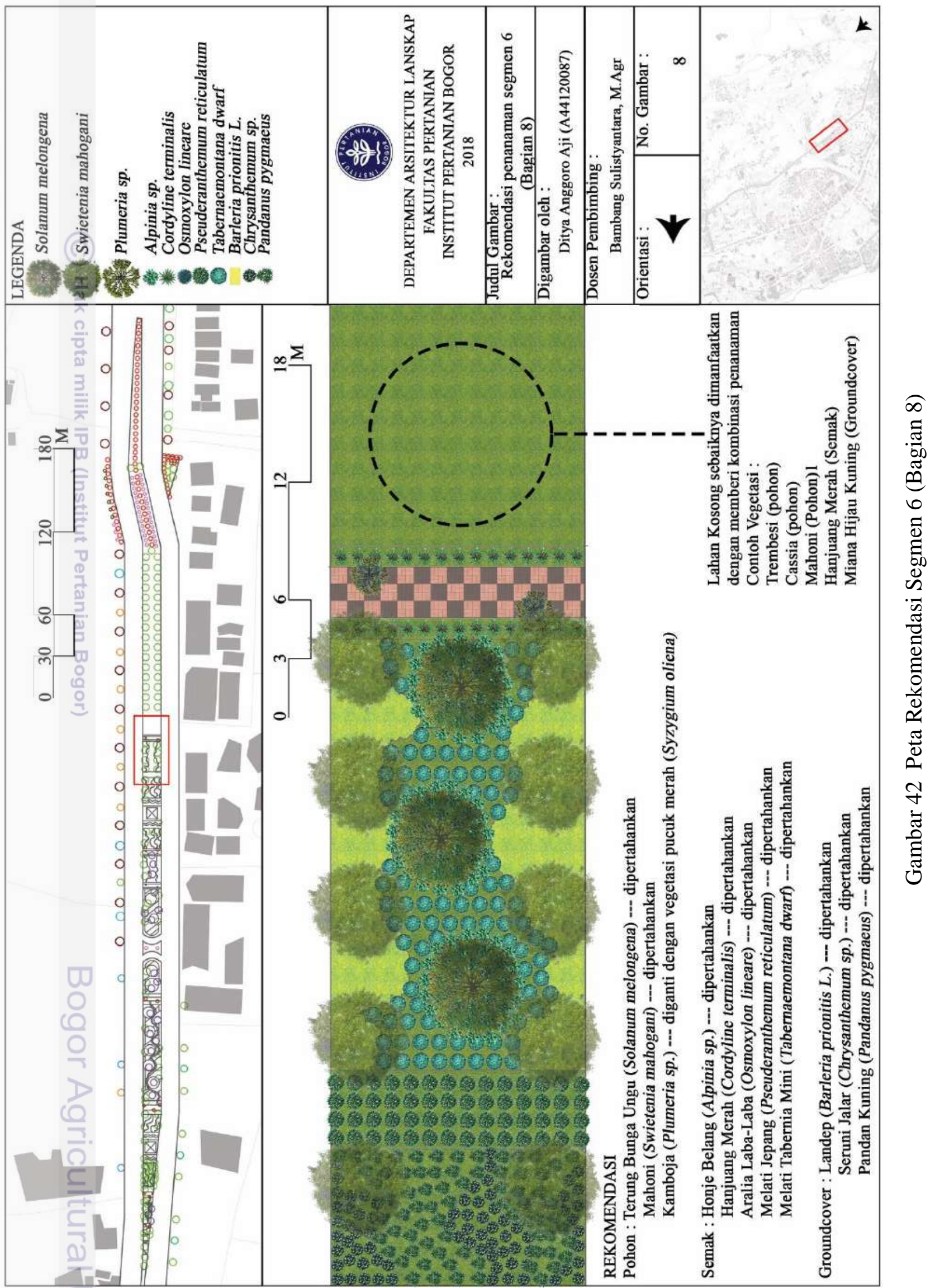




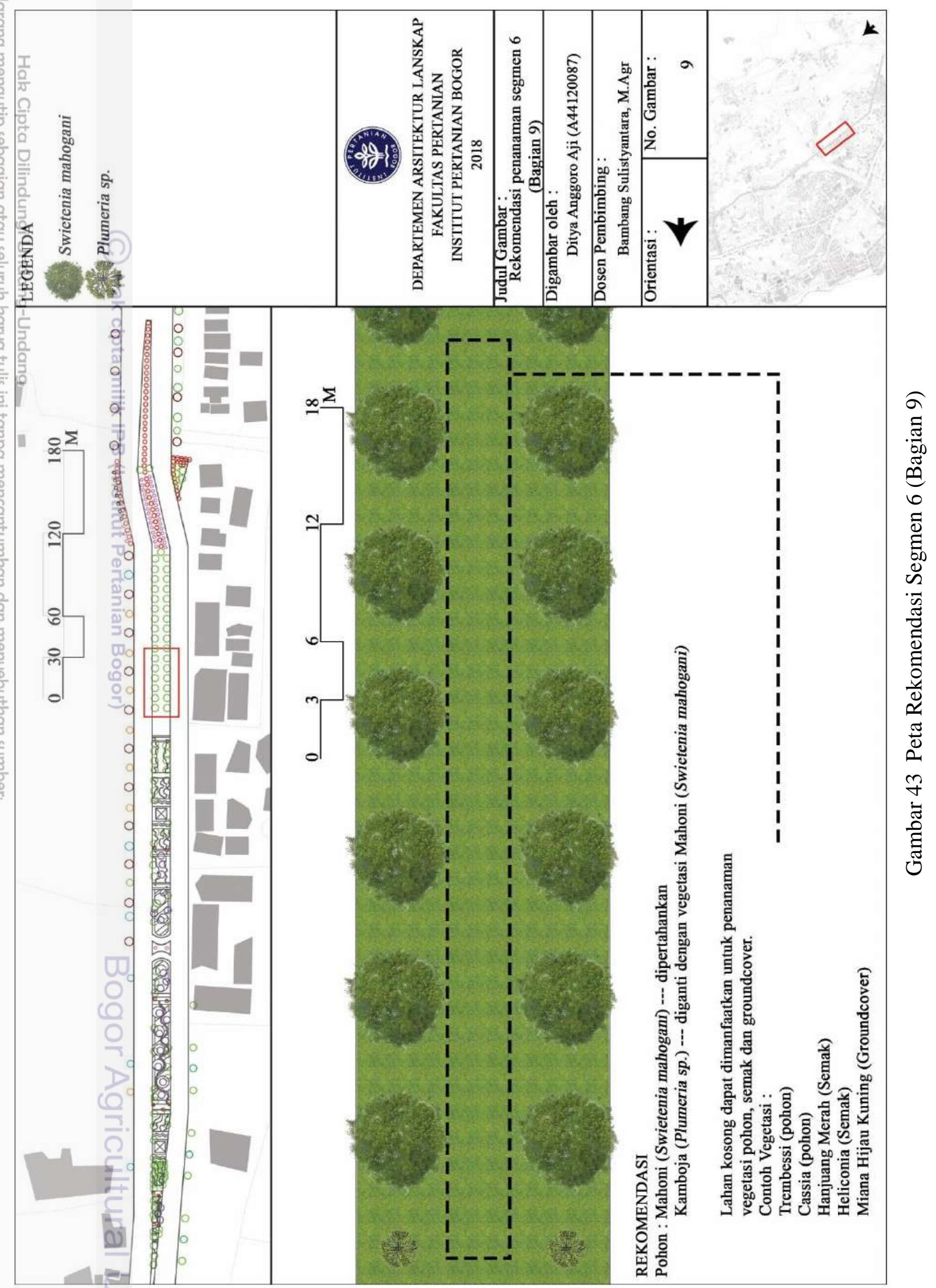




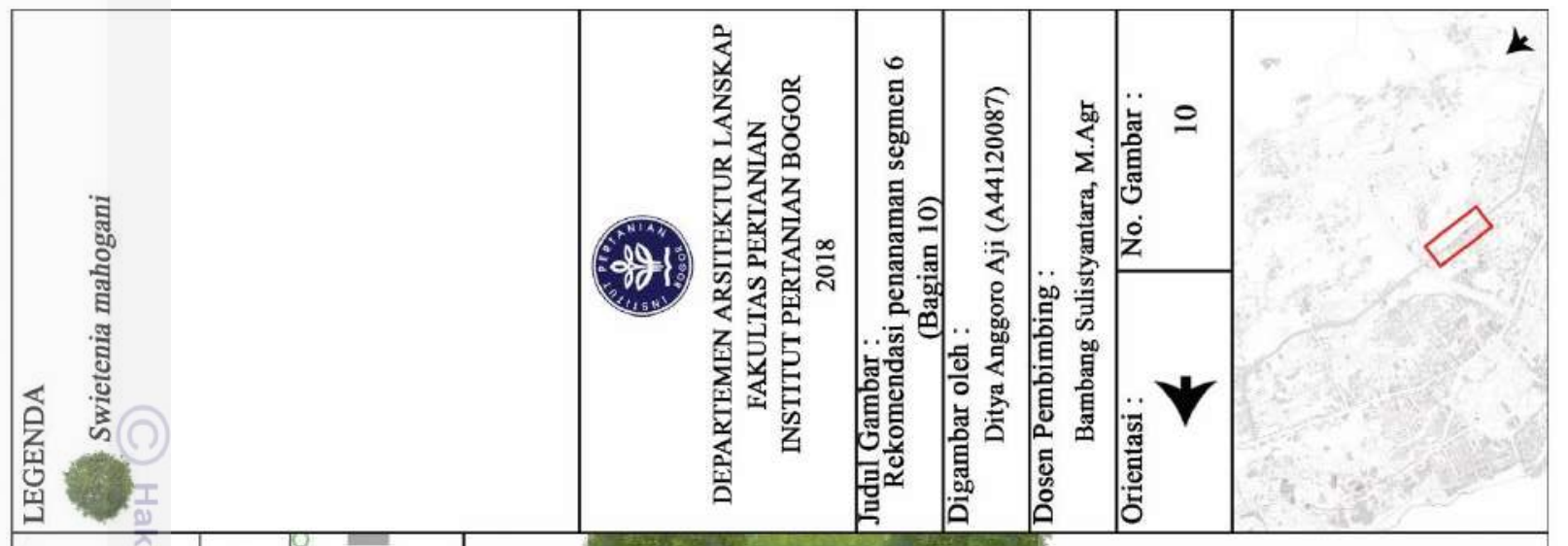

品言言焉

옥을 임

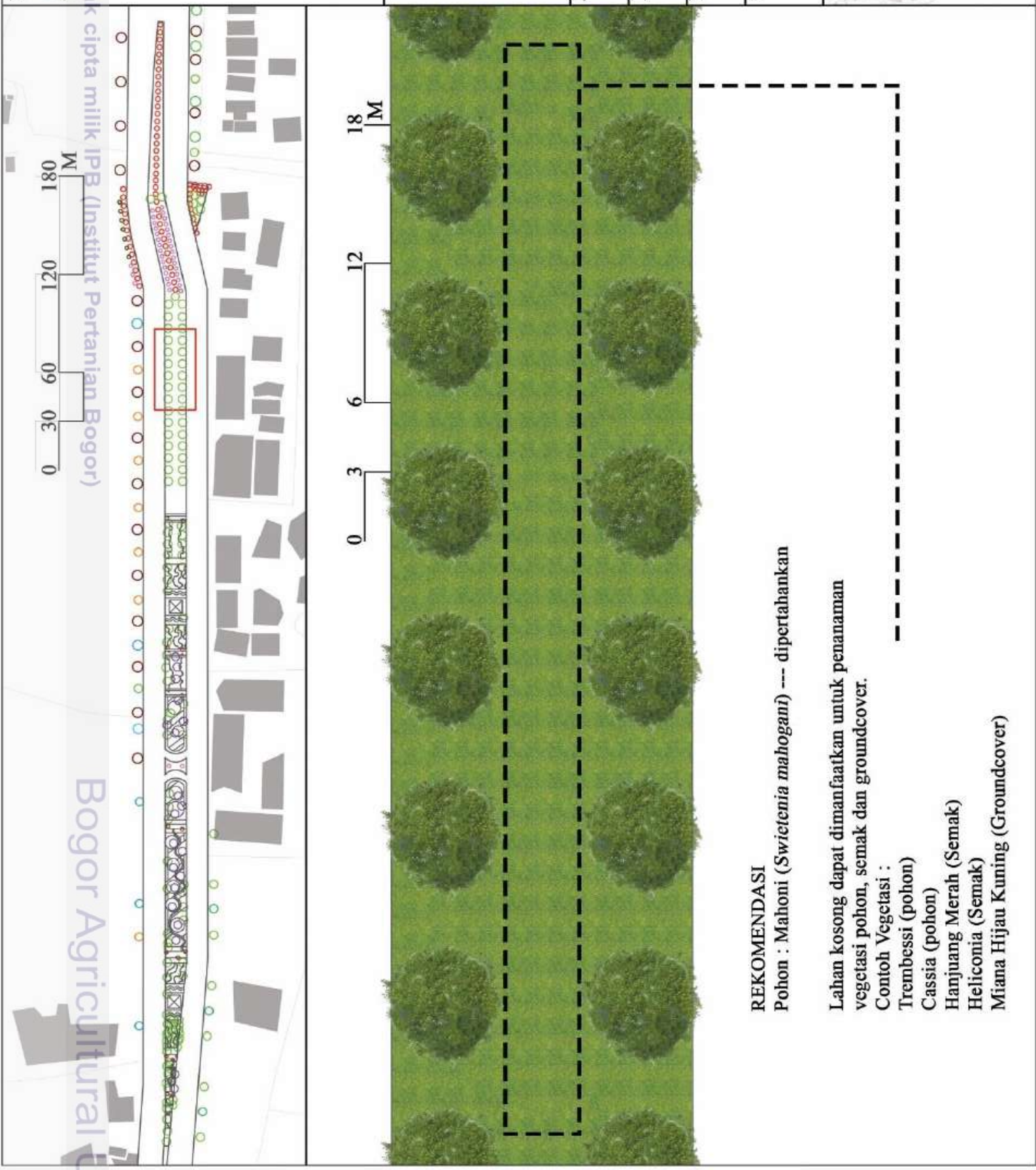

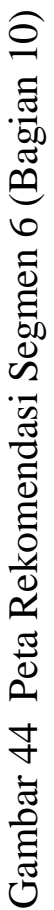




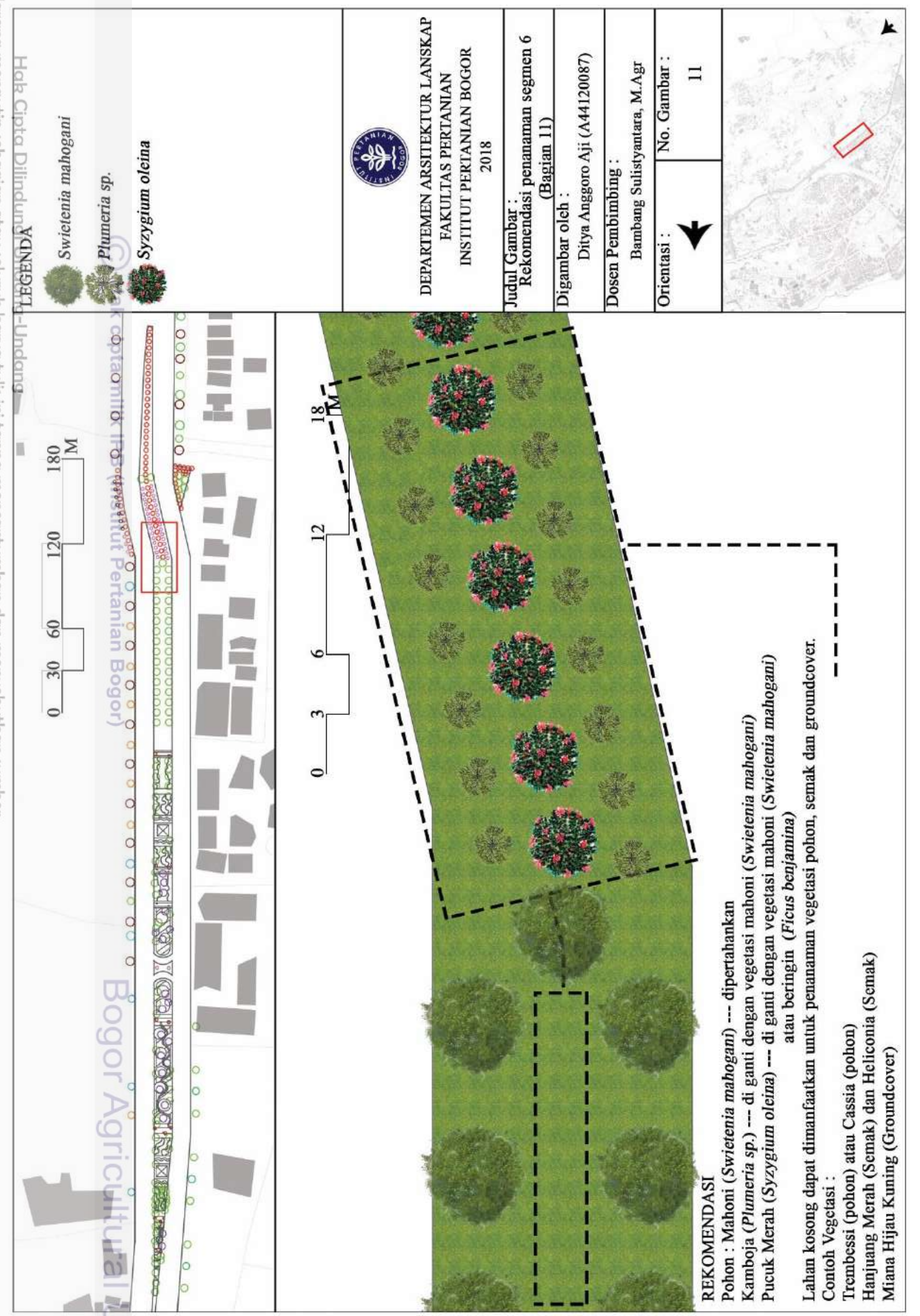

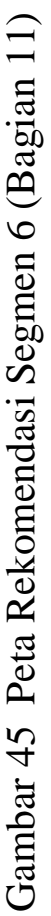




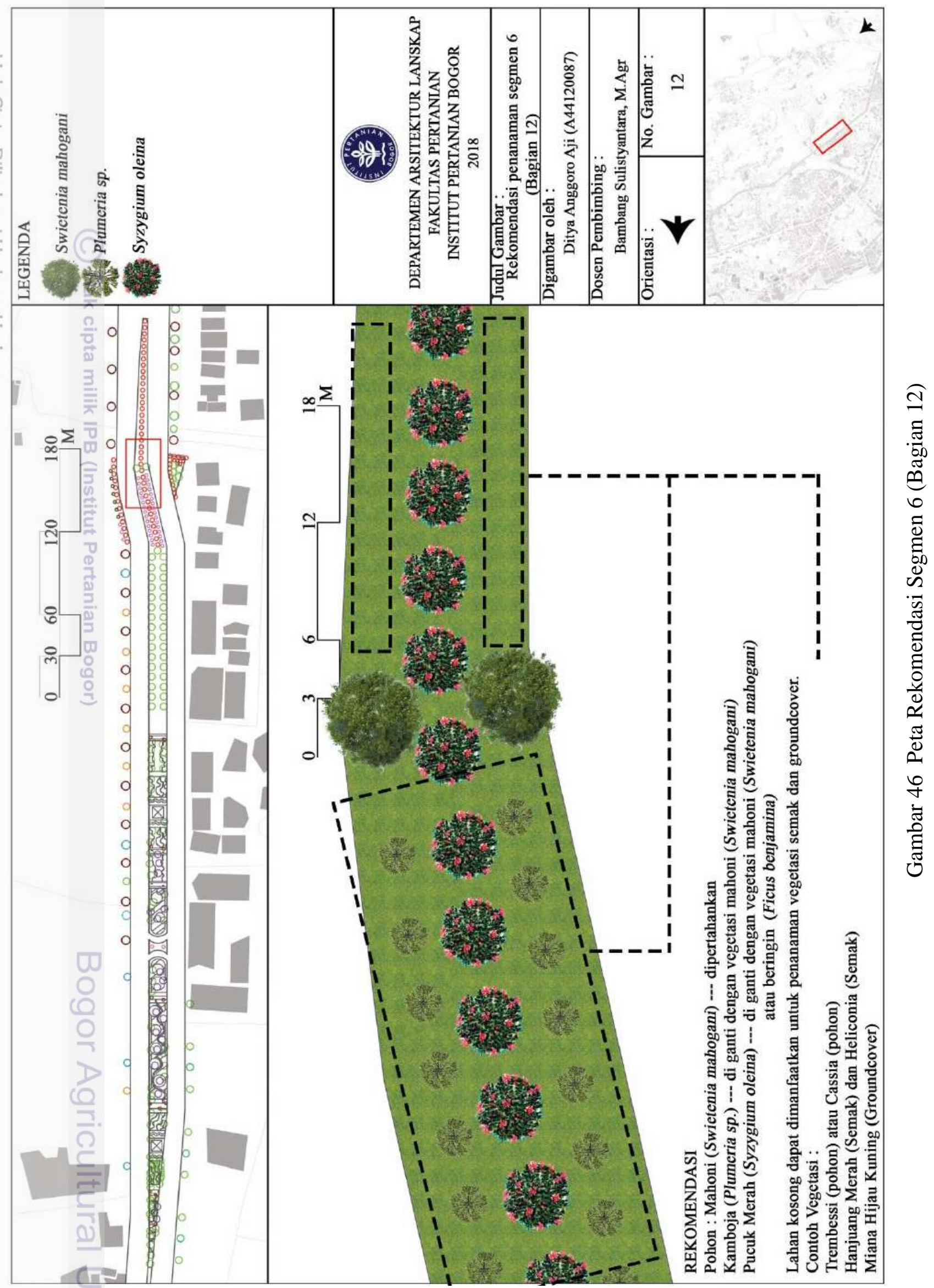




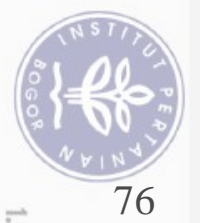

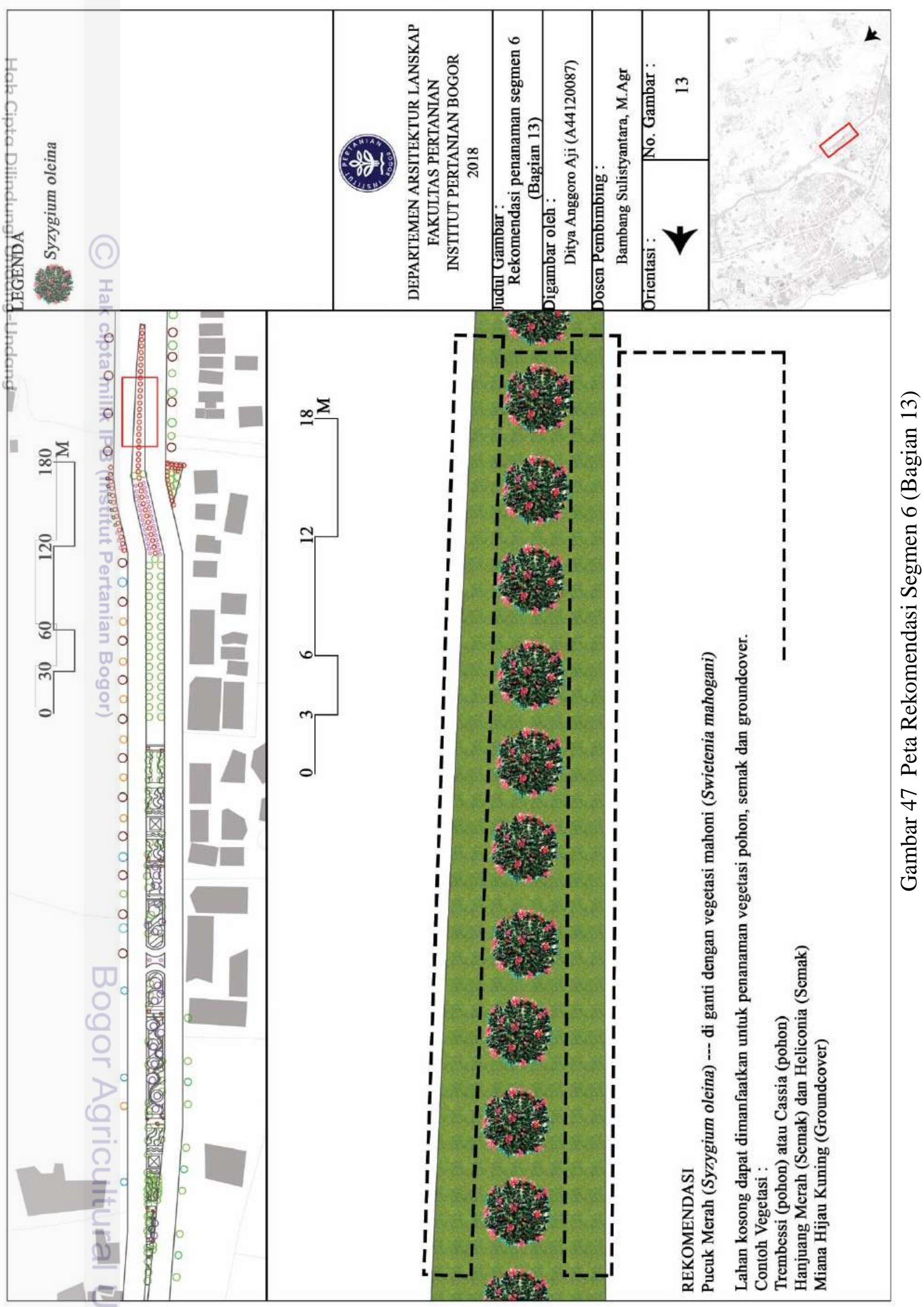




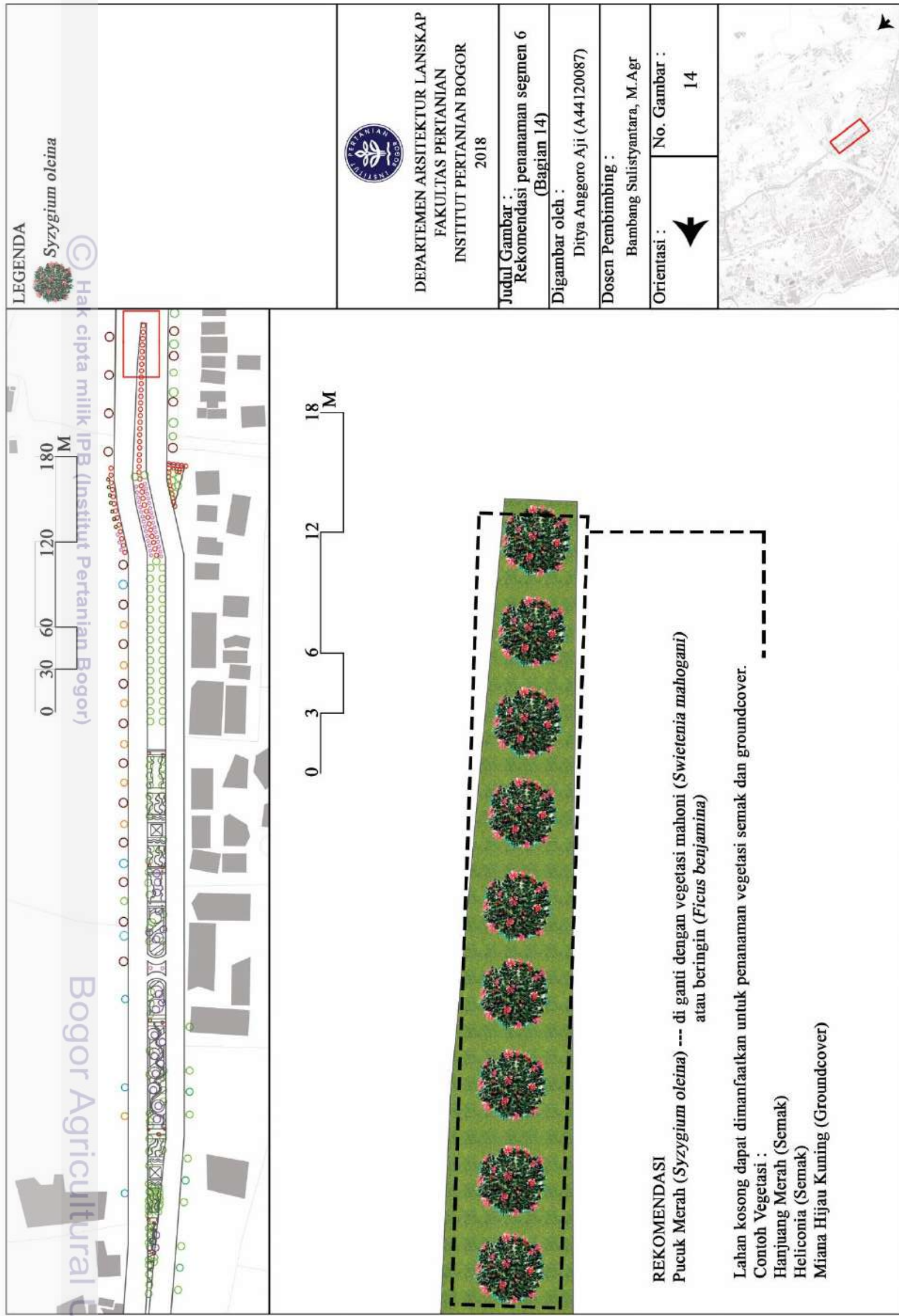

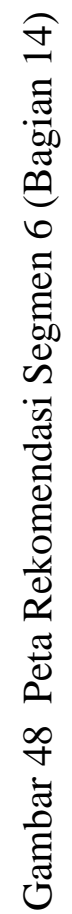




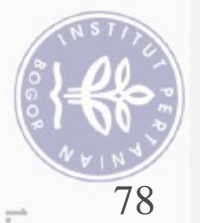

물

브ㄹㅡㅡㄹ 블

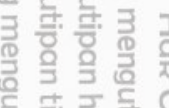

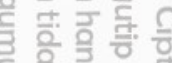

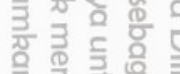

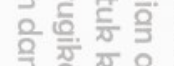

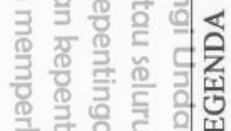

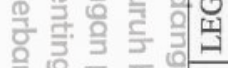

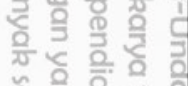

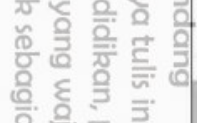

定

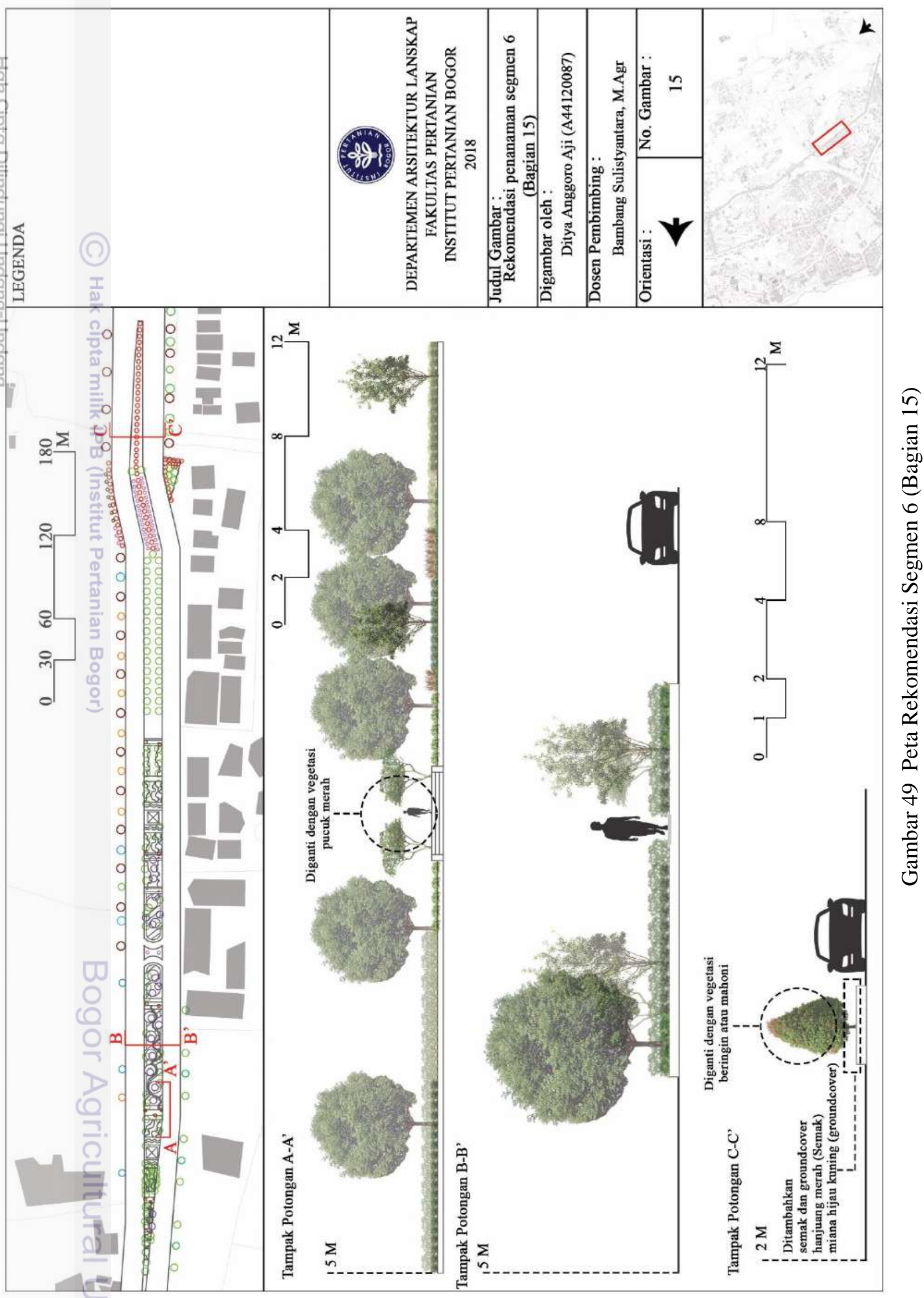




\section{SIMPULAN DAN SARAN}

\section{Simpulan}

Berdasarkan hasil studi didaptkan beberapa simpulan sebagai berikut:

1. Terdapat 27 jenis pohon yang ada di sepanjang Jalan R3 Kota Bogor. Jenis pohon yang memiliki jumlah terbanyak adalah pohon mahoni (Swietenia mahagoni) dengan jumlah 929 pohon. Hasil analisa penelitian menunjukkan bahwa potensi daya serap total emisi CO2 adalah $684,793 \mathrm{~kg} / \mathrm{ha} / \mathrm{jam}$, nilai tersebut lebih rendah dibandingkan dengan total emisi $\mathrm{CO} 2$ yang dihasilkan oleh kendaraan yaitu 4327,206 kg/ha/jam. Sehingga dibutuhkan penanaman vegetasi yang lebih agar dapat mereduksi emisi CO2;

2. Ruang terbuka hijau berupa vegetasi pohon Jalan R3 Kota Bogor belum cukup mereduksi beban emisi $\mathrm{CO} 2$ yang dihasilkan dari kendaraan bermotor dengan sisa emisi yang tidak dapat direduksi sebesar 3.642,413 kg/jam;

3. Hasil evaluasi penilaian untuk fungsi ekologis sebagai penyerap polutan gas menunjukkan bahwa 11 jenis pohon sangat sesuai untuk fungsi penyerap polutan gas dengan luas 87,4 \%. 11 jenis pohon yang sangat sesuai untuk menyerap polutan gas dari hasil penilaian evaluasi di lapang yaitu, dadap merah (Erythrina cristagalli), terung bunga ungu (Solanum melongena), tabebuya kuning (Tabebuia rosea), mangga (Mangifera indica), ketapang kencana (Terminalia mantaly), dan kenari (Canarium indicum L.), mahoni (Swietenia mahagoni), pucuk merah (Syzygium oleina), bintaro (Cerbera manghas), biola cantik (Ficus lyrata), dan angsana (Pterocarpus indicus). Jenis pohon mahoni (Swietenia mahagoni), pucuk merah (Syzygium oleina), bintaro (Cerbera manghas), biola cantik (Ficus lyrata), dan angsana (Pterocarpus indicus) merupakan jenis tanaman utama pada jalur hijau jalan ini dan ditanam dalam jumlah banyak pada median serta tepi dengan beberapa lapis tanaman. 11 jenis pohon tersebut menjadi rekomendasi pananaman dan sebaiknya dipertahankan di lapang;

4. Peta rekomendasi pada segmen 6 merupakan hasil rekomendasi akhir. Segmen 6 digunakan sebagai contoh penanaman karena memiliki serapan $\mathrm{CO} 2$ tertinggi yaitu 117,61 kg/ha/jam. Peta rekomendasi segmen 6 berupa replanting untuk meningkatkan kemampuan serapan $\mathrm{CO} 2$ yang dapat diaplikasian pada penanaman jalan lainnya.

\section{Saran}

Saran yang diberikan oleh penulis berdasarkan penelitian yang telah dilakukan sebagai berikut:

1. Hasil studi diharapakan dapat menjadi masukan bagi Dinas Perumahan dan Pemukiman dan dinas-dinas terkait dalam pengembangan lanskap Jalan R3 Kota Bogor untuk tahap selanjutnya;

2. Pendataan jenis vegetasi yang dilakukan oleh Dinas Perumahan dan Pemukiman Kota Bogor sebaiknya dilengkapi dan dilakukan secara rutin, agar keberadaan vegetasi dapat termonitor dengan baik;

3. Penelitian ini diharapakan dapat menggambarkan pentingnya RTH untuk fungsi ekologis sebagai penyerap polutan gas pada lanskap jalan;

4. Dapat dilakukan penelitian lanjutan untuk mengetahui kefektifan penyerapan polutan gas jenis lainnya selain CO2 pada Jalan R3 Kota Bogor. 


\section{DAFTAR PUSTAKA}

Adiastari R. 2010. Kajian mengenai kemampuan ruang terbuka hijau dalam menyerap emisi karbon di kota Surabaya. Tugas Akhir. Institut Teknologi Sebelas Nopember. Surabaya.

Badan Pusat Statistik. 2016. Kecamatan Bogor Timur Dalam Angka. Kota Bogor.

Badan Pusat Statistik. 2016. Kecamatan Bogor Utara Dalam Angka. Kota Bogor.

Badan Pusat Statistik. 2017. Jawa Barat Dalam Angka. Jawa Barat.

Bennett JH dan AC Hill. 1973. Absorption of Gaseous Air Pollutants by A Standardized Plant Canopy. Journal of The Air Pollution Control Association Vol. 23.

Benson JF dan Roe MH. 2000. Landscape and Sustainability. London (UK): Spon Press.

[BMKG]. Badan Meteorologi Klimatologi dan Geofisika. 2016. Kota Bogor.

Carpenter PL, T Walker dan F Law. 1975. Plants in the Landscape. San Fransisco (US): W. H. Freeman and Company.

Desianti A. 2011. Evaluasi Fungsi Ekologis Jalur Hijau Jalan Kawasan Sentul City [Skripsi]. Bogor (ID): Institut Pertanian Bogor.

Departemen Kehutanan. Handbook of Indonesian Forestry. 2005, Jakarta.

Dinas Lingkungan Hidup. 2016. Laporan Akhir Pengujian dan Analisa Kualitas Udara Ambien Kota Bogor Tahun. Bogor

Direktorat Jenderal Bina Marga. 1996. Tata Cara Perencanaan Teknik Lanskap Jalan. Departemen Pekerjaan Umum.

Direktorat Jenderal Penataan Ruang. 2008. Peraturan Menteri Pekerjaan Umum Nomor 5 Tahun 2008 tentang Pedoman Penyediaan dan Pemanfaatan Ruang Terbuka Hijau di Kawasan Perkotaan. Jakarta. 62 hal.

Duryatmo dan Sardi. 2008. Jasa Pohon Sepanjang Hayat. Trubus Edisi Khusus HUT Ke-63 RI.

Echols, John M dan Hassan S. 2000. Kamus Inggris - Indonesia. Jakarta: PT Gramedia.

Fandeli, Chafid dan Muhammad. 2009. Prinsip-Prinsip Dasar Mengkonservasi Lanskap. Yogyakarta: UGM press.

Fardiaz S. 1992. Polusi Air dan Udara. Yogyakarta (ID): Kanisius.

Frick H dan B Suskiyatno. 2007. Dasar-Dasar Arsitektur Ekologis: Konsep Pembangunan Berkelanjutan dan Ramah Lingkungan. Yogyakarta (ID): Kanisius

Grey GW dan Deneke FJ. 1978. Urban forestry. New York (US): John Wiley and Sons, Inc.

Hajderi A dan L Bozo. 2014. Air Pollution from Vehicles and Their Effect on Human Health in Urban Areas. International Jurnal of Engineering Science and Innovative Tecnology (IJESIT) Vol. 3/5/2014: 3.

Harris CW dan Dines NT. 1988. Time-Saver Standards for Landscape Architecture: Design and Construction Data. USA: McGraw Hill Inc.

Hidayat IW. 2008. Evaluasi Jalur Hijau Jalan Sebagai Penyangga Lingkungan Sekitarnya dan Keselamatan Pengguna Jalan Bebas Hambatan Jagorawi [Tesis]. Bogor (ID): Institut Pertanian Bogor. 
Irwan ZD. 2008. Tantangan Lingkungan dan Lansekap Hutan Kota. Jakarta (ID): PT Bumi Aksara.

Jinca M. 2009. Pencemaran udara karbonmonoksida dan Nitrogenoksida akibat kendaraan bermotor pada ruas jalan padat lalu lintas di kota Makasar. Simposium. Makasar.

Nasrullah N, S Gandanegara, H Suharsono, M Wungkar dan A Gunawan. 2000. Pengukuran Serapan Polutan Gas NO2 pada Tanaman Tipe Pohon, Semak dan Penutup Tanah dengan Menggunakan Gas NO2 Bertanda ${ }^{15} \mathrm{~N}$. Risalah Pertemuan Ilmiah Penelitian dan Pengembangan Teknologi Isotop dan Radiasi. Jakarta. 181 hal.

Odum EP. 1959. Fundamentals of Ecology. Phildelphia (US): W.B. Saunders Company.

Patra AD, N Nasrullah dan EL Sisworo. 2004. Kemampuan Berbagai Jenis Tanaman Menyerap Gas Pencemar Udara $\left(\mathrm{NO}_{2}\right)$. Risalah Seminar Hasil Penelitian dan Pengembangan Aplikasi Isotop dan Radiasi. Jakarta.

Pemerintah Republik Indonesia. 2004. Undang-Undang Republik Indonesia Nomor 13 tahun 1980 tentang Jalan. Jakarta. 17 hal.

Pemerintah Republik Indonesia. 2004. Undang-Undang Republik Indonesia Nomor 38 tahun 2004 tentang Jalan. Jakarta. 81 hal.

Pemerintah Republik Indonesia. 2007. Undang-Undang Republik Indonesia Nomor 26 tahun 2007 tentang Penataan Ruang. Jakarta. 107 hal.

Pemerintah Republik Indonesia. 2008. Peraturan Menteri Pekerjaan Umum Nomor 05 tahun 2008 tentang Pedoman Penyediaan dan Pemanfaaatan Ruang Terbuka Hijau di Kawasan Perkotaan. Jakarta. 34 hal

Rosanti D. 2011. Morfologi Tumbuhan. Jakarta: Erlangga.

Schomaker ME, et al. 2007. Crown-Condition Classification: A Guide to Data Collection and Analysis. United States (US): Department of Agriculture.

Simonds JO. 1983. Landscape Architecture. New York (US): McGraw-Hill Book Company.

Singh SK, Rao DN, Agrawal M, Pandey J, Narayan D. 1991. Air Pollution Tolerance Index of Plant. J Environ Mgmt, 32: 45-55.

Strauss W dan SJ Mainwaring. 1984. Air Pollution. Edward Arnold.

Steiner F. 2016. Opportunities for Urban Ecology in Community and Regional Planning. California (UK): Oxford University Press.

Sutejo M. 2002. Pupuk dan Cara Pemupukan. Jakarta: Rineka Cipta.

Tinambunan R. 2006. Analisis kebutuhan ruang terbuka hijau di Kota Pekanbaru. Tesis. Institut Pertanian Bogor. Bogor.

Udayana C. 2004. Toleransi Spesies Pohon Tepi Jalan Terhadap Pencemaran Udara di Simpang Susun Jakarta (Jakarta Interchange) Cawang, Jaktim [Tesis]. Sekolah Pascasarjana Institut Pertanian Bogor. Tidak dipublikasikan.

Vitasari D. 2004. Evaluasi Tata Hijau Jalan pada Tiga Jalan Kawasan Pemukiman Besar di Kabupaten Bogor, Jawa Barat [Skripsi]. Departemen Budidaya Pertanian, Fakultas Pertanian, Institut Pertanian Bogor. Tidak dipublikasikan.

Wardhana WA. 2001. Dampak Pencemaran Lingkungan. Yogyakarta (ID): Penerbit Andi. 


\section{LAMPIRAN}

Lampiran 1 Jenis, Letak, dan Jumlah Pohon pada Jalur Hijau Jalan R3 Kota Bogor

\begin{tabular}{|c|c|c|c|c|c|c|}
\hline \multirow{2}{*}{ No } & \multirow{2}{*}{ Nama Latin } & \multirow{2}{*}{ Nama Lokal } & \multirow{2}{*}{ Family } & \multicolumn{2}{|c|}{ Letak } & \multirow[t]{2}{*}{ Jumlah } \\
\hline & & & & Tepi & Median & \\
\hline 1 & Araucaria heteropyllo & a Cemara Norfolk & Araucariaceae & & v & 20 \\
\hline 2 & $\begin{array}{l}\text { Artocarpus } \\
\text { heterophyllus }\end{array}$ & Nangka & Moraceae & $v$ & & 1 \\
\hline 3 & Canarium indicum $L$. & Kenari & Burseraceae & $\mathrm{v}$ & $\mathrm{v}$ & 12 \\
\hline 4 & Cerbera manghas & Bintaro & Apocynaceae & v & $v$ & 171 \\
\hline 5 & Erythrina cristagalli & Dadap merah & Fabaceae & v & v & 49 \\
\hline 6 & Fieus benjamina & Beringin & Moraceae & $v$ & $v$ & 87 \\
\hline 7 & Ficus lyrata & Biola Cantik & Moraceae & v & v & 96 \\
\hline 8 & $\begin{array}{l}\text { Leucaena } \\
\text { leucocephala }\end{array}$ & Pete cina & Fabaceae & v & $v$ & 24 \\
\hline 9 & Livistona chinensis & Palem kipas & Arecaceae & & $\mathrm{v}$ & 72 \\
\hline 10 & Mangifera indica & Mangga & Anacardiaceae & $\mathrm{v}$ & $\mathrm{v}$ & 43 \\
\hline 11 & Mimusops elengi & Tanjung & Sapotaceae & v & & 8 \\
\hline 12 & Morinda citrifolia & Mengkudu & Rubiaceae & & v & 1 \\
\hline 13 & Pinus merkusii & Pinus & Pinaceae & $v$ & $\mathrm{v}$ & 1 \\
\hline 14 & Plümeria sp. & Kamboja & Apocynaceae & v & v & 98 \\
\hline 15 & Polyathea longifolia & Glodogan tiang & Annonaceae & v & & 6 \\
\hline 16 & Psidium guajava & Jambu Klutuk & Myrtaceae & & $v$ & 4 \\
\hline 17 & Pterocarpus indicus & Angsana & Fabaceae & $\mathrm{v}$ & $\mathrm{v}$ & 72 \\
\hline 18 & Roystonea regia & Palem raja & Arecaceae & $\mathrm{v}$ & & 16 \\
\hline 19 & Solanum melongena & $\begin{array}{l}\text { Terung bunga } \\
\text { ungu }\end{array}$ & Solanaceae & & $\mathrm{v}$ & 24 \\
\hline 20 & $\begin{array}{l}\text { Spathodea } \\
\text { campanulata }\end{array}$ & Kecrutan & Bignoniaceae & $v$ & & 4 \\
\hline 21 & Swietenia mahogani & Mahoni & Meliaceae & $\mathrm{v}$ & $\mathrm{v}$ & 929 \\
\hline 22 & Syzygium aqueum & Jambu air & Myrtaceae & & $v$ & 5 \\
\hline 23 & Syzygium oleina & Pucuk Merah & Myrtaceae & $v$ & $v$ & 823 \\
\hline 24 & Tabebuia rosea & Tabebuya kuning & Bignoniaceae & $v$ & $v$ & 45 \\
\hline 25 & Tectona grandis & Jati & Lamiaceae & & v & 4 \\
\hline 26 & Terminalia mantaly & $\begin{array}{l}\text { Ketapang } \\
\text { kencana }\end{array}$ & Combretaceae & v & $v$ & 11 \\
\hline 27 & Veitchia merilii & Palem putri & Arecaceae & v & $v$ & 108 \\
\hline & 0 & Total Veget & tasi & & & 2374 \\
\hline
\end{tabular}

Sumber: Survey lapang, Dinas Perumahan dan Permukiman Kota Bogor 


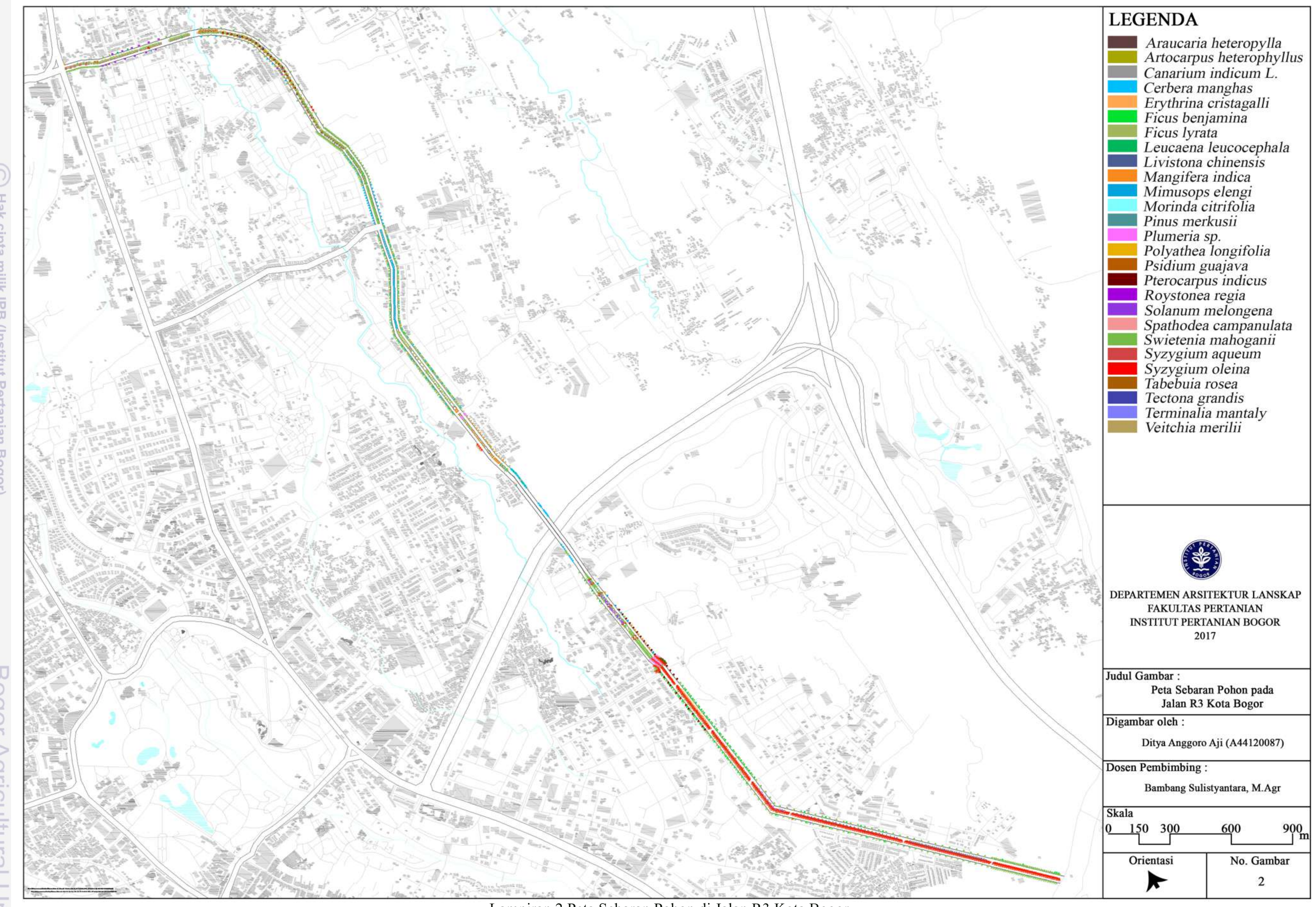

Lampiran 2 Peta Sebaran Pohon di Jalan R3 Kota Bogor 
Lampiran 3 Elemen Tanaman Pada Jalur Hijau Jalan R3 Kota Bogor

\begin{tabular}{|c|c|c|c|c|}
\hline No & Nama latin & Nama lokal & Family & Jenis \\
\hline \multicolumn{5}{|c|}{ Groundcover } \\
\hline 1 & $\begin{array}{l}\text { Alternanthera } \\
\text { ficoidea }\end{array}$ & Bayam merah & Amaranthaceae & Groundcover \\
\hline 2 & Barleria prionitis $L$. & Landep & Acanthaceae & Groundcover \\
\hline 3 & Ophiopogon jaburan & Lili paris putih & Liliacaeae & Groundcover \\
\hline 4 & Chrysanthemum sp & Seruni jalar & Asteraceae & Groundcover \\
\hline 5 & Coleus blumei & Miana hijau kuning & Lamiaceae & Groundcover \\
\hline 6 & Lantana sp. & $\begin{array}{l}\text { Lantana bunga } \\
\text { ungu }\end{array}$ & Verbenaceae & Groundcover \\
\hline 7 & $\begin{array}{l}\text { Ophiopoghon } \\
\text { variegata }\end{array}$ & Alang alang putih & Asparagaceae & Groundcover \\
\hline 8 & Pandanus pygmaeus & Pandan kuning & Pandanaceae & Groundcover \\
\hline$\frac{\pi}{\bar{\alpha}} 9$ & $\begin{array}{l}\text { Ruellia } \\
\text { malacosperma dwarf }\end{array}$ & Rurelia ungu & Acanthaceae & Groundcover \\
\hline \multicolumn{5}{|c|}{ Semak } \\
\hline 1 & Alpinia sp. & Honje belang & Zingiberaceae & Semak sedang \\
\hline 2 & Bougenvillea sp & Bougenville & Nyctaginaceae & Semak tinggi \\
\hline 3 & Canna indica & Kanna presiden & Cannaceae & Semak rendah \\
\hline 4 & Canna lily 'zebra' & Kanna zebra & Cannaceae & Semak rendah \\
\hline 5 & Cordyline terminalis & Hanjuang merah & Agavaceae & Semak tinggi \\
\hline 6 & Crinum $s p$ & Bakung & Amaryllidaceae & Semak rendah \\
\hline 7 & Dianella variegata & Dianella & Asphodelaceae & Semak rendah \\
\hline 8 & Ixora dwarf & Soka mini putih & Rubiaceae & Semak rendah \\
\hline 8 & Neomarica longifolia & Iris kuning & Iridaceae & Semak rendah \\
\hline 9 & Osmoxylon lineare & Aralia laba laba & Araliaceae & Semak sedang \\
\hline 10 & $\begin{array}{l}\text { Pseuderanthemum } \\
\text { reticulatum }\end{array}$ & Melati jepang & Apocynaceae & Semak rendah \\
\hline 11 & $\begin{array}{l}\text { Tabernaemontana } \\
\text { dwarf }\end{array}$ & $\begin{array}{l}\text { Melati tarbenia } \\
\text { mini }\end{array}$ & Apocynaceae & Semak rendah \\
\hline \multicolumn{5}{|c|}{ Perdu } \\
\hline 1 & Codiaeum sp. & Puring & Euphorbiaceae & Perdu rendah \\
\hline$\sigma_{2}$ & $\begin{array}{l}\text { Dracaena reflexa } \\
\text { variegate }\end{array}$ & Drasena & Agavaceae & Perdu tinggi \\
\hline 3 & Heleconia sp. & Heleconia & Heliconiaceae & Perdu rendah \\
\hline \multicolumn{5}{|c|}{ Rumput } \\
\hline 1 & $\begin{array}{l}\text { Axonopus } \\
\text { compressus }\end{array}$ & Rumput gajah & Poaceae & Rumput \\
\hline
\end{tabular}

Sumber : Survey lapang, Dinas Perumahan dan Permukiman Kota Bogor 
Lampiran 4 Jenis Tanaman yang Berpotensi Menyerap NO2

\begin{tabular}{|c|c|c|c|}
\hline No & Nama Latin & Nama Lokal & Serapan $15 \mathrm{~N}(\mu \mathrm{g} / \mathrm{gr})$ \\
\hline \multicolumn{4}{|c|}{ Pohon } \\
\hline $\mathbf{A}$ & Serapan tinggi ( $>30 \mu \mathrm{g} / \mathrm{gr})$ & & \\
\hline 1 & Erythrina variegata & Dadap kuning & 68.31 \\
\hline 2 & Cananga odorata & Kenanga & 46.70 \\
\hline 3 & Gnetum gnemon & Melinjo & 44.17 \\
\hline 4 & Calliandra surinamensis & Kaliandra & 41.01 \\
\hline 5 & Delonix regia & Flamboyant & 38.58 \\
\hline 6 & Caesalpinia pulcherrima & Kembang merak & 36.99 \\
\hline 7 & Diallium indum & Asam kranji & 36.69 \\
\hline 8 & Ceiba pentandra & Kapuk & 35.66 \\
\hline 9 & Bixa orellana & Galinggem & 35.56 \\
\hline 10 & Brownea capitella & Bunga lampion & 35.39 \\
\hline 11 & Samanea saman & Kihujan & 35.37 \\
\hline 12 & Michelia campaka & Cempaka & 33.92 \\
\hline 13 & Psidium guajava & Jambu biji & 30.80 \\
\hline 14 & Cassia multijuga & Hujan mas & 30.52 \\
\hline 15 & Artocarpus integra & Nangka & 30.35 \\
\hline B & \multicolumn{3}{|l|}{ Serapan sedang $(15-30 \mu \mathrm{g} / \mathrm{gr})$} \\
\hline 1 & Casuarina equisetifolia & Cemara angin & 28.79 \\
\hline 2 & Khaya senegalensis & Pohon kaya & 28.61 \\
\hline 3 & Terminalia catappa & Ketapang & 27.02 \\
\hline 4 & Spathodea campanulata & Kecrutan & 26.88 \\
\hline 5 & Bauhinia purpurea & Bunga kupu-kupu & 26.30 \\
\hline 6 & Pterocarpus indicus & Angsana & 25.44 \\
\hline 7 & Arundinaria sp. & Bambu jepang & 25.33 \\
\hline 8 & Mangifera indica & Mangga & 25.12 \\
\hline 9 & Saraca indica & Asoka & 23.94 \\
\hline & Eucalyptus alba & Kayu putih & 23.65 \\
\hline & Cassia biflora & Kasia golden & 22.85 \\
\hline & Areca cathecu & Pinang jambe & 22.62 \\
\hline & Cassia sp. & Ayoga & 21.91 \\
\hline & Barringtonia asiatica & Keben & 21.10 \\
\hline & Lansium domesticum & Duku & 20.28 \\
\hline & Polyaltia fragrans & Glodogan bulat & 20.15 \\
\hline 17 & Mangifera caesia & Kemang & 19.72 \\
\hline & Cinnamomum burmanii & Kayu manis merah & 19.71 \\
\hline 19 & Caryota mitis & Palm ekor ikan & 18.89 \\
\hline 20 & Veitchia merilii & Palem putri & 18.66 \\
\hline 21 & Elaeis guineensis & Kelapa sawit & 17.81 \\
\hline
\end{tabular}


Lampiran 4 Jenis Tanaman yang Berpotensi Menyerap NO2 (Lanjutan)

\begin{tabular}{|c|c|c|c|}
\hline No & Nama Latin & Nama Lokal & Serapan $15 \mathrm{~N}(\mu \mathrm{g} / \mathrm{gr})$ \\
\hline 22 & Casuarina sumatrana & Cemara balon & 17.71 \\
\hline 23 & Schefflera actinophylla & Wali songo & 16.87 \\
\hline 24 & Mimusoph elengi & Tanjung & 16.41 \\
\hline 25 & Cocos nucifera capitata & Kelapa gading & 16.41 \\
\hline $\mathrm{C}$ & Serapan rendah $(<15 \mu \mathrm{g} / \mathrm{gr})$ & & \\
\hline 1 & Agathis dammara & Damar & 14.84 \\
\hline 2 & Cocos nucifera & Kelapa & 14.48 \\
\hline 3 & Durio zibetinus & Durian & 14.49 \\
\hline 4 & Cinnamomum zeylanicum & Kayu manis hijau & 13.06 \\
\hline 5 & Juniperus sinensis & Cemara tiang & 13.06 \\
\hline 6 & Nephelium lappaceum & Rambutan & 12.44 \\
\hline 7 & Acacia auriculiformis & Akasia & 12.39 \\
\hline 8 & Nephelium longanum & Lengkeng & 12.35 \\
\hline 9 & Laucaena glauca & Lamtoro & 12.20 \\
\hline 10 & Roystonea regia & Palem raja & 11.74 \\
\hline 11 & Dillenia philipinensis & Sempur & 11.03 \\
\hline 12 & Livistona rotundifolia & Palem sadeng & 10.60 \\
\hline 13 & Ficus benjamina & Beringin & 9.63 \\
\hline 14 & Cassia siamea & Johar & 8.82 \\
\hline 15 & Ficus elastic & Beringin karet & 8.62 \\
\hline 16 & Podocarpus nerifolius & Kiputri & 8.62 \\
\hline 17 & Shorea leprosula & Meranti & 8.26 \\
\hline 18 & Myristica fragrans & Pala & 8.10 \\
\hline 19 & Cyrtostachis lakka & Palm merah & 7.97 \\
\hline 20 & Cupressus papuana & Cemara papua & 7.80 \\
\hline 21 & Cyanometra cauliflora & Nam-nam & 7.31 \\
\hline 22 & Canarium communae & Kenari & 6.21 \\
\hline 23 & Lagerstromia loudonii & Bungur & 6.13 \\
\hline 024 & Manilkara kauki & Sawo kecik & 5.18 \\
\hline 25 & Phyllostachys sulphurea & Bambu kuning & 5.11 \\
\hline 26 & Araucaria excelsa & Cemara norflok & 4.76 \\
\hline 27 & Mascarena lagenicaulis & Palem botol & 4.38 \\
\hline 28 & Polyaltia longifolia & Glodogan tiang & 3.61 \\
\hline 29 & Felicium decipiens & Kerai paying & 3.46 \\
\hline 30 & Phyticosperma macarthurii & Palem hijau & 2.81 \\
\hline 31 & Thuja orientalis & Cemara kipas & 1.44 \\
\hline$=32$ & Acacia mangium & Akasia mangium & 0.28 \\
\hline
\end{tabular}


Lampiran 4 Jenis Tanaman yang Berpotensi Menyerap NO2 (Lanjutan)

\begin{tabular}{|c|c|c|c|}
\hline No & Nama Latin & Nama Lokal & Serapan $15 \mathrm{~N}(\mu \mathrm{g} / \mathrm{gr})$ \\
\hline \multicolumn{4}{|c|}{ Semak } \\
\hline A & Serapan tinggi (> $30 \mu \mathrm{g} / \mathrm{gr})$ & & \\
\hline 1 & Jacobinia carnea & Lollipop merah & 100.02 \\
\hline 2 & Malphigia sp. & Kihujan & 93.28 \\
\hline 3 & Acalypha wielkesiana & Akalipa merah & 64.80 \\
\hline 4 & Pachystachis lutea & Lollipop kuning & 61.70 \\
\hline 5 & Mussaenda erythrophylla & Nusa indah merah & 53.53 \\
\hline 6 & Notophanax scultellarium & Daun mangkokan & 46.07 \\
\hline 7 & Bougenvillea glabra & Bogenvil merah & 45.44 \\
\hline 8 & Gardenia augusta & Kaca piring & 45.29 \\
\hline 9 & Coleus blumei & Miana & 41.70 \\
\hline 10 & $\bar{C}$ Cordyline terminalis & Hanjuang merah & 36.34 \\
\hline 11 & Rhododendron indicum & Azalea & 35.95 \\
\hline 12 & Lantana camara & Lantana ungu & 35.14 \\
\hline 13 & Acalypha wilkesiana & Akalipa hijau-putih & 31.24 \\
\hline B & Serapan sedang $(15-30 \mu \mathrm{g} / \mathrm{gr})$ & & \\
\hline 1 & Scindapsus aureus & Sirih belanda & 25.63 \\
\hline 2 & Alpinia purpurata & Lengkuas merah & 24.55 \\
\hline 3 & Txora javanica & Ixora daun besar & 23.86 \\
\hline 4 & Notophanax sarcofagus & Kedondong laut & 20.95 \\
\hline 5 & Crinum asiaticum & Bakung & 20.03 \\
\hline 6 & Nerium oleander & Bunga mentega & 20.03 \\
\hline 7 & Chrysalidocarpus lutescens & Palem kuning & 19.48 \\
\hline 8 & Canna indica & Kana & 18.91 \\
\hline 9 & Iresine herbstii & Bayam merah & 18.86 \\
\hline 10 & Caladium hortulanum & Keladi putih & 18.50 \\
\hline 11 & Dracaena fragrans & Drasena & 17.74 \\
\hline 12 & Allamanda cathartica & Alamanda & 17.63 \\
\hline 13 & Mirabilis jalapa & Bunga pukul empat & 17.51 \\
\hline 14 & Heliconia psittacorum & Helikonia merah & 18.86 \\
\hline 15 & Plutea indica & Beluntas & 16.99 \\
\hline 16 & Cycas revolute & Sikas & 16.28 \\
\hline 17 & Gendarusa vulgaris & Gendarusa & 16.27 \\
\hline 18 & Arundinaria pumila & Bambu pangkas & 15.97 \\
\hline 19 & Costus speciosus & Pacing & 15.27 \\
\hline 20 & Acalypha macrophylla & Teh-tehan & 15.10 \\
\hline C & Serapan rendah $(<15 \mu \mathrm{g} / \mathrm{gr})$ & & \\
\hline 1 & Carmona retusa & Serut & 13.67 \\
\hline 2 & Heliconia sp. & Helikonia oranye & 13.60 \\
\hline
\end{tabular}


Lampiran 4 Jenis Tanaman yang Berpotensi Menyerap NO2 (Lanjutan)

\begin{tabular}{|c|c|c|c|}
\hline No & Nama Latin & Nama Lokal & Serapan $15 \mathrm{~N}(\mu \mathrm{g} / \mathrm{gr})$ \\
\hline 3 & Clerodendron thomsonae & Nona makan sirih & 13.58 \\
\hline 4 & Vinca rosea & Tapak dara & 12.41 \\
\hline 5 & Plumbago indica & Plumbago & 12.39 \\
\hline 6 & Licuala grandis & Palem kol & 11.93 \\
\hline 7 & Ficus repens & Dolar-doalran & 11.76 \\
\hline (7) 8 & Mussaendah alba & Nusa indah putih & 10.90 \\
\hline 9 & Agave sisalana & Agave hijau & 9.99 \\
\hline 10 & Pleomele variegata & Pleomele & 8.56 \\
\hline 11 & Passiflora cocinea & Passiflora & 8.46 \\
\hline 12 & Bougainvillea spectabilis & Bougenvil oranye & 7.89 \\
\hline 13 & Hippeastrum amarylis & Amarilis & 7.71 \\
\hline चे 14 & Agave americana & Agave kuning & 7.61 \\
\hline 15 & Aglaonema nitidum & Sri rejeki & 7.59 \\
\hline 16 & Caladium bicolor & Keladi hias & 7.47 \\
\hline 17 & Stephanotis floribunda & Stepanot & 7.44 \\
\hline 18 & Heliconia rosrata & Pisang hias & 6.83 \\
\hline 19 & Rosa chinensis & Mawar & 6.60 \\
\hline 20 & Cycas rumphii & Pakis haji & 6.22 \\
\hline 21 & Malphigia coccigyera & Mirten & 5.53 \\
\hline 22 & Duranta repens & Duranta kuning & 4.48 \\
\hline 23 & Excoecaria bicolor & Sambang darah & 4.77 \\
\hline 24 & Murraya paniculata & Kemuning & 4.56 \\
\hline 25 & Salvia splendens & Salvia merah & 4.23 \\
\hline 26 & Duranta variegata & Terang bulan & 4.11 \\
\hline 27 & Ixora chinensis & Ixora daun kecil & 4.11 \\
\hline 28 & Rhapis excelsa & Palem wregu & 3.40 \\
\hline 29 & Phyllanthus niruri & Cendrawasih & 2.57 \\
\hline 30 & Hibiscus rosa-sinensis & Kembang sepatu & 2.03 \\
\hline 31 & Eugenia uniflora & Sianto & 1.97 \\
\hline \multicolumn{4}{|c|}{ Rumput } \\
\hline $\mathbf{A}$ & Serapan sedang $(15-30 \mu \mathrm{g} / \mathrm{gr})$ & & \\
\hline 1 & Alternanthera ficoides & Kriminil merah & 24.06 \\
\hline$>2$ & Zoysia matrella & Rumput manila & 22.58 \\
\hline 3 & Rhoeo discolor & Adam hawa & 18.81 \\
\hline B & Serapan rendah $(<15 \mu \mathrm{g} / \mathrm{gr})$ & & \\
\hline$\frac{E}{\square} 1$ & Cynodon dactylon & Rumput kawat & 13.94 \\
\hline$=2$ & Axonopus compressus & Rumput paetan & 13.31 \\
\hline (1) 3 & Althernantera amoena & Kriminil putih & 9.96 \\
\hline-4 & Cuphea macrophylla & Taiwan beauty & 9.72 \\
\hline
\end{tabular}


Lampiran 4 Jenis Tanaman yang Berpotensi Menyerap NO2 (Lanjutan)

\begin{tabular}{cllc}
\hline No & Nama Latin & Nama Lokal & Serapan $15 \mathrm{~N}(\mu \mathrm{g} / \mathrm{gr})$ \\
\hline 5 & Chlorophytum comosum & Clorophytum hijau & 9.50 \\
6 & Philea cardierei & Mutiara & 7.13 \\
7 & Chlorophytum bachestii & Chlorophytum putih & 4.56 \\
8 & Ophiopogon jaburan & Lili paris putih & 2.38 \\
\hline
\end{tabular}

Sumber : Nasrullah, Gandanegara, Suharsono, Wungkar dan Gunawan (2000)

Lampiran 5 Daya Serap Pohon Terhadap Karbon Dioksida

\begin{tabular}{cllcc}
\hline No & Nama Latin & Nama Lokal & $\begin{array}{c}\text { Daya serap CO2 } \\
(\mathrm{kg} / \text { pohon/thn) }\end{array}$ & Tingkat Serapan \\
\hline 1 & Samanea saman & Trembesi & 28488,39 & Sangat tinggi \\
2 & Cassia sp. & Cassia & 5295,47 & Sangat tinggi \\
3 & Canagium odoratum & Kenanga & 756,59 & Tinggi \\
4 & Dysoxylum excelsum & Pingku & 720,49 & Tinggi \\
5 & Ficus benjamina & Beringin & 535,90 & Tinggi \\
6 & Felicium decipiens & Kerai payung & 404,83 & Agak Tinggi \\
7 & Pometia pinnata & Matoa & 329,76 & Agak Tinggi \\
8 & Swietenia mahoganii & Mahoni & 295,73 & Agak Tinggi \\
9 & Adenanthera pavonina & Saga & 221,18 & Agak Tinggi \\
10 & Lagerstromia speciosa & Bungur & 160,14 & Agak Tinggi \\
11 & Tectona grandis & Jati & 135,27 & Sedang \\
12 & Arthocarpus & Nangka & 126,51 & Sedang \\
13 & Cassia grandis & Johar & 116,25 & Sedang \\
14 & Annona muricata & Sirsak & 75,29 & Sedang \\
15 & Schima wallichii & Puspa & 63,31 & Sedang \\
16 & Acacia auriculiformis & Akasia & 48,68 & Sedang \\
17 & Delonix regia & Flamboyant & 42,20 & Sedang \\
18 & Manilkara kauki & Sawo kecik & 36,19 & Sedang \\
19 & Mimusoph elengi & Tanjung & 34,29 & Sedang \\
20 & Caesalpinia & Bunga merak & 30,95 & Sedang \\
21 & Dillenia retusa & Sempur & 24,24 & Sedang \\
22 & Khaya anthotheca & Khaya & 21,90 & Sedang \\
23 & Tntsia bijuga & Merbau pantai & 19,25 & Sedang \\
24 & Acacia mangium & Akasia & 15,19 & Sedang \\
25 & Pterocarpus indicus & Angsana & 11,12 & Sangat rendah \\
26 & Pithecelobium dulce & Asam kranji & 8,48 & Sangat rendah \\
27 & Maniltoa grandiflora & Saputangan & 8,26 & Sangat rendah \\
\hline Erythrina cristagalli & Dadap merah & 4,55 & Sangat rendah \\
\hline Nephelium lappaceum & Rambutan & 2,19 & Sangat rendah \\
\hline & & & \\
\hline
\end{tabular}


Lampiran 5 Daya Serap Pohon Terhadap Karbon Dioksida (Lanjutan)

\begin{tabular}{lllcc}
\hline No & Nama Latin & Nama Lokal & $\begin{array}{c}\text { Daya serap CO2 } \\
\text { (kg/pohon/thn) }\end{array}$ & Tingkat Serapan \\
\hline 30 & Tamarindus indica & Asam & 1,49 & Sangat rendah \\
31 & Coompasia excelsa & Kempas & 0,20 & Sangat rendah \\
\hline
\end{tabular}

Sumber : Duryatmo dan Sardi (2008) 
믐 우을

을

흐을 흘

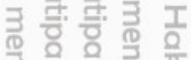

宩类

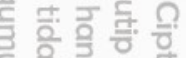

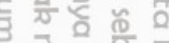

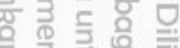

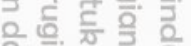

券衣

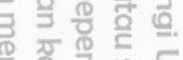

年 $\frac{\pi}{2}$ 를

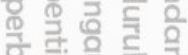

言要

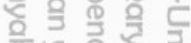

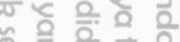

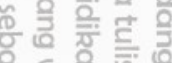

है.

을

웅 西焉

(อ)

苑

홀 율

즉 흘

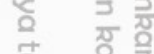

产 党

כ.

을 흘 궁

奉 के

일

든

웅

更

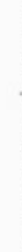




\section{RIWAYAT HIDUP}

Penulis lahir dengan nama Ditya Anggoro Aji di Bogor pada 18 Oktober 1994. Penulis merupakan anak terakhir dari Agung Wradsongko dan Indria Prawitasari dan merupakan adik dari Nindya Ayu Wradsari.

Penulis memulai pendidikan formal sekolah dasar pada tahun 2000 di Sekolah Dasar Negeri Polisi 4 Bogor dan berhasil menyelesaikan proses belajar pada tahun 2006. Di tahun yang sama, penulis melanjutkan pendidikan ke Sekolah Menengah Pertama Negeri 18 Bogor. Penulis kemudian melanjutkan Pendidikan ke Sekolah Menengah Atas Bina Insani pada tahun 2009 dan lulus pada tahun 2012.

Penulis melanjutkan pendidikan tinggi ke Institut Pertanian Bogor melalui jalur Undangan Tulis Mandiri (UTM). Penulis menjalankan tahun pertama di universitas sebagai mahasiswa Tingkat Persiapan Bersama (TPB). Pada tahun kedua, penulis menjadi mahasiswa pada mayor Arsitektur Lanskap. Selama menjadi mahasiswa, penulis turut aktif dalam beberapa kepanitiaan acara kampus dan departemen. Tahun keempat dan kelima penulis aktif menjadi salah satu anggota divisi pengembangan sumberdaya manusia (PSDM) yang merupakan bagian dari kepengurusan Himpunan Mahasiswa Arsitektur Lanskap IPB (HIMASKAP). 